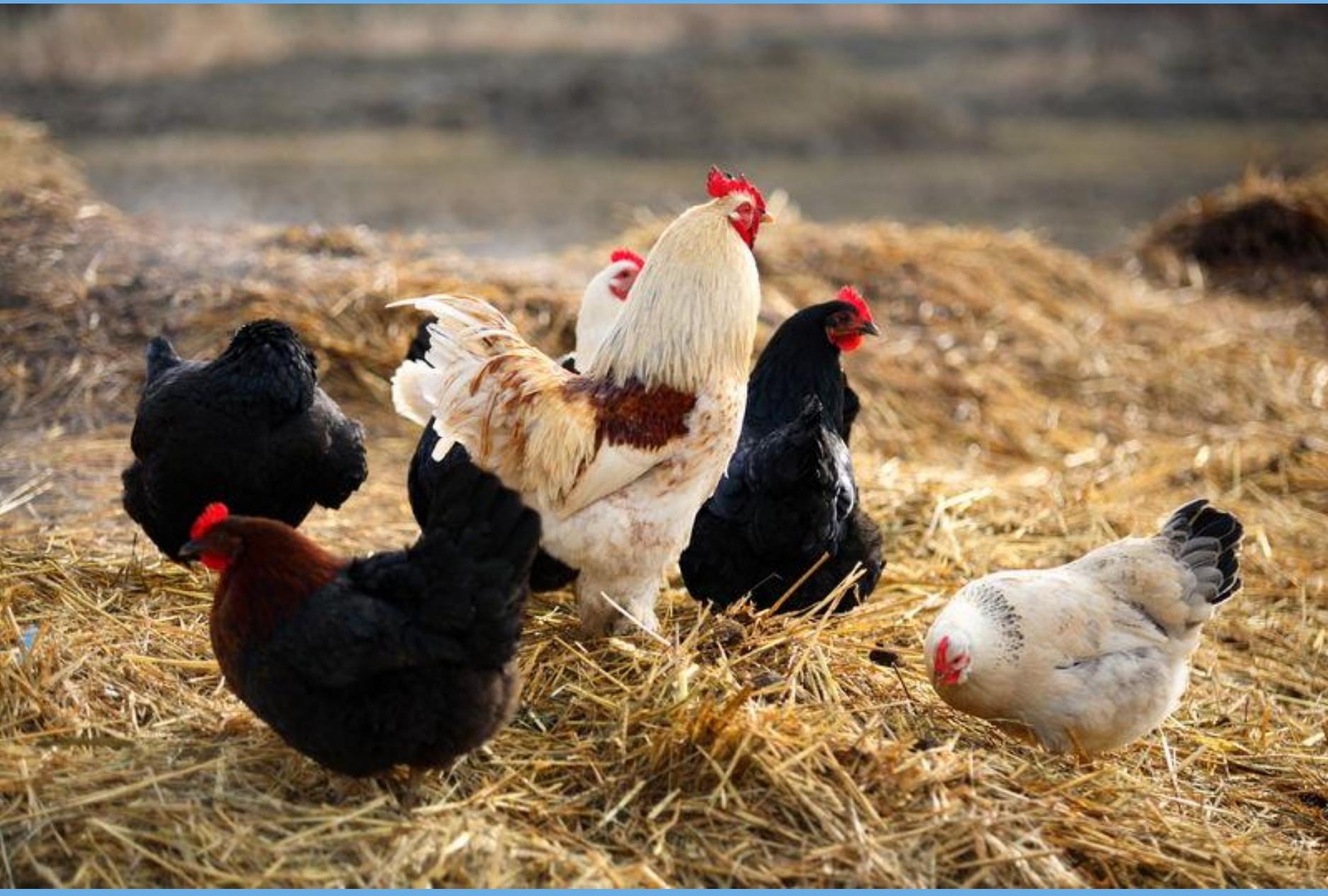

\title{
Wageningen Bioveterinary Research
}

Omgevingstransmissie van aviaire influenza virus door de lucht via wilde watervogels naar commercieel gehouden pluimvee - met een focus op transmissie vanuit HPAIV-gecontamineerde uitwerpselen van wilde watervogels via de lucht of vanuit een aerosol geproduceerd door uitademen of proesten van HPAIV-besmette wilde watervogels

Editor: Armin R.W. Elbers

Augustus 2021

DOI $10.18174 / 556247$ 


\section{Omgevingstransmissie van aviaire inffluenza virus door de lucht via wille watervogels naar commericieel gehouden pluïmvee - met een focus op transmissie vanuit HPAIV-gecontamineerde}

uitwerpselen van wilde watervogels via de lucht of vanuit een aerosol geproduceerd door uitademen of proesten van HPAIV-besmette wilde watervogels

Editor: dr.ir. Armin R.W. Elbers

met bijdragen van

drs. Evelien A. Germeraad, dr. José L. Gonzales, dr. Thomas J. Hagenaars, dr.ir. Clazien J. de Vos en dr.ir. Armin R.W. Elbers

Wageningen Bioveterinary Research

Rapport 2128494

Dit onderzoek is uitgevoerd door Wageningen Bioveterinary Research in het kader van de One-Health for Food (1H4F) PPS "Risico vogelgriep: relatieve rol van insleeproutes en bioveiligheid op en rondom het pluimveebedrijf (LWV 19081)" dat gefinancierd wordt door het Ministerie van L.N.V. en het pluimveebedrijfsleven. 
Omgevingstransmissie van aviaire influenza virus door de lucht via wilde watervogels naar commercieel gehouden pluimvee - met een focus op transmissie vanuit HPAIV-gecontamineerde uitwerpselen van wilde watervogels via de lucht of vanuit een aerosol geproduceerd door uitademen of proesten van HPAIV-besmette wilde watervogels (A.R.W. Elbers, editor)

(C) 2021 Wageningen Bioveterinary Research

Postbus 65, 8200 AB Lelystad, T 03202382 38, E info.bvr@wur.nl, www.wur.nl/bioveterinaryresearch. Wageningen Bioveterinary Research.

Alle rechten voorbehouden. Niets uit deze uitgave mag worden vermenigvuldigd en/of openbaar gemaakt worden door middel van druk, fotokopie, microfilm of op welke wijze dan ook zonder voorafgaande toestemming van de uitgever of auteur. 
Bijdrage van auteurs aan verschillende hoofdstukken

Samenvatting - Armin Elbers

Hoofdstuk 1 Voorwoord - Armin Elbers en Evelien Germeraad

Hoofdstuk 2 Transmissie van AIV - Evelien Germeraad en Armin Elbers

Hoofdstuk 3 Prevalentie van HPAIV in levende wilde vogels

tijdens HPAI-epidemieën - Armin Elbers

Hoofdstuk 4 Hoeveel AIV bevat wilde vogelmest? - Armin Elbers

Hoofdstuk 5 Hoe lang persisteert AIV in de omgeving? - Evelien Germeraad en Jose Gonzales

Hoofdstuk 6 Kan wilde eendenmeststof met aangehecht AIV als stof vervliegen en zichh daardoor via de lucht over relatief grote afstanden verspreiden? - Armin Elbers

Hoofdstuk 7 Aerosol transmissie van influenza A virus - Armin Elbers

Hoofdstuk 8 Wat is de infectieuze dosis van AIV in pluimvee? - Evelien Germeraad en José Gonzales

Hoofdstuk 9 Pluimveehouder redenering "virus is via luchtinlaat binnen gekomen" in perspectief geplaatst - Armin Elbers, Thomas Hagenaars en José Gonzales

Hoofdstuk 10 Semi-kwantitatieve risicoanalyse transmissie van AIV door de lucht van wilde vogel naar pluimveestal - Armin Elbers en Clazien de Vos

Algemene Conclusies - Armin Elbers 



\section{Inhoudsopgave}

$\begin{array}{ll}\text { Samenvatting } & 7\end{array}$

1

$\begin{array}{ll}\text { Voorwoord } & 13\end{array}$

2

Transmissie van AIV

Prevalentie van HPAIV in levende wilde watervogels tijdens HPAI-epidemieën

Kan wilde eendenmeststof met aangehecht AIV als stof vervliegen en zich daardoor via de lucht over relatief grote afstanden verspreiden?

Aerosol transmissie van influenza $A$ virus

Pluimveehouder redenering "virus via luchtinlaat binnen gekomen" in perspectief geplaatst

Semi-kwantitatieve risicoanalyse transmissie van AIV door de lucht van wilde vogel naar pluimveestal

Dankwoord 



\section{Samenvatting}

Wilde watervogels van de orde Anseriformes (Eenden, Ganzen, Zwanen) en Charadriiformes (o.a. Meeuwen, Steltlopers, Sternen, Kluten) zijn het natuurlijk reservoir van aviaire influenza virussen (AIVs). Deze wilde watervogels kunnen een belangrijke rol spelen bij de eerste introductie van het virus in pluimvee, doordat zij AIV uitscheiden wanneer zij geïnfecteerd zijn. AIV vermeerdert in respiratoire (luchtweg), intestinale (darm), renale (nier) en/of reproductieorganen van vogels. Vogels scheiden het virus respiratoir en/of cloacaal uit, dus via secreta (vloeibare afscheiding) uit de neus, mond, conjunctiva (oogslijmvlies) en via excreta (uitwerpselen) uit de cloaca. Hoog-pathogene aviaire influenza virussen (HPAIV) kunnen ook vermeerderen in de epidermis (buitenste huidlaag) waardoor deze virussen ook kunnen worden gedetecteerd in veerfollikels en de stuitklier.

AIV uitgescheiden door wilde vogels in de omgeving van pluimveebedrijven creëert de mogelijkheid tot introductie van AIV in pluimveestallen of de uitloop van pluimveebedrijven.

Veldonderzoek in Nederland heeft laten zien dat wilde eenden in de periode oktober - april 's nachts de uitloop van een pluimveebedrijf kunnen bezoeken op zoek naar voedsel waarbij ze ook in waterplassen in de uitloop zwemmen en daarbij in deze waterplassen kunnen poepen. Kippen die overdag in de uitloop lopen, drinken water uit dergelijke waterplassen, waardoor kippen geïnfecteerd kunnen raken met AIV uitgescheiden in de waterplassen. Delen van uitwerpselen van AIV-geïnfecteerde wilde vogels gedeponeerd in de omgeving van pluimveestallen kunnen worden meegenomen in de pluimveestal doordat zij aan b.v. laarzen, kleren, gereedschappen kunnen hechten, de stal inkomen met beddingmateriaal dat buiten de stal is opgeslagen, of mogelijk aan de vacht of pootjes van ratten en muizen de pluimveestal in worden genomen.

Kritische factoren die een rol kunnen spelen bij de omgevingstransmissie van AIV vanuit wilde vogels naar commercieel gehouden pluimvee door de lucht - met een focus op transmissie vanuit HPAIVgecontamineerde uitwerpselen van wilde watervogels via de lucht of vanuit een aerosol geproduceerd door uitademen of proesten van HPAIV-besmette wilde watervogels - zijn a) de hoeveelheid AIV in wilde vogeluitwerpselen en in aerosolen afkomstig van geïnfecteerde wilde vogels door proesten en uitademen; b) de overleving van AIV in een aerosol na loskomen vanuit een puntbron of overleving van AIV in de tijd na depositie van besmette uitwerpselen in de omgeving, dat onder invloed is van temperatuur, vochtigheid van de mest, luchtvochtigheid, UV-straling, etc.; c) de mate en mogelijkheid dat mest van wilde vogels (droge) stof wordt en dat deze mestdeeltjes vervolgens via de lucht getransporteerd worden in met name de herfst- en winterperiode die meestal gekenmerkt worden door zeer vochtige omstandigheden; d) de minimale virusdosis die nodig is om pluimvee te infecteren.

De focus van deze risicoanalyse voor transmissie vanuit HPAIV-gecontamineerde uitwerpselen van wilde watervogels via de lucht of vanuit een aerosol geproduceerd door uitademen of proesten van HPAIVbesmette wilde watervogels is gekozen vanwege de mogelijke beperking van het risico van deze transmissieroutes via de toepassing van windbreekgaas.

In dit rapport beperken wij ons tot het bundelen van beschikbare literatuur over bovengenoemde kritische factoren tijdens de omgevingstransmissie van HPAIV naar commercieel pluimvee in de stal via de lucht vanuit: a) uitwerpselen van wilde vogels, of b) een aerosol geproduceerd door uitademen of proesten van HPAIV-besmette wilde vogels.

Daarnaast worden de resultaten van veldonderzoek naar de mogelijkheid tot vervliegen van vogelmest gepresenteerd. De gebundelde literatuur en de resultaten van het veldonderzoek zijn belangrijke kennisbouwstenen om een eventuele kwantitatieve risicoanalyse te kunnen uitvoeren: kwantificering van het risico op insleep van HPAIV, gehecht aan vervliegbare meststofdeeltjes van wilde vogels via luchttransport, of vanuit HPAIV in een aerosol. 
Er zijn wellicht andere omgevingtransmissieroutes die theoretisch mogelijk zouden kunnen zijn zoals b.v. mest op een staldak terecht gekomen door overvliegende wilde watervogel(s) dat met regenwater via lekkage van afvoerbuizen in de stal terecht zou kunnen komen (deze route wordt wat nader onderzocht in het andere projectonderdeel van deze PPS), of dat een wilde watervogel in de vlucht een poepje laat dat theoretisch gezien in een ventilatiezijventiel of nokventilator in de stal terecht zou kunnen komen. De kans op de laatste gebeurtenis is naar verwachting afhankelijk van b.v. de uitvoering en ligging van zijventielen en nokventilatie, maar is praktisch gezien onmogelijk te schatten door gebrek aan gegevens van het optreden daarvan.

\section{Prevalentie van HPAIV in levende wilde watervogels tijdens HPAI-epidemieën (hoof́dstuk 3 )}

De prevalentie van HPAIV in levende wilde watervogels tijdens HPAI-epidemieën is een belangrijke eerste bouwsteen, omdat het helemaal aan het begin staat van de keten van mogelijke omgevingstransmissie. Actieve surveillance naar de mate voorkomen van HPAIV bij levende wilde vogels is wereldwijd gestart na de opkomst en pandemische verspreiding van het Aziatische HPAIV subtype H5N1 rond 2005. Voor 2005 werd er slechts sporadisch HPAIV gevonden in wilde vogels. Actieve surveillance van levende wilde vogels is een enorme, en kostbare opgave vanwege het vangen en bemonsteren van zeer grote hoeveelheden wilde vogels om daarin naar verwachting slechts enkele besmette vogels te vinden. Verschillende vogelsoorten kunnen worden besmet met HPAIV, maar het zijn voornamelijk migrerende wilde watervogels (van de orde Anseriformes: eenden, ganzen, zwanen) die een rol spelen bij de lange-afstand verspreiding van het virus. Er zijn een zeer beperkt aantal studies uitgevoerd die een betrouwbare schatting hebben gemaakt van de prevalentie van HPAIV in levende wilde vogels tijdens HPAI-epidemieën: de geschatte gemiddelde prevalentie van HPAIV in levende wilde vogels tijdens een epidemie is ca. 5 per 10.000 wilde watervogels (standaard deviatie: 3 per 10.000 wilde watervogels).

\section{Hoeveel AIV bevat (wilde) eendenmest? (hoofdstuk 4)}

$\mathrm{Er}$ is slechts één experimentele AIV-infectiestudie bekend met eenden, (Anas platyrhynchos) en gedomesticeerde eenden (Cairina moschata), waarin de AIV-gehalten per gram mest zijn gemeten. Na experimentele infectie met $10^{4}$ EID 50 per eend van laag-pathogene aviaire influenza virus (LPAIV) subtype H3N6, scheidden de gedomesticeerde eenden gedurende gemiddeld 6 dagen hoge gehaltes aan virus uit: $10^{7}$ tot $10^{8}$ EID50 per gram mest. Dit betekent dat er voor b.v. zwanen en ganzen dergelijke gegevens ontbreken.

$\mathrm{Er}$ is daarnaast zeer weinig bekend over de frequentie waarmee wilde watervogels faeces uitscheiden, en de hoeveelheid faeces die wordt geproduceerd. Door middel van een veldonderzoek en met gehouden Smienten bij WBVR werd het gemiddelde gewicht van smientenuitwerpselen geschat: gemiddeld 2,23 gram (standaard deviatie: 0,85, range: 0,87 - 4,15 gram). Bij gehouden Smienten bij WBVR werd de uitscheidingsfrequentie van smienten geschat (middels videocamerabewaking): dit was gemiddeld 2 keer per dag in het verblijf op de grond. Echter, smienten scheiden waarschijnlijk de meeste faeces af in het water waarin zij zwemmen. De uitwerpselen in het water zullen geen bijdrage leveren aan het kunnen vervliegen van mest na opdroging op het land. Op internetfora wordt aangegeven dat volwassen (wilde) eenden gemiddeld elke 15 tot 30 minuten mest kunnen uitscheiden, dus dat zou 50 tot 100 keer per 24 uur kunnen zijn. Daarbij moet echter worden opgemerkt dat a) waarschijnlijk ca. $50 \%$ van de mestuitscheidingen zullen plaatsvinden op zwemwater, en dus niet op weiland; b) er een aantal uren per dag wordt gerust/geslapen, en er dan geen mestuitscheiding zal plaats vinden. Alles bij elkaar is een schatting van de gemiddelde mestuitscheidingsfrequentie van wilde eenden onzeker, maar zou ca. 50 keer op het (wei)land kunnen zijn. Uit een veldexperiment (met kunstmatige voeding) met ganzen kwam naar voren dat de gemiddeld mestuitscheidingsfrequentie 7,15 keer per 3 uur (s.e.: 0.2), dat is dus gemiddeld ca. 60 keer per 24 uur. Ook hier geldt dat een deel van de mestuitscheiding zou kunnen plaatsvinden in zwemwater, en dus niet op het (wei)land en dat een deel van de dag wordt gerust/geslapen waarbij er geen mestuitscheiding plaats vindt. Alles bij elkaar is een schatting van de gemiddelde mestuitscheidingsfrequentie van ganzen onzeker, maar zou ca. 50 keer per 24 uur op het (wei)land kunnen 
zijn. Een veldstudie bij Canadese ganzen leverde op dat het gemiddelde gewicht van ganzenkeutels 8,3 gram was.

\section{Hoe lang persisteert AIV in de omgeving? (hoofdstuk 5)}

De persistentie van zowel HPAI als LPAI virus neemt af bij hogere omgevingstemperaturen in alle onderzochte materialen, zoals water, mest, veren, veerolie, verschillende oppervlaktes en sloot/beeksediment.

De persistentie van AI virussen in water wordt beïnvloed door het type water (zoet, brak en zout) en de aan/afwezigheid van micro-organismen. In alle watertypes persisteert LPAI virus langer dan HPAI virus. $\angle P A I$ virus persisteert het langst in zoet water: $\angle P A I$ virussen persisteren in zoet water met microorganismen gemiddeld 60 dagen bij $0^{\circ} \mathrm{C}, 50$ dagen bij $4^{\circ} \mathrm{C}$ en 30 dagen bij $12^{\circ} \mathrm{C}$. HPAI virussen persisteren gemiddeld 45 dagen bij $4^{\circ} \mathrm{C}$ en 30 dagen bij $12^{\circ} \mathrm{C}$ in zoet water met micro-organismen.

In mest van pluimvee persisteert AIV minimaal drie weken bij $4^{\circ} \mathrm{C}$. In veren is het AIV persistenter dan in mest: het virus persisteert minimaal 34 dagen bij $4^{\circ} \mathrm{C}$. Het is belangrijk dat karkassen van dode, met HPAIV-besmette wilde (water)vogels zo spoedig mogelijk na sterfte uit de natuurlijke omgeving worden opgeruimd omdat zij de bron zouden kunnen zijn van losse veren; deze zouden vrij kunnen komen als aaseters aan karkassen eten en mogelijk met de wind naar de omgeving en mogelijk luchtinlaat van pluimveestallen kunnen worden vervoerd. Basale gegevens over de mate waarin dit zou kunnen gebeuren ontbreken, waardoor er geen onderbouwde risicoanalyse kan worden uitgevoerd, het blijft bij theoretische mogelijkheid.

Op de meeste ondergronden persisteert het AIV minder dan 6 dagen bij kamertemperatuur, maar op geaffineerd metaal en glas persisteert HPAIV subtype H5N1 13 dagen bij $4^{\circ} \mathrm{C}$. In (sloot/beek) sediment is AIV nog persistenter dan op andere materialen, d.w.z. minimaal 76 dagen bij $20^{\circ} \mathrm{C}$. Een hoge relatieve luchtvochtigheid verkort de persistentie van AIV op diverse materialen bij lage temperaturen $\left(4^{\circ} \mathrm{C}\right)$, maar er is geen afname van persistentie aangetoond bij $20^{\circ} \mathrm{C}$. De persistentie van AIV die zijn bepaald in experimenten kunnen niet één op één vertaald worden naar de AIV persistentie in natuurlijke situaties. De persistentie van AIV zal in natuurlijke situaties waarschijnlijk korter zijn dan in de experimenten wordt aangetoond door de invloed van temperatuur, vochtigheid van de mest, luchtvochtigheid, UV-straling, etc. .

Kan wille vogelmeststof met aangehecht AIV vervliegen en daardoor via de lucht over relatief grote afstanden verspreiden? (hoofdstuk 6)

Analyse van verschillende HPAIV epidemieën bij gehouden pluimvee toonde aan dat tussen-bedrijfsverspreiding van het virus via de lucht kan hebben plaatsgevonden.

Bij deze epidemieën ging het om grootschalige virusproductie door een groot aantal besmette dieren in een stal. Dat is van een volstrekt andere orde van grootte dan de hypothetische mogelijkheid dat AIV vanuit enkele uitwerpselen van besmette wilde vogels in de omgeving van een pluimveestal - na verstoffing van de uitwerpselen - in de lucht komt en via de luchtinlaat in de stal terecht zou kunnen komen. Om mest een transitie te laten doormaken naar droge stof, waardoor het in potentie kan gaan vervliegen en door de wind kan worden getransporteerd, moet het vochtgehalte zeer sterk afnemen (ca. $10 \%$ of minder). Het vochtgehalte van verse eendenmest en verse kippenmest ligt rond de $75-85 \%$. Gedurende de vogelgriep-risicoperiode (oktober - maart 2020) zijn mestmonsters van Smienten (Anas penelope) en Wilde eenden (Anas plathyrhynchos) verzameld in een veldonderzoek in de Nekkeveldpolder bij Nijkerk en bij stadsvijvers in Harderwijk om het vochtgehalte van de mest te bepalen. De kans op verstoffen van uitwerpselen van smienten en wilde eenden in de vogelgriep-risicoperiode wordt beoordeeld als uiterst onwaarschijnlijk. De klimatologische omstandigheden in deze periode zijn zeer nat bij lage temperaturen en lage zonne-instraling. Onder dergelijke weersomstandigheden zal het vochtgehalte van uitwerpselen, die buiten in de natuur in de omgeving van pluimveestallen liggen, niet noemenswaardig afnemen. De resultaten van het veldonderzoek laten zien dat het vochtgehalte van de smienten- en wilde eendenuitwerpselen in de vogelgriep risicoperiode tussen de 70 tot $90 \%$ blijft. De kans dat AIV, gehecht aan vervliegbare meststofdeeltjes van wilde vogels via luchttransport uit de omgeving, in een pluimveestal terecht zouden kunnen komen, wordt ingeschat als verwaarloosbaar. 


\section{Aerosoll transmissie van influenza $\mathbb{A}$ virus (hoofdstuk 7 )}

Het pad waarlangs ziektetransmissie kan plaatsvinden via een aerosol bestaat uit 3 stappen: a) er moet een aerosol gemaakt worden waarin het agens (in dit geval influenza A virus) aanwezig is, d.w.z. er moet een "ontsnapping" plaatsvinden vanaf een bron; b) het agens moet in de aerosol worden getransporteerd naar vatbare dieren, waarbij het virus lang genoeg moet persisteren in voldoende concentratie tijdens het transport om de infectie over te kunnen brengen; en c) inhalatie van de aerosol door vatbare dieren (het landen van het agens op het doel).

Aviaire influenza virus (AIV) wordt door geïnfecteerde vogels uitgescheiden via de neus, mond, oogslijmvliezen, en cloaca, en aerosolen met daarin AIV kunnen daarbij door geïnfecteerde vogels worden geproduceerd via uitgeademde lucht en proesten.

Er zijn verschillende processen die de concentratie van AIV in aerosolen kunnen verlagen:

- Naarmate de relatieve vochtigheid van de lucht toeneemt, zullen deeltjes in een aerosol groter worden en sneller neerslaan;

- Temperatuur en relatieve vochtigheid (RV) zijn goede voorspeller van overleving en transmissie van AIV: zowel koude $\left(5^{\circ} \mathrm{C}\right)$ als droge condities $(20-35 \% \mathrm{RV})$ bevorderen overleving en transmissie van influenza A virus. Bij een temperatuur van $20{ }^{\circ} \mathrm{C}$ en bij lage $\mathrm{RV}(20-35 \%)$, is transmissie van influenza A virus zeer efficiënt (cavia-model); bij een RV van 50\%, kon er beperkte transmissie worden gemeten; bij $80 \%$ RV kon er geen transmissie meer worden gemeten tussen hokken met cavia's.

- Ultraviolette straling uit zonlicht verlaagd de overleving van AIV.

- Ionisatie van de lucht verlaagd de overleving van AIV.

Ontwikkelde wiskundige modellen om vanuit een puntbron benedenwindse concentraties van levensvatbare micro-organismen in aerosolen te schatten bij dynamische atmosferische condities laten zien dat i) lucht als een sterke verdunningsfactor van het virus optreedt op zijn reis naar een doel; op 30 meter afstand van de puntbron wordt het virus met een factor ca. $10^{5}$ verdund, op een afstand van 50 meter is dit al een verdunningsfactor van ca. $10^{20}$; ii) dat hogere windsnelheid er voor zorgt dat er minder tijd is voor afname in persistentie van het virus tijdens de reis naar het doel; iii) dat als het virus wordt losgelaten bij een puntbron op hoogte (b.v. $200 \mathrm{~m}$ boven de grond), het virus een langere reis kan maken naar het doel in vergelijking met virus dat tussen 10 en $50 \mathrm{~cm}$ boven de grond wordt losgelaten; als het virus dicht bij het grondoppervlak wordt losgelaten zal het op zijn reis vaker neerslaan als gevolg van botsing met objecten als b.v. struiken, grashalmen etc..

Transmissie-experimenten met AIV bij pluimvee laten zien dat aerosol transmissie over korte afstand (10 $-40 \mathrm{~cm}$ ) kan optreden, maar dat de kans op besmetting laag is. Kortom, transmissie van AIV via aerosolen over grotere afstanden wordt ingeschat als een zeer onwaarschijnlijke introductieroute en de kans op transmissie als verwaarloosbaar klein.

\section{Wat is de infectieuze dosis van AIV in pluimvee? (hoofdstuk 8)}

De minimale inoculatie dosis die nodig is voor het indiceren van een infectie is voor HPAI virussen $2 \log _{10}$ $50 \%$ effectieve inoculatie dosis (EID50) in kippen, ganzen en kalkoenen en voor LPAI virussen $2 \log _{10}$ EID $_{50}$ in kippen via respiratoire toedieningsroutes. Over het algemeen geldt: hoe hoger de inoculatie dosis, hoe groter het percentage geïnfecteerde dieren. Echter de minimale, of EID50 verschilt per virus (ook van virussen binnen hetzelfde subtype). HPAI virussen hebben gemiddeld een lagere $50 \%$ effectieve dosis dan LPAI virussen. Dit betekent dat HPAI virussen in staat zijn om met een lagere dosis virus dan LPAI virus, de helft van een koppel succesvol te kunnen infecteren. Kippen hebben t.o.v. andere pluimveesoorten de laagste 50\% effectieve dosis voor HPAI virussen. De data in de kippen lijkt een trend te tonen dat HPAI virussen die geïsoleerd zijn uit pluimvee een lagere $50 \%$ effectieve dosis hebben dan virussen die zijn geïsoleerd uit wilde vogels of de mens. 


\section{Pluimveehouder redenering "virus binnen via luchtinlaat" in perspectief geplaatst (hoofdstuk}

9)

Tijdens de uitbraken met HPAIV subtype H5N8 in 2016, 2017-2018 en 2020 hebben enkele pluimveehouders aangegeven dat verhoogde sterfte bij pluimvee begonnen zou zijn bij - of dicht in de buurt van - de luchtinlaat van de pluimveestal. Voor sommige pluimveehouders is het logisch te denken dat aviaire influenza virus (AI) virus daarom via de luchtinlaat binnen zou zijn gekomen omdat men onwillekeurig een directe relatie legt tussen het optreden van de sterfte en de plaats en tijd waar de sterfte wordt gezien. Tussen de observatie van verhoogde sterfte van pluimvee bij - of dicht in de buurt van - de luchtinlaat en de plaats en tijd waar het virus voor het eerst echt zijn intrede heeft gedaan in de stal bestaat echter geen direct, oorzakelijk verband. De daadwerkelijke virus-introductie in een stal ligt gemiddeld ruim meer dan een week vóór het moment_dat er duidelijk verhoogde sterfte wordt gezien in de stal. Dat betekent ook dat gebeurtenissen - één tot enkele dagen voorafgaande aan de verhoogde sterfte zoals sterke wind of dichte mist die op de stal heeft gestaan aan de kant van luchtinlaat - die pluimveehouders soms noemen als veronderstelde oorzaak, geen oorzakelijke relatie kunnen hebben met de introductie van het virus in de stal. Het is onwaarschijnlijk dat een aantal individuele dieren die bij - of dicht in de buurt van - een luchtinlaat zouden zijn besmet, de besmetting doorgeven aan andere dieren en dat minimaal een week later afzonderlijke besmette dieren weer bij elkaar bij - of dicht in de buurt van een luchtinlaat zouden zijn en daar sterven. Dat is op basis van kansrekening niet logisch gezien het grote tijdsverschil tussen besmetting en het waarnemen van de verhoogde sterfte.

Een, in ons opzicht, aannemelijkere verklaring voor het waarnemen van de start van de verhoogde sterfte bij individuele dieren die zich bevinden bij - of dicht in de buurt van - een luchtinlaat is dat HPAIVgeïnfecteerde dieren merendeels ernstige luchtwegproblemen hebben met ademnood. Het is aannemelijk dat dieren met ademnood op zoek gaan naar verse/frisse lucht, die in grotere mate aanwezig zal zijn bij of dicht in de buurt van - een luchtinlaat, en zich daarom naar deze locaties binnen de stal verplaatsen.

\section{Semi-kwantitatieve risicoanalyse transmissie van (HP)AIV door de lucht van wilde vogel naar pluimveestal (hoofdstuk 10)}

In dit rapport zijn de benodigde bouwstenen voor een eventueel uit te voeren kwantitatieve risicoanalyse bijeen gebracht, gericht op de kwantificering van vermindering van het risico op insleep van (HP)AIV via de lucht, met een focus op mogelijke transmissie via de lucht van:

- (HP)AIV gehecht aan vervliegbare meststofdeeltjes van wilde vogels via luchttransport door de luchtinlaat van een pluimveestal naar vatbaar pluimvee;

- (HP)AIV in een aerosol - met als bron proesten of uitademing van geïnfecteerde wilde vogels - via luchttransport door de luchtinlaat van een pluimveestal naar vatbaar pluimvee.

Om inzicht te krijgen of het zinvol is om een uitgebreide kwantitatieve risicoanalyse uit te voeren, wordt meestal eerst een kwalitatieve of semi-kwantitatieve risicoanalyse uitgevoerd. Voor de semikwantitatieve risicoanalyse zijn flowcharts gemaakt voor bovengenoemde introductieroutes, met daarin de stappen voor beide routes. Op basis van de uitgevoerde semi-kwantitatieve risicoanalyses wordt geconcludeerd dat:

- De orde van grootte van de geschatte dosis van (HP)AIV gehecht aan vervliegbare meststofdeeltjes van wilde watervogels die via luchttransport door de luchtinlaat van een pluimveestal bij vatbaar pluimvee zou kunnen komen is ca. $10^{-9}$ tot $10^{-24}$ EID $_{50}$ (ter illustratie: $10^{-9}$ betekent 1 per miljard), terwijl de minimale inoculatie dosis voor infectie met HPAIV bij pluimvee $10^{2}$ EID $_{50}$ is. De geschatte HPAIV dosis is zo verwaarloosbaar klein dat het niet de moeite waard is om in overweging te worden genomen. Dit betekent ook dat het uitvoeren van een uitgebreide kwantitatieve risicoanalyse geen zin heeft.

- De orde van grootte van de geschatte dosis van (HP)AIV die in een aerosol (door uitgeademde lucht of proesten van een besmette wilde vogels) via luchttransport door de luchtinlaat van een pluimveestal bij vatbaar pluimvee zou kunnen komen ca. $10^{-8}$ tot $10^{-23}$ EID 50 is, terwijl de minimale 
inoculatie dosis voor infectie met HPAIV bij pluimvee $10^{2}$ EID50 is. De geschatte (HP)AIV dosis voor deze introductieroute is dus verwaarloosbaar klein. Daarom is er geen uitgebreide kwantitatieve risicoanalyse uitgevoerd.

\section{Algemene conclusies (hoofdstuk 11)}

- De semi-kwantitatieve risicoanalyse laat zien dat het risico op transport van vogelgriepvirus door de lucht vanuit

a) Vervliegbare wilde watervogelmest in de omgeving van de pluimveestal (zoals grasweiden, verharding rondom de stal);

b) een aerosol geproduceerd door uitademen of proesten van HPAIV-besmette wilde watervogels

die via de luchtinlaat in de pluimveestal zou kunnen komen, als verwaarloosbaar klein moet worden beschouwd. Voor deze mogelijke AIV-introductieroutes zijn er daarom geen wetenschappelijke argumenten om daarvoor een afscherming van de luchtinlaten in de vorm van filters (b.v. een hepafilter of mogelijk windbreekgaas) aan te bevelen.

- Veren van HPAIV-besmette wilde vogels bevatten HPAIV. HPAIV in veren is persistent: het virus persisteert minimaal 34 dagen bij $4^{\circ} \mathrm{C}$ en veel langer bij lagere temperaturen. Veren van HPAIVbesmette wilde vogels zouden vrij kunnen komen als aaseters aan karkassen eten en mogelijk met de wind naar de omgeving en mogelijk door de luchtinlaat van pluimveestallen kunnen worden vervoerd. Basale gegevens over de mate waarin dit zou kunnen gebeuren ontbreken echter. Daarom kan er geen onderbouwde risicoanalyse worden uitgevoerd, het blijft bij een theoretische mogelijkheid (net als overigens een hoop andere mogelijke introductieroutes). Uit voorzorg zou men kunnen aangeven dat het belangrijk is dat karkassen van dode, met HPAIV-besmette wilde (water)vogels zo spoedig mogelijk na sterfte uit de natuurlijke omgeving worden opgeruimd omdat zij de bron zouden kunnen zijn van losse veren. 


\section{Voorwoord}

Er zijn sterke aanwijzingen dat in de periode 2014-2018 migrerende wilde vogels hoog pathogeen aviaire influenza virus (HPAIV) naar Nederland hebben gebracht [Bouwstra et al., 2015; Beerens et al., 2017] en de omgeving rond pluimveestallen mogelijk hebben gecontamineerd. Tijdens de uitbraken met HPAI subtype H5N8 virus in 2016 en 2017-2018 hebben enkele pluimveehouders aangegeven dat verhoogde mortaliteit begonnen zou zijn bij - of in de buurt van - de luchtinlaat van de pluimveestal [Velkers et al., 2017; 2018].

Met de hypothese over het mogelijk binnenkomen van het aviaire influenza virus (AIV) via luchtinlaatopeningen van een stal in het achterhoofd, bedacht pluimveehouder Hazenberg uit Abbega, de eigenaar van een legbedrijf dat in 2016 besmet raakte door HPAI subtype H5N8 virus, een dubbel windbreekgaas dat geplaatst werd voor de luchtinlaatopeningen van de stallen om het risico op de introductie van HPAIV daarmee mogelijk te verkleinen [For farmers, 2018]. Virusdeeltjes zijn zo klein dat windbreekgaas deze niet tegen kunnen houden, maar virusdeeltjes die in mest(stof) zitten of eraan gebonden zijn zouden wel (deels) tegengehouden kunnen worden door het windbreekgaas. Veren die mogelijk los zouden komen van karkassen van dode HPAIV-besmette wilde vogels, aanwezig in de omgeving van pluimveestallen, zouden ook via de lucht bij een luchtinlaat van een pluimveestal kunnen arriveren en daar dan tegen kunnen worden gehouden door windbreekgaas, maar dat kan overigens ook door veel minder fijnmazig gaas. Overigens is het idee van het plaatsen van materialen die de lucht filteren bij de luchtinlaat, bijvoorbeeld luchtfilters, niet nieuw. Verschillende bedrijven hoger in de pluimveepiramide, zoals opfok- en fokbedrijven, gebruiken al een hoge kwaliteit luchtfilters (HEPA-filters) bij de luchtinlaten om diverse infectieuze pluimveedierziektekiemen te weren.

De Gezondheidsdienst voor Dieren (GD) in Deventer heeft in 2018 een eerste experimenteel onderzoek uitgevoerd om de werking van windbreekgaas te testen [de Wit \& de Rond, 2018]. Doel van het onderzoek was om onder geconditioneerde omstandigheden het effect van één of twee lagen windbreekgaas te meten op de - aan meststof gebonden - concentratie laag-pathogene aviaire influenza virus (LPAIV), en te vergelijken met een situatie waarbij de meststofdeeltjes met LPAIV door een luchtinlaat werden getrokken zonder "filterwerking" van windbreekgaas. Conclusie van het onderzoek was dat twee lagen windbreekgaas in staat waren om de aan meststof gebonden LPAIV die via de lucht werden aangevoerd te verlagen met een factor 11 tot 142. Deze resultaten suggereren dat de bevestiging van twee lagen windbreekgaas het risico op de introductie van HPAIV, en mogelijk van andere ziekteverwekkers die zich binden aan meststof, via de luchtinlaat zou kunnen verlagen.

De verwachte risicovermindering van HPAIV-introductie bij het gebruik van windbreekgaas voor de luchtinlaatopeningen zou in de praktijk kunnen afwijken van de verwachting die is gewekt door het resultaat van het experimentele onderzoek van de GD.

Kritische factoren die een rol kunnen spelen bij de omgevingstransmissie van AIV vanuit wilde vogels naar commercieel gehouden pluimvee door de lucht - met een focus op transmissie vanuit HPAIVgecontamineerde uitwerpselen van wilde watervogels via de lucht of vanuit een aerosol geproduceerd door uitademen of proesten van HPAIV-besmette wilde watervogels - zijn a) de hoeveelheid AIV in wilde vogeluitwerpselen en in aerosolen afkomstig van geïnfecteerde wilde vogels door proesten en uitademen; b) de overleving van AIV in een aerosol na loskomen vanuit een puntbron of overleving van AIV in de tijd na depositie van besmette uitwerpselen in de omgeving, dat onder invloed is van temperatuur, vochtigheid van de mest, luchtvochtigheid, UV-straling, etc.; c) de mate en mogelijkheid dat mest van wilde vogels (droge) stof wordt en dat deze mestdeeltjes vervolgens via de lucht getransporteerd worden in met name 
de herfst- en winterperiode die meestal gekenmerkt worden door zeer vochtige omstandigheden; d) de minimale virusdosis die nodig is om pluimvee te infecteren.

De focus van deze risicoanalyse voor transmissie vanuit HPAIV-gecontamineerde uitwerpselen van wilde watervogels via de lucht of vanuit een aerosol geproduceerd door uitademen of proesten van HPAIVbesmette wilde watervogels is gekozen vanwege de mogelijke beperking van het risico van deze transmissieroutes via de toepassing van windbreekgaas.

Het doel van dit rapport is het bundelen van beschikbare literatuur over de bovengenoemde kritische factoren tijdens de omgevingstransmissie van AIV door de lucht. Daarnaast worden de resultaten van het veldonderzoek naar de mogelijkheid tot vervliegen van vogelmest gepresenteerd. De gebundelde literatuur en de resultaten van het veldonderzoek zijn belangrijke kennisbouwstenen om een eventuele kwantitatieve risicoanalyse te kunnen uitvoeren: kwantificering van vermindering van het risico op insleep van HPAIV, gehecht aan vervliegbare meststofdeeltjes van wilde vogels via luchttransport, of vanuit AIV in een aerosol.

\section{Referenties}

Bouwstra, R., et al., Full-Genome Sequence of Influenza A(H5N8) Virus in Poultry Linked to Sequences of Strains from Asia, the Netherlands, 2014. Emerg. Infect. Dis., 2015. 21(5): 872-874.

Beerens, N., et al., Multiple Reassorted Viruses as Cause of Highly Pathogenic Avian Influenza $A(H 5 N 8)$ Virus Epidemic, the Netherlands, 2016. Emerg. Infect. Dis., 2017. 23(12): 1974-1981.

De Wit, S., de Rond, J. Aviaire Influenza en windbreekgaas. Rapport GD Deventer, Dec. 2018.10 pp.

Velkers, F.C., Manders, T.T.M., Beerens, N., Elbers, A.R.W., Bouwstra, R.J., Stegeman, J.A. Vogelgriep in Nederland. Analyse H5N8 uitbraken in 2016. Rapport Fac. Diergeneeskunde, Univ. Utrecht. 63 pp.

Velkers, F.C., Manders, T.T.M., Beerens, N., Elbers, A.R.W., Bouwstra, R.J., Stegeman, J.A. Analyse vogelgriepuitbraken met HPAI H5N6 in Nederland in 2017-2018. Rapport Fac. Diergeneeskunde, Univ. Utrecht. $28 \mathrm{pp}$.

For farmers. Windbreekgaas voor de inlaatopeningen van een leghennenstal. 2018; Beschikbaar vanaf: https://www.forfarmersinnovatiefonds.nl/innovaties/innovaties/windbreekgaas_voor_de_inlaatopenin gen_van_een_leghennenstal.aspx [geraadpleegd op 1 juni 2020]. 


\section{Transmissie van AIV}

Wilde watervogels van de orde Anseriformes en Charadriformes zijn het natuurlijk reservoir van AIV [Stallknecht \& Brown, 2009]. Deze wilde watervogels kunnen een belangrijke rol spelen bij de eerste introductie van het virus in pluimvee, doordat zij AIV uitscheiden wanneer zij geïnfecteerd zijn [Swayne et al., 2020]. De rol van wilde vogels bij de introductie van AIV is aangetoond in 2016 in Nederland tijdens de epidemie met het HPAI H5N8 virus. Honderden geïnfecteerde dode kuifeenden, smienten en andere wilde vogels, zoals zwanen en meeuwen, werden dood gevonden in waterrijke gebieden. Daarnaast raakten acht pluimveebedrijven geïnfecteerd met het HPAIV subtype H5N8. Bij vier van de acht besmette pluimveebedrijven zijn, binnen een afstand van $3 \mathrm{t} / \mathrm{m} 20 \mathrm{~km}$, dode wilde vogels gevonden besmet met HPAIV dat genetisch gerelateerd was aan het virus dat gedetecteerd was op het bedrijf [Beerens et al., 2017]. Echter, het pluimvee werd na de bevestiging van HPAIV infectie op het eerste pluimveebedrijf direct opgehokt waardoor direct contact tussen wilde vogels en pluimvee op de andere geïnfecteerde bedrijven dus niet waarschijnlijk is. Daarom wordt aangenomen dat het virus waarschijnlijk vanuit de gecontamineerde omgeving in de stal terecht is gekomen. Ook in 2017, tijdens de epidemie met het HPAIV subtype H5N6 in Nederland, zijn aanwijzingen gevonden dat het virus dat op de pluimveebedrijven is gedetecteerd zeer waarschijnlijk is geïntroduceerd door wilde vogels. Op één van de HPAIV subtype H5N6 geïnfecteerde pluimveebedrijven is twee dagen na infectie op $9 \mathrm{~km}$ afstand een dode wilde vogel gevonden die geïnfecteerd was met een zeer verwant virus [Beerens et al., 2019]. Daarnaast wijst onderzoek uit dat de HPAIV-besmette pluimveebedrijven in de periode 2014-2018 allen of vrijwel allen besmet geraakt zijn door enkelvoudige introductie van het virus in de stal, niet door besmetting via contacten tussen pluimveebedrijven onderling [Bouwstra et al., 2015; Beerens et al., 2017]. Wilde vogels spelen dus een belangrijke rol in de introductie van AIV in pluimvee en het is aannemelijk dat migrerende wilde vogels een belangrijke rol spelen bij het transport van AIV naar Nederland. Daarentegen hebben wilde vogels na vestiging van het virus nauwelijks aandeel in de verdere verspreiding van het virus in een besmet pluimveekoppel [Swayne et al., 2020].

AIV vermeerdert in respiratoire (luchtweg), intestinale (maag-darm), renale (nier) en/of reproductieorganen van vogels. Vogels scheiden het virus respiratoir en/of cloacaal uit, dus via secreta (vloeibare afscheiding) uit de neus, mond, conjunctiva (oogslijmvlies) en via excreta (uitwerpselen) uit de cloaca. HPAI virussen kunnen ook vermeerderen in de epidermis waardoor deze virussen ook kunnen worden gedetecteerd in veerfollikels en de stuitklier (deze klier produceert vet om het verenkleed te onderhouden) [Swayne et al., 2020]. De mate en duur van de virusuitscheiding is afhankelijk van de diersoort en de pathogeniciteit van het virus. In pluimvee worden HPAIV in hogere concentraties uitgescheiden dan LPAIV. Daarnaast is de virusconcentratie van HPAIV via de respiratoire route hoger dan via de cloacale route. De virusconcentratie van LPAIV is voor pluimvee, met uitzondering van eenden en duiven, ook hoger via de respiratoire route dan via de cloacale route. Kippen scheiden HPAIV gemiddeld 2,5 dagen lang uit terwijl LPAIV gemiddeld 6 dagen worden uitgescheiden. Gedomesticeerde eenden scheiden HPAIV gemiddeld bijna 7 dagen uit. De meeste pluimveesoorten scheiden langer virus uit via de cloaca dan via de luchtwegen [Germeraad et al., 2019]. Ook in wilde vogels is de mate en duur van virusuitscheiding afhankelijk van de diersoort en het virus. Pantin-Jackwood et al. [2016] toonde aan dat de mate en duur van HPAI en LPAI $\mathrm{H} 5$ - en H7-virusuitscheiding in Wilde eenden (Anas platyrhynchos) varieert per virus. De virusuitscheiding van HPAIV piekt gemiddeld rond de twee en vier dagen na infectie. Daarnaast is cloacale uitscheiding minder hoog dan de respiratoire virusuitscheiding. Eenden kunnen tot meer dan 14 dagen virus uitscheiden, waarbij cloacale uitscheiding voor meerdere virussen langer aanhoudt dan de respiratoire uitscheiding [Pantin-Jackwood et al., 2016].

Wanneer besmette wilde vogels virus uitscheiden kunnen zij pluimvee infecteren. Dit kan via direct contact tussen wilde vogels en pluimvee, dus via contact met virus in secreta uit neus, mond, conjunctiva of cloaca. 
Het virus kan ook via indirect contact worden verspreidt, dus via de omgeving die is bezoedeld met AIV door de secreta en excreta van geïnfecteerde vogels. Mest is een belangrijke indirecte transmissieroute: materialen, schoenen, kleding, stalgereedschap, voertuigen, etc. kunnen bezoedeld raken met geïnfecteerde mest en via deze weg kan het virus worden overgedragen naar een (ander) koppel pluimvee [Swayne et al., 2020]. Transmissie van AIV tussen nabijgelegen pluimveebedrijven via de lucht wordt gezien als een mogelijke transmissieroute tijdens een epidemie met grote aantallen besmette pluimveebedrijven, doordat er verschillende studies zijn uitgevoerd die AIV hebben gedetecteerd binnen 45 of 70 meter van een geïnfecteerde pluimveestal [Jonges et al., 2015; Scoizec et al., 2018; Torremorell et al., 2016]. Pluimvee geïnfecteerd met HPAIV kan een grote hoeveelheid virus produceren dat hecht aan stofdeeltjes en dit kan via de lucht door de ventilatie naar binnen de stal getransporteerd worden. Daarnaast schatte Ypma et al. [2012] dat 18\% van de totale transmissie van HPAIV subtype H7N7 tussen de bedrijven gedurende de uitbraak in 2003 in Nederland te associëren was met de windrichting. Een andere transmissieroute van AIV is transmissie via geïnfecteerd water of geïnfecteerde grond in de uitloop. Wilde vogels bezoeken de uitlopen van commerciële pluimveebedrijven, met name als het pluimvee niet buiten is en kunnen dus via secreta en excreta de uitloop besmetten met AIV [Germeraad et al., 2019; Elbers \& Gonzales, 2020]. Water, aanwezig in sloten, vaarten, vennetjes en meren, maar ook in (tijdelijke) waterpoelen in een uitloop, raakt met name geïnfecteerd door de kleine hoeveelheid, maar relatief hoge virusconcentraties via de respiratoire secreta en door de grote hoeveelheid mest die besmet is met een relatief lage virusconcentratie AIV [Swayne et al., 2020]. Tot slot, kan transmissie van AIV ook plaatsvinden via de producten van vogels, zoals eieren en veren. Ondanks dat het niet is aangetoond dat verticale transmissie van AI virus plaats vindt, is HPAIV terug te vinden op de eierschaal en in de vloeistoffen in de eieren [Swayne et al., 2020]. Daarnaast is HPAIV te detecteren in - en te isoleren uit veren [Busquets et al., 2010; Yamamoto et al., 2017]. Onder experimentele omstandigheden, met het voeren van huisvliegen (Musca domestica L.) met vliegenvoer gemengd met $1 \mathrm{~mL}$ HPAI-H5N1 virus (dosis $5 \times 10^{8.5}$ ei lethale dosis (ELD)), werd er aangetoond dat het mogelijk was kippen te infecteren als de kippen een homogenaat van geïnfecteerde vliegen werd gevoerd [Wanaratana et al., 2013]. De vraag blijft dan nog steeds of dit in de praktijk een daadwerkelijke transmissieroute blijkt te zijn. Daarnaast bestaat er een mogelijke rol van muizen en ratten als vectoren voor AIV-transmissie [Velkers et al., 2017]. Voor alle transmissieroutes via de omgeving geldt dat een transmissie pas succesvol is als er voldoende infectieus virus in de omgeving aanwezig is en dat een gevoelig dier er mee in aanraking moet komen.

Om te voorkomen dat een gevoelig dier in aanraking komt met AIV kunnen er bioveiligheidsmaatregelen worden genomen op een bedrijf. Bioveiligheidsmaatregelen vormen een barrière tussen de stal met pluimvee en de buitenomgeving. Dit klinkt simpel, maar is moeilijk om succesvol in de praktijk in te voeren [Racicot et al., 2011]. Bioveiligheid is de eerste lijn van verdediging tegen een introductie van AIV en waarschijnlijk de enige verdediging zolang vaccinatie van pluimveekoppels, die het risico lopen om besmet te raken, niet wordt uitgevoerd. Bioveiligheid bestaat uit twee elementen: 'bio-containment' en 'bioexclusion'. Bio-containment betekent het voorkomen van verspreiding van infectieuze agentia vanuit geïnfecteerde pluimveebedrijven. Bio-exclusion verwijst naar de maatregelen om infectieuze agentia buiten de stal te houden van niet-geïnfecteerde pluimveebedrijven [Koch \& Elbers, 2006]. De productie van specific pathogen free (SPF)-kippen, die voornamelijk worden geproduceerd voor veterinaire vaccinproductie en diagnostiek, tonen aan dat bioveiligheidsmaatregelen zeer effectief kunnen zijn. SPFkippen worden gehuisvest in overdruk stallen met gefilterde inkomende lucht (HEPA-filters) waardoor wordt voorkomen dat de kippen in contact komen met specifieke pathogenen (o.a. AI virus).

\section{Referenties}

Beerens, N., et al., Multiple Reassorted Viruses as Cause of Highly Pathogenic Avian Influenza A(H5N8) Virus Epidemic, the Netherlands, 2016. Emerg. Infect. Dis. 2017; 23(12): 1974-1981.

Beerens, N., et al., Genetic relationship between poultry and wild bird viruses during the highly pathogenic avian influenza H5N6 epidemic in the Netherlands, 2017-2018. Transbound. Emerg. Dis. 2019; 66(3): 1370-1378. 
Bouwstra, R., et al., Full-Genome Sequence of Influenza A(H5N8) Virus in Poultry Linked to Sequences of Strains from Asia, the Netherlands, 2014. Emerg. Infec.t Dis. 2015; 21(5): 872-874.

Busquets, N. et al., Persistence of highly pathogenic avian influenza virus (H7N1) in infected chickens: feather as a suitable sample for diagnosis. J. Gen. Virol. 2010; 91( 9): 2307-2313.

Elbers, A.R.W. and J.L. Gonzales, Quantification of visits of wild fauna to a commercial free-range layer farm in the Netherlands located in an avian influenza hot-spot area assessed by video-camera monitoring. Transbound. Emerg. Dis. 2020; 67(2): 661-677.

Germeraad, E.A. et al., Virus Shedding of Avian Influenza in Poultry: A Systematic Review and MetaAnalysis. Viruses, 2019; 11(9): 812. doi: 10.3390/v11090812.

Jonges, M., et al., Wind-Mediated Spread of Low-Pathogenic Avian Influenza Virus into the Environment during Outbreaks at Commercial Poultry Farms. PLoS One 2015; 10(5): e0125401.

Koch, G., Elbers, A.R.W. Outdoor ranging of poultry: A major risk factor for the introduction and development of High-Pathogenecity Avian Influenza. Neth. J. Agr. Sci. 2006; 54: 179-194.

Pantin-Jackwood, M.J., et al., Pathogenicity and Transmission of H5 and H7 Highly Pathogenic Avian Influenza Viruses in Mallards. J. Virol. 2016; 90(21): 9967-9982.

Racicot, M., et al. Description of 44 biosecurity errors while entering and exiting poultry barns based on video surveillance in Quebec, Canada. Prev. Vet. Med. 2011; 100(3-4): 193-199.

Scoizec, A., et al., Airborne Detection of H5N8 Highly Pathogenic Avian Influenza Virus Genome in Poultry Farms, France. Front. Vet. Sci. 2018; 5: 15. doi: 10.3389/fvets.2018.00015.

Stallknecht, D.E. and J.D. Brown, Tenacity of avian influenza viruses. Rev. Sci. Tech. OIE, 2009; 28(1): 59-67.

Swayne, D.E, Suarez, D.L. Sims, L.D. Influenza, in: Diseases of Poultry. 2020: 210-256.

Torremorell, M., et al., Investigation into the Airborne Dissemination of H5N2 Highly Pathogenic Avian Influenza Virus During the 2015 Spring Outbreaks in the Midwestern United States. Avian Dis. 2016; 60(3): p. 637-43.

Velkers, F.C., Blokhuis, S.J., Veldhuis Kroeze, E.J.B., Burt, S.A. The role of rodents in avian influenza outbreaks in poultry farms: a review. Vet. Quart. 2017; 37: 182-194.

Wanaratana, S., Amonsin, A., Chaisingh, A., Panyim, S., Sasipreeyajan, J., Pakpinyo, S. Experimental eassessment of houseflies as vectors in avian influenza subtype H5N1 transmission in chickens. Avian dis. 2013; 57: 266-272.

Yamamoto, Y., Nakamura, K., Mase, M. Survival of Highly Pathogenic Avian Influenza H5N1 Virus in Tissues Derived from Experimentally Infected Chickens. Appl. Environ. Microbiol. 2017; 83(16): e00604-17.

Ypma, R.J.F. et al., Genetic Data Provide Evidence for Wind-Mediated Transmission of Highly Pathogenic Avian Influenza. J. Infect. Dis. 2012; 207(5): 730-735. 


\section{Prevalentie van HPAIV in levende wilde watervogels tijdens HPAI-epidemieën}

\subsection{Inleiding}

De prevalentie van HPAIV in levende wilde watervogels tijdens HPAI-epidemieën is een belangrijke eerste bouwsteen, omdat het helemaal aan het begin staat van de keten van mogelijke omgevingstransmissie: de bron van HPAIV moet aanwezig zijn in de omgeving van pluimveebedrijven (zie figuur 1 in het Voorwoord).

De actieve surveillance om inzicht te krijgen in de mate voorkomen van HPAIV bij levende wilde vogels is wereldwijd gestart na de opkomst en pandemische verspreiding van het Aziatische HPAI subtype H5N1 rond 2005 [Gilbert et al., 2012]. Voor 2005 werd er slechts sporadisch HPAIV gevonden in wilde vogels. Die situatie veranderde toen in April 2005 enkele duizenden wilde vogels geïnfecteerd werden gevonden met HPAI subtype H5N1 bij het Qinghai meer in China [Chen et al., 2005]. Sinds de uitbraak bij het Qinghai meer, zijn het aantal HPAIV-infecties in wilde vogels sterk toegenomen. De verspreiding van het virus vanuit Azië met migrerende wilde vogels naar landen in Europa, Afrika en Noord-Amerika veroorzaakte grote zorg in verband met het risico op introductie van het virus bij commerciële pluimveebedrijven. Actieve surveillance van levende wilde vogels is zeer arbeidsintensief en kostbaar vanwege het vangen en bemonsteren van zeer grote hoeveelheden wilde vogels om daarin naar verwachting slechts enkele besmette vogels te vinden. Verschillende vogelsoorten kunnen worden besmet met HPAIV, maar het zijn voornamelijk migrerende wilde watervogels (van de orde Anseriformes: Eenden, Ganzen, Zwanen) die een rol spelen bij de lange-afstand verspreiding van het virus [Keawcharoen et al., 2008; Verhagen et al., 2015; Lycett et al., 2016]. Deze wilde watervogels kunnen het virus verspreiden naar meer sedimentaire wilde watervogels, b.v. Knobbelzwanen [Promed, 2020].

\subsection{Prevalentie van HPAIV in levende wilde vogels tijdens HPAI- epidemieën}

De literatuur is gescreend m.b.t. publicaties vanaf 2005 die gericht zijn op het meten van de prevalentie van HPAIV in levende wilde vogels tijdens HPAI-epidemieën. Er zijn slechts drie studies gevonden die een schatting hebben gemaakt van de prevalentie van HPAIV in levende wilde vogels tijdens HPAI-epidemieën (Tabel 1). Analyse laat zien dat de prevalentie van HPAIV in levende wilde vogels in de orde ligt van ca. 3 tot 8 per 10.000 bemonsterde wilde watervogels.

Tabel 1 Overzicht van schattingen van de prevalentie van HPAIV in levende wilde watervogels (Anseriformes) tijdens HPAI-epidemieën.

\begin{tabular}{|l|l|l|l|l|l|l|}
\hline Jaar & Land & $\begin{array}{l}\text { Wilde } \\
\text { vogelsoorten }\end{array}$ & $\begin{array}{l}\text { HPAI } \\
\text { virus }\end{array}$ & $\begin{array}{l}\text { Aantal } \\
\text { bemonsterde } \\
\text { wilde vogels }\end{array}$ & $\begin{array}{l}\text { Geschatte } \\
\text { prevalentie }\end{array}$ & Referentie \\
\hline $\begin{array}{l}2003- \\
2009\end{array}$ & Egypte & Anseriformes & H5N1 & 7894 & 0,00025 & $\begin{array}{l}\text { Soliman et al., } \\
2012\end{array}$ \\
\hline 2014 & Nederland & Anseriformes & H5N8 & 4018 & 0,0005 & $\begin{array}{l}\text { Verhagen et al., } \\
2015\end{array}$ \\
\hline 2016 & Nederland & Anseriformes & H5N8 & 1207 & 0,00083 & Poen et al., 2016 \\
\hline
\end{tabular}




\subsection{Conclusie}

Op basis van de gegevens in Tabel 1 is de geschatte gemiddelde prevalentie van HPAIV in levende wilde vogels tijdens een epidemie 5,3 per 10.000 levende wilde watervogels (standaard deviatie: 2,9 per 10.000 levende wilde watervogels).

\section{Referenties}

Chen et al. Avian flu: H5N1 virus outbreak in migratory waterfowl. Nature 2005; 436: 191-192.

Gilbert et al. Highly pathogenic avian influenza among wild birds in Mongolia. PLoS ONE 2012; $7:$ e44097.

Keawcharoen et al. Wild ducks as long-distance vectors of highly pathogenic avian influenza virus (H5N1). Emerg. Infect. Dis. 2008; 14: 600-607.

Lycett et al. Role for migratory wild birds in the global spread of avian influenza H5N8. Science 2016; 354: 213-217.

Poen, et al. Lack of virological and serological evidence for continued circulation of highly pathogenic avian influenza H5N8 virus in wild birds in the Netherlands, 14 November 2014 to 31 January 2016. Euro Surveillance $2016 ; 21(38)$ : 30349.

Promed mail. Avian influenza (70): Netherlands (UT) wild bird, HPAI H5N8, OIE. 26 Oct. 2020. Archive Number: 20201026.7891356

Soliman, A., et al. Surveillance of avian influenza viruses in migratory birds in Egypt, 2003-2009. J. Wildlife Dis. $2012 ; 48(3)$ : 669-675.

Verhagen, J.H., et al. Wild bird surveillance around outbreaks of highly pathogenic avian influenza $A(H 5 N 8)$ virus in the Netherlands, 2014, within the context of global flyways. Euro Surveillance 2015; 20(12): 21069. 


\section{Hoeveel AIV bevat wilde watervogelmest?}

\subsection{Inleiding}

Wilde watervogels van de orde Anseriformes (Eenden, Ganzen, Zwanen) zijn het natuurlijk reservoir van AIV [Stallknecht \& Brown, 2009]. Deze wilde watervogels kunnen een belangrijke rol spelen bij de eerste introductie van het virus in pluimvee, doordat zij het AIV uitscheiden tijdens infectie [Swayne et al., 2020]. Vogels scheiden het virus respiratoir en/of cloacaal uit, dus via secreta uit de neus, mond, conjunctiva en via excreta uit de cloaca. AIV uitgescheiden in wilde watervogelmest, gedeponeerd in de omgeving van een pluimveebedrijf, kan als bron dienen voor introductie van het virus door verplaatsing van deze mest naar pluimvee in de stal. Het doel van dit hoofdstuk is het schatten van de hoeveelheid AIV per gram wilde warervogelmest en de hoeveelheid mest geproduceerd door wilde watervogels.

\subsection{Gehalte aan AIV in wilde watervogelmest}

Er zijn nauwelijks tot geen onderzoeken bekend waarin er gehaltes van AIV per gram mest zijn gemeten in wilde watervogelmest. De meeste studies concentreren zich op het aantonen van specifieke AIVstammen en niet zo zeer op het meten van de concentratie van AIV per gram mest.

$\mathrm{Er}$ is in het verleden slechts één experimentele AIV-infectiestudie uitgevoerd met gedomesticeerde eenden (Cairina moschata) waarin de AIV-gehaltes per gram mest zijn gemeten [Webster et al., 1978]. Na experimentele infectie met $10^{4}$ EID 50 LPAIV subtype H3N6 per gedomesticeerde eend, scheidden de gedomesticeerde eenden gedurende gemiddeld 6 dagen hoge gehaltes aan virus uit: $10^{7}$ tot $10^{8}$ EID 50 per gram mest. Latorre-Margalef et al. [2009] lieten zien in een langdurige surveillance studie van in het wild levende wilde eenden (Anas platyrhynchos) (2002-2007) dat de gemiddelde minimale duur van uitscheiding van LPAIV bij deze wilde eenden 3,1 dag (s.e: 0,1 dag) was; de gemiddelde maximale duur van uitscheiding was 8,3 dagen (s.e.: 0,5 dag).

Er zijn helaas geen kwantitatieve gegevens bekend over AIV-uitscheiding per gram mest in b.v. ganzen of zwanen. Het gemiddelde gewicht van uitwerpselen van ganzen is 3 tot $4 \times$ hoger dan bijvoorbeeld van smienten [Alderisio \& DeLuca, 1999], maar daarmee is niet gezegd dat het gehalte aan uitgescheiden virus per gram mest bij ganzen vergelijkbaar zal zijn met die van b.v. eenden (en dus dat de totale hoeveelheid uitgescheiden virus bij b.v. ganzen 3-4x zo groot zou zijn in vergelijking met wilde eenden).

\subsection{Gemiddeld gewicht van smientenuitwerpselen}

Voor een schatting van het gemiddelde gewicht van smientenuitwerpselen zijn er mestmonsters verzameld in de Nekkeveldpolder bij Nijkerk (Figuur 2), een omgeving waar grote hoeveelheden smienten bij elkaar komen om te foerageren in Januari 2020. Daarnaast zijn er smientenmestmonsters verzameld tijdens de acclimatiseringsfase van een vogelgriepvirus infectieproef met smienten in de high-containment unit van Wageningen Bioveterinary Research in de zomer van 2019. 


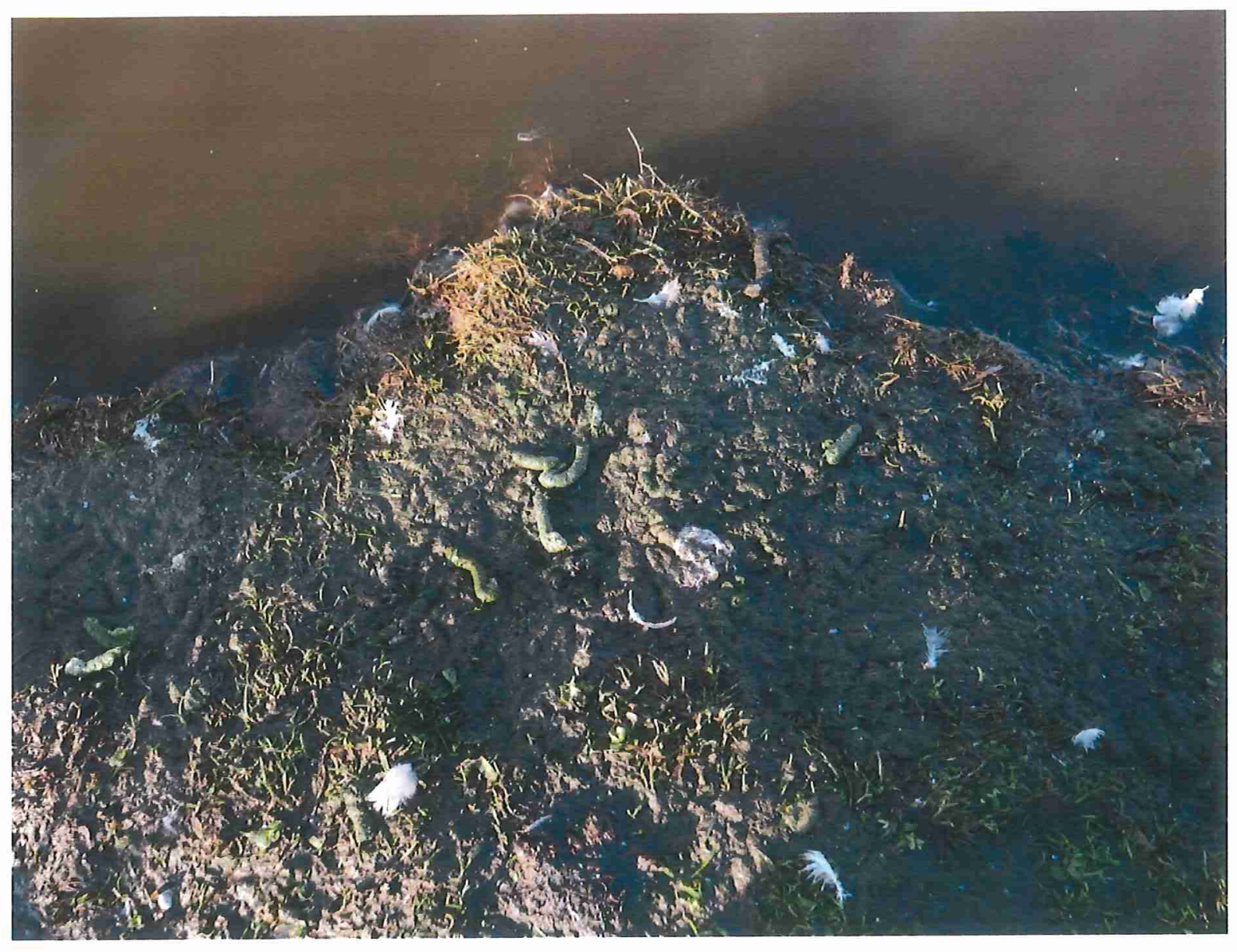

Figuur 2 Smientenuitwerpselen in weilanden aan de rand van sloten in de Nekkeveldpolder bij Nijkerk.

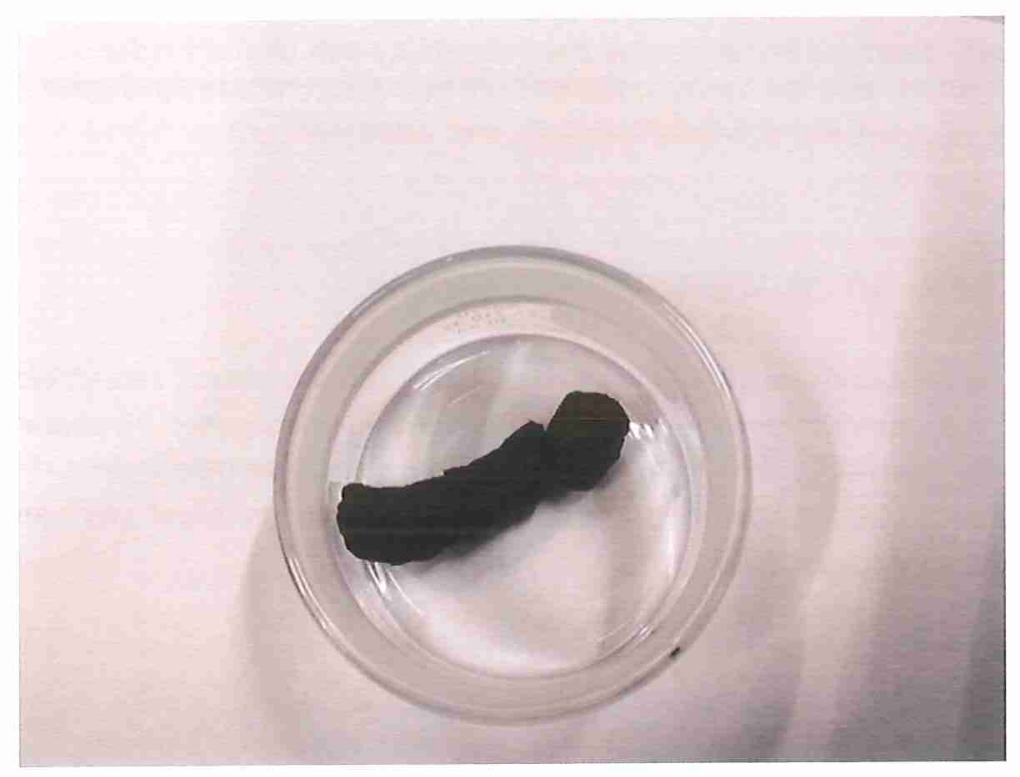

Figuur 3 Een smientenuitwerpsel gereed om gewogen te worden. 
Verzamelde Smientenuitwerpselen zijn gewogen (Figuur 3) en een overzicht van de gemeten gewichten wordt weergegeven in Tabel 1 . Het geschatte gemiddelde gewicht van een smientenuitwerpsel is 2,2 gram (standaard deviatie: 0,8 gram).

Tabel 1 Gewicht van smientenuitwerpselen verzameld in het veld of tijdens een infectieproef met smienten.

\begin{tabular}{|l|l|}
\hline Veld / infectieproef & Gewicht smienten-uitwerpselen (in gram) \\
\hline Veld & 2,895 \\
\hline Veld & 2,921 \\
\hline Veld & 2.406 \\
\hline Veld & 1,800 \\
\hline Infectieproef & 0,869 \\
\hline Infectieproef & 1,654 \\
\hline Infectieproef & 2,538 \\
\hline Infectieproef & 2,051 \\
\hline Infectieproef & 1,811 \\
\hline Infectieproef & 2,130 \\
\hline Infectieproef & 1,575 \\
\hline Infectieproef & 3,307 \\
\hline Infectieproef & 1,232 \\
\hline Infectieproef & 2,109 \\
\hline Infectieproef & 4,154 \\
\hline Gemiddelde & $\mathbf{2 , 2 3}$ \\
\hline s.d. & $\mathbf{0 , 8 4}$ \\
\hline Min. & $\mathbf{0 , 8 6 9}$ \\
\hline Max. & $\mathbf{4 , 1 5 4}$ \\
\hline
\end{tabular}

\subsection{Gemiddeld gewicht van uitwerpselen van andere wilde (water)vogels}

Er zijn nauwelijks tot geen studies gepubliceerd over het gewicht van uitwerpselen van andere wilde (water)vogels. Alderisio \& DeLuca [2005] verzamelden gedurende twee jaar de uitwerpselen van Canadese ganzen (Branta canadensis) en ringsnavelmeeuwen (Larus delawarensis) in Westchester County, N.Y., Verenigde Staten. Op basis van 249 ringsnavelmeeuwkeutels en 236 Canadese ganzenkeutels werd het gemiddelde gewicht van een Canadese ganzenkeutel geschat op 8,3 gram, dat van de ringsnavelmeeuw 0,5 gram. 


\subsection{Frequentie van dagelijks uitscheiden van mest door Smienten}

Om een schatting te maken van de frequentie van mestuitscheiding van Smienten is er gebruik gemaakt van opgenomen videobeelden bij een vogelgriepvirus infectieproef met smienten in de high-containment unit van Wageningen Bioveterinary Research in de zomer van 2019. Dit als een proxi voor de frequentie van mestuitscheiding van smienten in de natuur. In deze proef werden 20 smienten voorafgaande aan de infectieproef gehuisvest in een dierruimte, en van deze smienten werden er videobeelden opgenomen met een videocamerabewakingssysteem (24 uur per dag). In de dierruimte was zwemwater in een bak aanwezig voor de aanwezige smienten. Van de videobeelden werden vier dagen aan opnames geanalyseerd (terugkijken en analyseren van de videobeelden door één persoon), waarbij verschillende observatiemethoden (concentreren van analyseren van videobeelden op een individuele eend gedurende 24 uur, of kleinere groepen smienten (kwadranten) tegelijk en dan uiteindelijk de 4 kwadranten optellen) werden uitgeprobeerd om een goed beeld te krijgen van de frequentie van mestuitscheiding van de smienten.

N.B. Het is zeer waarschijnlijk dat de smienten tijdens het zwemmen in het zwemwater hebben gepoept, dit kon niet met het videocamerabewakingssysteem worden waargenomen. Dat Smienten in het veld onder praktische omstandigheden waarschijnlijk ook, en waarschijnlijk zelfs merendeels, tijdens het zwemmen zullen poepen, is zeer waarschijnlijk. Dat betekent dat de schatting van de frequentie van mestuitscheiding van de smienten grote onzekerheid met zich meebrengt (naast de onzekerheid die het gevolg zijn van het feit dat deze metingen zijn verricht bij gehouden smienten in een dierruimte tijdens de acclimatisatiefase van een infectieproef, en niet gebaseerd zijn op waarnemingen van smienten in hun natuurlijke omgeving).

In Tabel 2 wordt een overzicht gegeven van de gemeten frequentie van mestuitscheiding van de smienten.

Tabel 2 Frequentie van mestuitscheiding van smienten tijdens de acclimatisatiefase in een dierruimte voorafgaande aan een vogelgriepinfectieproef met 20 smienten gedurende vier dagen.

\begin{tabular}{|l|l|l|}
\hline Observatiemethode & Aantal smienten & $\begin{array}{l}\text { Frequentie van mestuitscheiding per } \\
\text { smient per dag }\end{array}$ \\
\hline Individueel & 1 & 1,82 \\
\hline Kwadrantmethode & 20 & 1,35 \\
\hline Kwadrantmethode & 20 & 0,77 \\
\hline Kwadrantmethode & 20 & 0,74 \\
\hline
\end{tabular}

Dat Smienten op weideland, met name langs slootranden, mest uitscheiden is evident, dat is zichtbaar vanuit de waarnemingen opgetekend in Hoofdstuk 6. Maar het is waarschijnlijk dat een aanzienlijk aandeel (waarschijnlijk meer dan 50\%) van de mestuitscheiding van Smienten in zwemwater terecht komt.

\subsection{Frequentie van dagelijks uitscheiden van mest door andere wilde watervogels}

$\mathrm{Er}$ is weinig informatie beschikbaar over mestuitscheidingsfrequentie van andere wilde watervogels. Op internet wordt op een platform aangegeven [https://smallpetsite.com], dat volwassen (wilde) eenden gemiddeld elke 15 tot 30 minuten mest kunnen uitscheiden, dus dat zou 50 tot 100 keer per 24 uur kunnen zijn. Daarbij moet echter worden opgemerkt dat a) waarschijnlijk ca. $50 \%$ van de mestuitscheidingen zullen plaatsvinden op zwemwater, en dus niet op weiland; b) er een aantal uren per dag wordt 
gerust/geslapen, en er dan geen mestuitscheiding zal plaats vinden. Alles bij elkaar is een schatting van de gemiddelde mestuitscheidingsfrequentie van wilde eenden onzeker, maar zou ca. 50 keer per 24 uur op het (wei)land kunnen zijn.

Scheiber et al. [2005] voerden een veldexperiment uit met ganzen om hormoonconcentraties te meten in faeces, waarbij de ganzen kunstmatig werden gevoed met bix en granen. Deze kunstmatige vorm van voeding kan effect hebben gehad op de mestuitscheidingsfrequentie. Gemiddeld was de mestuitscheidingsfrequentie 7,15 keer per 3 uur (s.e.: 0.2), dat is dus gemiddeld ca. 60 keer per 24 uur. Ook hier geldt dat een deel van de mestuitscheiding zou kunnen plaatsvinden in zwemwater, en dus niet op het (wei)land en dat een deel van de dag wordt gerust/geslapen waarbij er geen mestuitscheiding plaats vindt. Alles bij elkaar is een schatting van de gemiddelde mestuitscheidingsfrequentie van ganzen onzeker, maar zou ca. 50 keer per 24 uur op het (wei)land kunnen zijn.

\section{Referenties}

Alderisio, K.A., DeLuca, N. Seasonal enumeration of fecal Coliform bacteria from the feces of ring-billed Gulls (Larus delawarensis) and Canada Geese (Branta canadensis). Appl. Environ. Microbiol. 1999; 65(12): 5628-5630.

Beerens, N., Germeraad, E.A., Venema, S., Verheij, E., Pritz-Verschuren, S.B.E., Gonzales, J.L. Comparative pathogenicity and environmental transmission of recent highly pathogenic avian influenza H5 viruses. Emerg. Microbes \& Infections 2021; 10: 97-108. https://doi.org/10.1080/22221751.2020.1868274.

Latorre-Margalef, N., Gunnarsson, G., Munster, V.J., Fouchier, R.A.M., Osterhaus, A.D.M.E., Elmberg, J., Olsen, B., Wallensten, A., Haemig, P.D., Fransson, T., Brudin, L., Waldenstroem, J. Effects of influenza A virus infection on migrating mallard ducks. Proc. Roy. Soc. B. 2009; 276: 1029-1036.

Scheiber, I.B.R., Kralj, S., Kotrschal, K. Sampling effort/frequency necessary to infer individual acute stress responses from fecal analysis in Greyleg Geese (Anser anser). Ann. N. Y. Acad. Sci. 2005; 1046: 154167.

Stallknecht, D.E. and J.D. Brown, Tenacity of avian influenza viruses. Rev. Sci. Tech. OIE, 2009; 28(1): 59-67.

Swayne, D.E, Suarez, D.L. Sims, L.D. Influenza, in: Diseases of Poultry. 2020: 210-256.

Webster, R.G., Yakhno, M., Hinshaw, V.S., Bean, W.J., Murti, K.G. Intestinal influenza: replication and characterization of influenza viruses in ducks. Virology $1978 ; 84: 268-278$.

Pareek, R.C. The essential guide to duck pooping. https://smallpetsite.com/essential-guide-duck-pooping/ 


\title{
5 Hoe lang persisteert AIV in de omgeving?
}

\author{
5.1 Inleiding
}

Door de structuur van het virus zijn AIVs relatief instabiel in de omgeving [Swayne et al., 2020]. Een AIV partikel heeft als buitenste laag een virale envelop. Deze virale envelop helpt het virus om de gastheer binnen te dringen, maar zodra de virale envelop niet meer intact is, is het virus geïnactiveerd [Quinn et al., 2002]. Fysieke factoren zoals hoge omgevingstemperaturen, extreme $\mathrm{pH}$ waarden van water en droogte in de omgeving [Swayne et al., 2020], en UV straling [Shahid et al., 2009] stimuleren de inactivatie van het virus. Daarentegen beschermen de organische materialen waarin het virus door vogels wordt uitgescheiden, zoals neussecreta en mest, het virus tegen in-activatie door de fysieke factoren [Swayne \& Sims, 2020].

Voor een succesvolle transmissie van AIV via de omgeving is het belangrijk dat het virus infectieus blijft in de omgeving, oftewel persistent is, tot het virus wordt opgenomen door een nieuwe gastheer. Hierbij is de kans op een succesvolle transmissie groter wanneer het virus langer persisteert in de omgeving. Om meer kennis te genereren over de transmissie van AIV zijn er veel experimenten uitgevoerd om te onderzoeken hoe lang AIV persisteert in verschillende omgevingen en omstandigheden [Irwin et al., 2011; Dalziel et al., 2016]. Met name in verschillende soorten water (zoet, brak of zout water) is de persistentie van het virus bij verschillende temperaturen onderzocht. Ook de invloed van micro-organismen in oppervlakte water op de persistentie van AIV is onderzocht door een deel van de watermonster te filtreren, waardoor micro-organismen uit het watermonster worden verwijderd. Vervolgens worden deze watermonsters met virus gespiked en kan de persistentie van het AIV worden vergeleken tussen de gefilterde en niet-gefilterde watermonsters [Domanska et al., 2010; Keeler et al., 2013; Zhang et al., 2014]. Daarnaast is de virus persistentie van AIV onderzocht in mest [Nazir et al., 2011], veren en stuitklierolie [Yamamoto et al., 2017] en op verschillende oppervlaktes [Wood et al., 2010].

Het doel van dit hoofdstuk is om de persistentie data in de literatuur van zowel LPAI als HPAI virussen in oppervlakte water, mest, veren, veerolie en oppervlaktes, onder invloed van verschillende omgevingstemperaturen en UV straling, te bundelen. Met deze dataset wordt getracht om de persistentie van AIVs onder Nederlandse omstandigheden in te schatten.

\subsection{Methode}

\subsubsection{Systematische review methode}

Voor deze literatuurstudie is de aanpak van een systematische review gevolgd. Een systematische review gebruikt vooraf gespecificeerde en gestandaardiseerde methodes om relevante studies te identificeren en data van deze studies te extraheren en te analyseren. In deze literatuurstudie zijn de richtlijnen van het 'Preferred Reporting Items for Systematic Revies and Meta-Analyses (PRISMA)' gevolgd [Moher et al., 2009] met aanpassingen waar nodig, omdat de PRISMA richtlijnen met name voor humane studies zijn ontworpen. De PRISMA review methode biedt belangrijke richtlijnen voor kwaliteitsbeoordeling van artikelen, transparantie in het verzamelen van literatuur en het beperken van publicatie bias. Deze literatuurstudie bestaat uit vier onderdelen: (1) verzamelen van literatuur, (2) screenen van literatuur, (3) 
data extractie en (4) data analyse. Voor de start van het verzamelen van literatuur is volgens de PRISMA methode een protocol ontwikkeld om de verschillende variabelen en uitkomsten te definiëren (zie bijlage 1).

\subsubsection{Verzamelen van literatuur}

Op 26 februari 2020 is een zoekopdracht uitgevoerd in de online database Pubmed. De zoektermen zijn reeds voor de zoekopdracht gedefinieerd en zijn breed opgezet om geen artikelen te missen. Bij het opstellen van de zoektermen is ook de Mesh database van Pubmed gebruikt. De zoektermen waren als volgt:

("Influenza A virus"[Mesh]) AND ("birds [Mesh]) AND Survival ("Influenza in Birds"[Mesh]) AND ("Environmental Exposure" [Mesh])

Avian influenza virus AND environmental persistence

Avian influenza virus AND survival AND humidity

Avian influenza virus AND survival AND temperature

Avian influenza virus AND survival AND Ultraviolet

Avian influenza virus AND survival AND stability

Met behulp van de 'Pubmed data collection tool' zijn automatisch dubbele referenties verwijderd. Naast de primaire zoekopdracht in Pubmed, is het aantal verzamelde studies uitgebreid door de referenties van studies, die waren geselecteerd na de eerste screening, te screenen op relevante referenties die nog niet aanwezig waren in de dataset. Daarnaast is er nog een intern rapport van WBVR toegevoegd aan de dataset. Het verzamelen van literatuur is uitgevoerd door 1 persoon.

\subsubsection{Screenen van literatuur}

$\mathrm{Na}$ het verzamelen van de literatuur zijn titels en samenvattingen van alle verzamelde papers gescreend op relevantie. Als gevolg van de lage specificiteit van de zoektermen bij het verzamelen van de literatuur was het doel van de eerste screening om snel niet-relevante papers te verwijderen. Voor de eerste screening werden de volgende inclusie criteria gehanteerd:

- De studie heeft als onderwerp AIV persistentie in omgeving of producten van pluimvee/vogels

- De studie is een experiment

- De studie is geschreven in het Engels of Nederlands

- $\quad$ De studie is gepubliceerd na 1975

Studies die niet voldeden aan de vier inclusie criteria werden niet geselecteerd voor de tweede screening. Wanneer uit de titel en het abstract niet duidelijk was of aan alle inclusie criteria werd voldaan, werden de studies geselecteerd voor de tweede screening. Het doel van de tweede screening was het selecteren van studies met voldoende relevantie en kwaliteit om antwoord te geven op de onderzoeksvraag. Tijdens de tweede screening werd het hele paper bestudeerd. Tijdens de tweede screening werden de volgende inclusie criteria gehanteerd:

- $\quad$ Er is voldaan aan de inclusie criteria van de eerste screening

- De AIV persistentie is bepaald met behulp van virus/ei isolatie, dus geen (rt-)PCR, en mag zijn doorgerekend met een lineair regressiemodel

- De AIV persistentie moet zijn uitgedrukt in aantal dagen of het aantal dagen moet af te leiden zijn uit de resultaten

- De AIV persistentie is bepaald in water, mest, veren, veerolie of op oppervlaktes

- Wanneer de AIV persistentie is bepaald in water, moet de persistentie zijn bepaald in natuurlijk oppervlakte water. 
In de literatuur zijn meerdere studies die de persistentie van AIV hebben onderzocht in gedistilleerd water. Voordeel van onderzoek in gedistilleerd water is dat verschillende componenten zoals zoutgraad en $\mathrm{pH}$ goed te reguleren zijn en dus de verschillende studies goed te vergelijken zijn. Echter, gedestilleerd water is moeilijk te vergelijken met de complexiteit van natuurlijke water habitatten. Daarnaast zijn er verschillen in de overlevingsduur van AIV aangetoond tussen gedistilleerd water en oppervlakte water [Nazir et al., 2010]. Het doel van deze literatuurstudie is om de persistentie van AIV zo waarheidsgetrouw in te schatten. Daarom is er gekozen om geen persistentie data in de dataset op te nemen die zijn bepaald in gedistilleerd water. Studies met enkel data gegenereerd in gedistilleerd water zijn niet geselecteerd. Wanneer de AIV persistentie in zowel gedestilleerd water als in oppervlakte water of andere geselecteerde materialen was bepaald zijn de studies geselecteerd, maar is de data van het gedistilleerde water niet opgenomen in de dataset.

De screening is uitgevoerd door één auteur, maar bij twijfel is een tweede auteur geraadpleegd. Literatuur dat geen primair onderzoek bevatte, zoals (systematische) reviews, zijn verzameld als achtergrond informatie.

\subsubsection{Data extractie}

Wanneer een studie aan alle criteria voldeed is de data geëxtraheerd en toegevoegd aan de database. De volgende data is toegevoegd in de dataset: (1) AIV subtype, (2) AIV pathotype virus (LPAI of HPAI), (3) type water (zout, brak of zoet), (4) gefilterd of ongefilterd water, (5) oorsprong materialen (6) inoculatie dosis van het te onderzoeken materiaal, (7) methode van bepaling persistentie, (8) de omgevingstemperatuur waarbij het onderzoek werd uitgevoerd en (9) de persistentie van AIV (in dagen). De data extractie is uitgevoerd door één auteur.

\subsubsection{Data analyse}

De data voor persistentie van AIV in de omgeving is geanalyseerd. Voor de analyse van water-gerelateerde data zijn er in het programma Graphpad Prism 8 enkelvoudige lineaire regressie modellen geproduceerd om de persistentie van AIV in verschillende typen water ten opzichte van verschillende omgevingstemperaturen te modelleren. Daarnaast zijn deze lineaire regressie modellen ook geproduceerd om de invloed van micro-organisme op de AIV persistentie inzichtelijk te maken. Observaties zoals '>517 dagen' zijn in de analyse meegenomen als 517 dagen.

Voor de AIV persistentie in mest is de hoeveelheid data beperkt en variëren de werkwijzen in inoculatie route en dosis van de studies sterk. De data voor veren, stuitklierolie, oppervlaktes en de invloed van UVlicht is ook beperkt. Een data analyse is dus niet mogelijk en daarom zijn verschillende parameters die zijn verzameld uit de studies in tabellen geplaatst.

\subsection{Resultaten}

\subsubsection{Verzamelen en screenen van literatuur}

Tabel 3 geeft een overzicht van het verzamelen van de literatuur. Met de opgestelde zoektermen zijn in Pubmed 449 identieke studies verzameld. Tijdens de eerste literatuur screening op titel en samenvatting bleken slechts 69 studies relevant. Tijdens de tweede screening is dit aantal teruggebracht naar 18 publicaties. Dankzij het doornemen van de referentie lijsten van de studies die tijdens de tweede screening waren geïncludeerd, zijn 4 studies extra toegevoegd aan de selectie. In totaal is de data van 22 studies opgenomen in de database. Voor een overzicht van de geselecteerde studies, zie bijlage 2 . 
Tabel 3 Verzamelen en screenen van literatuur.

\begin{tabular}{ll}
\hline Sian & Atrinal stindes \\
\hline Literatuur verzameling & 496 Pubmed +1 intern \\
\hline Deduplicatie & 449 \\
\hline Eerste literatuur screening & 69 \\
\hline Tweede literatuur screening & 18 \\
\hline Toegevoegd d.m.v. referentielijst & 4 \\
van geselecteerde artikelen & \\
\hline In dataset & $\mathbf{2 2}$ \\
\hline
\end{tabular}

\subsubsection{Data analyse}

\subsubsection{De persistentie van AIV in oppervlalkte water}

De persistentie van AIV is veruit het meest onderzocht in water. In totaal zijn er in de dataset 228 observaties geëxtraheerd uit de literatuur. Tabel 4 geeft een overzicht van de geëxtraheerde data voor het bepalen van de persistentie in water. De persistentie van LPAIV is vaker onderzocht dan de persistentie van HPAIV. Daarnaast is de persistentie van LPAIV voor meerdere subtypes onderzocht, in tegenstelling tot HPAIV, waar alleen de persistentie van H5N1 virussen is onderzocht. Van de variabele 'watertype' is zoet water het meest onderzocht gevolgd door respectievelijk brak en zout water. Het filteren van water is gebruikt om de invloed van micro-organismen op de AIV persistentie te bepalen. Het filter vangt microorganismen weg uit de watermonsters, waardoor de AIV persistentie gemeten kan worden in de af- én aanwezigheid van micro-organismen.

Tabel 4 Een overzicht van de geëxtraheerde data uit de studies voor het bepalen van de persistentie in water.

\begin{tabular}{|c|c|c|c|}
\hline & & IPRAT & LPAI \\
\hline \multirow[t]{12}{*}{ Subtype virus } & H3N6 & 0 & 1 \\
\hline & H3N7 & 0 & 1 \\
\hline & H3N8 & 0 & 20 \\
\hline & H4N6 & 0 & 18 \\
\hline & H5N1 & 36 & 43 \\
\hline & H5N7 & 0 & 27 \\
\hline & $\mathrm{H} 6 \mathrm{~N} 2$ & 0 & 10 \\
\hline & H6N8 & 0 & 10 \\
\hline & H7N1 & 0 & 26 \\
\hline & $\mathrm{H} 8 \mathrm{~N} 4$ & 0 & 2 \\
\hline & H9N2 & 0 & 24 \\
\hline & H11N6 & 0 & 10 \\
\hline \multirow[t]{3}{*}{ Water type } & Zoet & 14 & 123 \\
\hline & Brak & 20 & 29 \\
\hline & Zout & 2 & 40 \\
\hline \multirow[t]{2}{*}{ Gefilterd water } & $\mathrm{Ja}$ & 24 & 75 \\
\hline & Nee & 12 & 117 \\
\hline
\end{tabular}


Middels een lineaire regressielijn is per type water (zoet, brak of zout) de persistentie van LPAIV en HPAIV bij oplopende omgevingstemperaturen bepaalt (Figuur 3a). Uit de dalende regressielijnen kan worden geconcludeerd dat AIV in alle watertypes minder lang persisteert bij hogere omgevingstemperaturen dan bij lagere omgevingstemperaturen. In alle watertypes persisteert LPAIV langer dan HPAIV. LPAIV persisteert het langst in zoet water: gemiddeld \pm 110 dagen bij $-10^{\circ} \mathrm{C}, 85$ dagen bij $0^{\circ} \mathrm{C}$, 60 dagen bij $10^{\circ} \mathrm{C}$ en 40 dagen bij $20^{\circ} \mathrm{C}$. De maximale gemeten persistentie van LPAIV in zoet water is 517 dagen. In brak water persisteren LPAIV gemiddeld \pm 43 dagen bij $10^{\circ} \mathrm{C}$ en bijna 30 dagen bij $20^{\circ} \mathrm{C}$. HPAIV persisteren gemiddeld korter in zoet water dan de LPAIV in brak en zout water. Opvallend is dat de persistentie van HPAIV in zoet water korter is dan in brak water. HPAIV persisteren bij $5^{\circ} \mathrm{C}$ gemiddeld een aantal dagen minder lang in brak water dan LPAIV doen in ditzelfde watertype. Echter, HPAIV persisteren langer bij hogere omgevingstemperaturen dan LPAIV in brak water.

a)

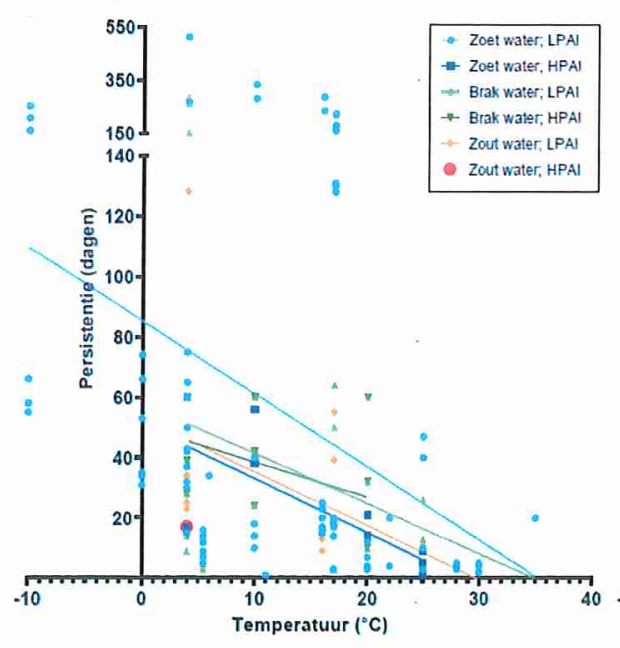

b)

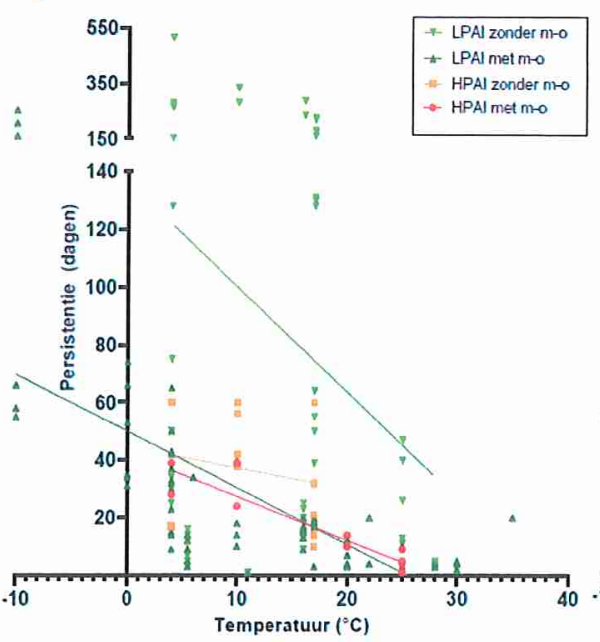

c)

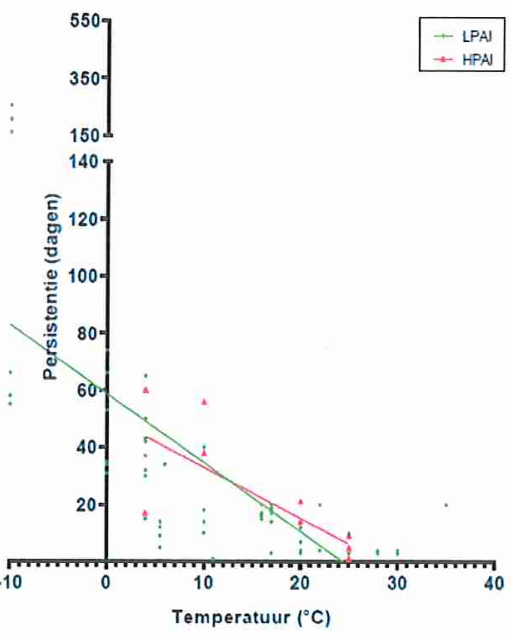

Figuur 3 De persistentie in dagen van a) LPAI en HPAI virussen in verschillende typen water, b) LPAI en HPAI virussen in water met- en zonder micro-organismen $(m-0)$, c) LPAI en HPAI virussen in zoet water met micro-organismen, bij verschillende omgevingstemperaturen $\left({ }^{\circ} \mathrm{C}\right)$.

De regressielijnen in figuur $3 \mathrm{~b}$ tonen aan dat de aanwezigheid van micro-organismen de persistentie van zowel HPAI als LPAI virussen verkorten. In watermonsters zonder micro-organismen is de persistentie van LPAI virussen bij $10^{\circ} \mathrm{C} \pm 100$ dagen, in tegenstelling tot water met micro-organismen waar LPAI virussen gemiddeld slechts \pm 30 dagen persisteren. HPAI virussen zijn minder persistent dan de LPAI virussen: HPAI virussen zonder micro-organismen persisteren \pm 40 dagen bij $10^{\circ} \mathrm{C}$, terwijl HPAI virussen met microorganismen in het water \pm 25 dagen persisteren.

Figuur 3c geeft de AI virus persistentie weer in zoet water met micro-organismen. Dit is de meest relevante situatie voor Nederlandse pluimveebedrijven. LPAIV persisteren gemiddeld 60 dagen bij $0^{\circ} \mathrm{C}, 50$ dagen bij $4^{\circ} \mathrm{C}$ en 30 dagen bij $12^{\circ} \mathrm{C}$. HPAIV persisteren gemiddeld 45 dagen bij $4{ }^{\circ} \mathrm{C}$ en 30 dagen bij $12^{\circ} \mathrm{C}$.

\subsubsection{Overleving van AIV in mest}

De geëxtraheerde data over de AIV persistentie in mest is weergeven in tabel 5 . Ook in mest is AIV meer persistent bij lagere omgevingstemperaturen. Bij $0^{\circ} \mathrm{C}$ kan AIV tot wel 451 dagen persisteren [Nazir et al., 2011], terwijl het virus nog geen dag persisteert bij $42^{\circ} \mathrm{C}$ [Kurmi et al., 2013]. Bij $4^{\circ} \mathrm{C}$ persisteert AIV minimaal drie weken. De resultaten van de verschillende studies variëren, mogelijk is de persistentie afhankelijk van de inoculatie route, waarbij een langere persistentie wordt gemeten na een inoculatie via kiemdragers, een soort filter waar de AIV op zijn geplaatst. Op basis van deze literatuur kan er geen verschil in persistentie tussen HPAIV en LPAIV worden aangetoond. 
Tabel 5 De persistentie van AIV in mest (in dagen).

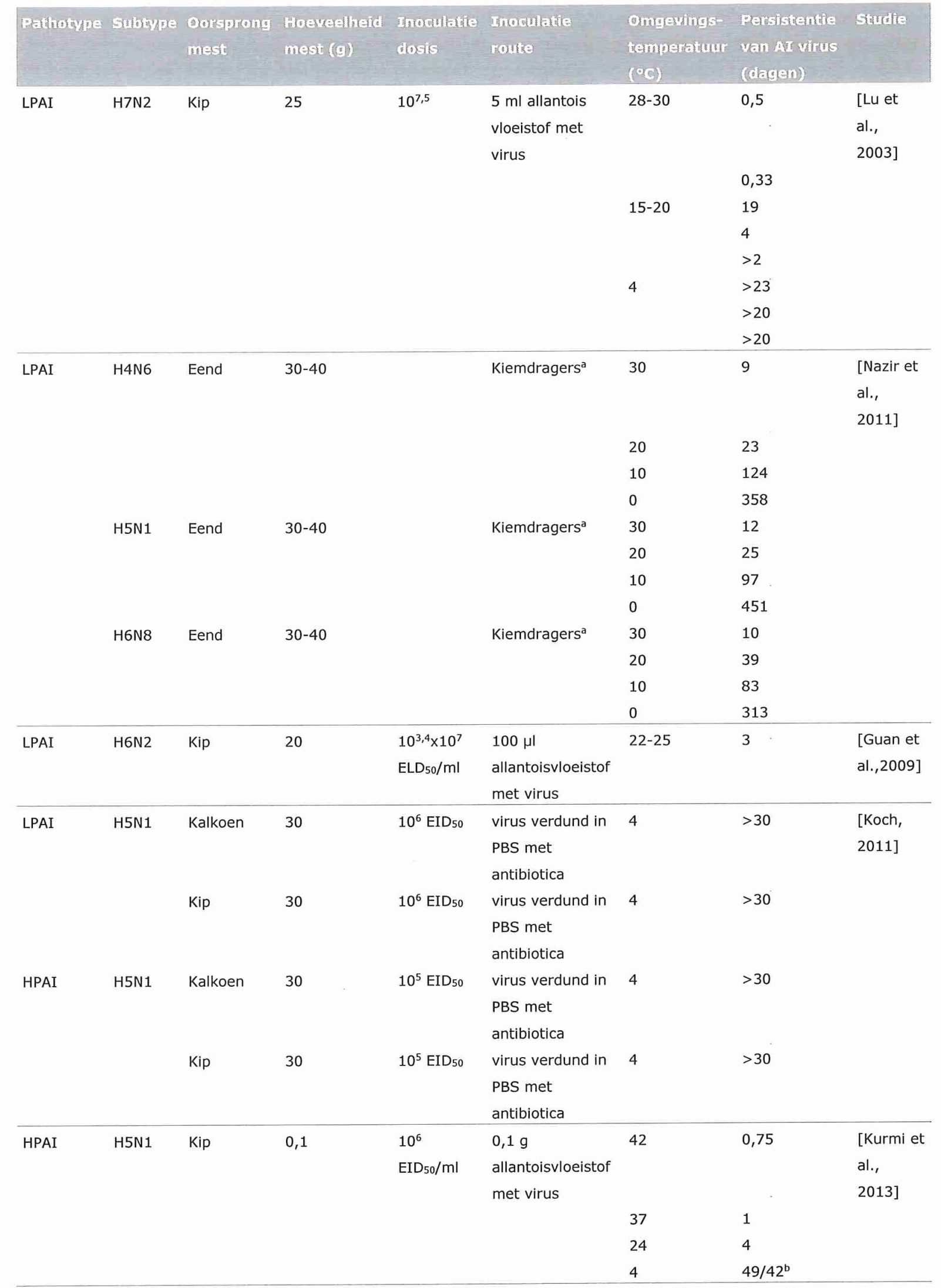

akiemdragers: een soort filter waar de virussen op zijn geplaatst. Van deze filters zijn er 3 per mestmonster aangebracht. 
' In deze studie is de persistentie van AIV zowel in het natte als het droge deel van de mest bepaalt. De persistentie tussen beide type mest was bij de verschillende temperaturen gelijk m.u.v. de persistentie bij $4^{\circ} \mathrm{C}$ : in de droge mest 49 dagen en in de natte mest 42 dagen.

Er is slechts één studie [Zarkov \& Urumova, 2013] die tegelijk de invloed van relatieve vochtigheid en temperatuur heeft onderzocht en daarnaast ook de vochtigheid van de mest heeft meegenomen in de tijd (dus invloed van uitdrogen van de mest) op persistentie van LPAIV subtype H6N2 in mest van wilde eenden (Anas plathyrynchos) die experimenteel besmet waren met het LPAI H6N2 virus. Bij een constante omgeving-temperatuur van $15^{\circ} \mathrm{C}$ en relatieve vochtigheid van de lucht van $60 \%$, verdween de initiële virus titer van $10^{4.0}$ EID50/100 $\mu \mathrm{L}$ naar 0 binnen twee dagen in de eendenmest; De vochtigheid van de eendenmest nam in dit traject af tot $20 \%$ van de oorspronkelijke vochtigheid, dus er trad een sterke verdroging op.

Samenvattend wordt duidelijk dat bij lage temperatuur AIV in mest langdurig kan overleven; bij dergelijke temperaturen blijft de vochtigheid van de mest ook nagenoeg gelijk omdat het niet kan verdrogen. Zo gauw de mest echter sterk verdroogd bij hoge temperaturen, verliest het virus zijn levensvatbaarheid, die parallel gaat met het verliezen aan vochtigheid.

\subsubsection{Overleving van AIV in veren en veerolie}

HPAI virussen kunnen ook worden gedetecteerd in veren en stuitklierolie. Verschillende studies hebben de persistentie van HPAIV in veren bepaalt. Tabel 6 geeft een overzicht van de persistentie van HPAIV die is verkregen middels vergelijkbare dierexperimenten. In deze experimenten zijn Wilde Eenden, kippen en/of kalkoenen geïnoculeerd met een HPAIV. Tijdens sectie zijn veren verzameld en middels virusisolatie (VI) in eieren of celtitratie is de persistentie van AIV onder diverse temperaturen vastgesteld. Ook hier geldt dat AIV persistenter is bij lagere omgevingstemperaturen. Drie studies hebben de persistentie van H5N1 virussen bij 4 en $20^{\circ} \mathrm{C}$ bepaalt en het virus persisteert bij $4^{\circ} \mathrm{C}$ minimaal 34 dagen. $\mathrm{Bij} 20^{\circ} \mathrm{C}$ is dit significant lager en persisteert het virus tussen de $<10$ en 30 dagen. De persistentie van een H7N1 virus in veren is bij hogere temperaturen gemeten en is dus niet te vergelijken met de H5N1 persistentie. In een ander dierexperiment zijn ook veren verzameld van kippen geïnfecteerd met HPAIV H7N7. In de RT-PCR waren de veren op 2 dpi en 3 dpi positief, maar er is geen infectieus virus aangetoond in virusisolatie [Koch, 2011].

Tabel 6 De persistentie van AIV in veren welke onderzocht is middels het verzamelen van veren bij sectie in dierexperimenten.

\begin{tabular}{|c|c|c|c|c|c|}
\hline Subtype & Oorsprong veren & Methode & $\begin{array}{l}\text { Omgevings- } \\
\text { temperatur ( }\left({ }^{\circ} \theta\right)\end{array}$ & $\begin{array}{l}\text { Persistentie vam AI } \\
\text { virus (cagen) }\end{array}$ & Referentie \\
\hline \multirow[t]{2}{*}{ H5N1 } & Wilde eend & VI in eieren & 4 & 160 & $\begin{array}{l}\text { [Yamamoto et al., } \\
\text { 2010] }\end{array}$ \\
\hline & & VI in eieren & 20 & 15 & \\
\hline \multirow[t]{2}{*}{ H5N1 } & Kip & VI in eieren & 4 & 240 & $\begin{array}{l}\text { [Yamamoto et al., } \\
\text { 2017] }\end{array}$ \\
\hline & Kip & VI in eieren & 20 & 30 & \\
\hline \multirow[t]{2}{*}{ H5N1 } & Kip/kalkoen & VI in eieren & 4 & $>34$ & [Koch, 2011] \\
\hline & Kip/kalkoen & VI in eieren & 20 & $<10$ & \\
\hline \multirow[t]{2}{*}{ H7N1 } & Kip & Celtitratie & $22-23$ & 5 & $\begin{array}{l}\text { [Busquets et al., } \\
\text { 2010] }\end{array}$ \\
\hline & & & $30-31$ & 2 & \\
\hline
\end{tabular}


De persistentie van AIV is ook met behulp van andere methoden onderzocht. Karunakaran et al. [2019] hebben verschillende type veren gespiked met een lage en een hoge virusconcentraties ( $10^{4}$ EID50 en $10^{6}$ EID50) van een HPAIV H5N1. De persistentie van het AI virus is getest bij $37^{\circ} \mathrm{C}, 25^{\circ} \mathrm{C}$ en $10^{\circ} \mathrm{C}$. Een maximale AI virus persistentie is aangetoond in de veren van volwassen eenden gespiked met de hoge dosis: bij $10^{\circ} \mathrm{C}$ persisteerde het virus gemiddeld 73 dagen en bij $25^{\circ} \mathrm{C}$ gemiddeld 45 dagen. Bij veren waar de stuitklierolie was verwijderd bedroeg de persistentie nog 48 dagen bij $10^{\circ} \mathrm{C}$ en 25 dagen bij $25^{\circ} \mathrm{C}$, wat illustreert dat stuitklierolie zorgt voor een langere persistentie van het virus. In kuikens van 1 uur oud was het virus minder persistent: 41 dagen bij $10^{\circ} \mathrm{C}$. Het HPAIV was bij de lagere virusconcentratie in alle dieren minder persistent. In de studie van Tiwari et al. [2006] is de AIV persistentie op verschillende oppervlakten, waaronder veren, onderzocht. Hiervoor is een veer gespiked met virus. Het H13N7 virus was nog infectieus op 6 dagen, maar niet meer op het volgende monstermoment van 9 dagen. In de studie van Delogu et al. [2012] is het veerkleed van zeven Wilde Eenden (Anas plathyrhynchos) ingesmeerd met stuitklierolie dat was gespiked met een LPAIV H1ON7. Hierbij is getracht om een natuurlijke situatie na te bootsen: de grootte van het oppervlakte dat besmeerd is met olie is gebaseerd op de hoeveelheid olie in wilde vogels. Op meerdere dagen zijn er swabs van het veerkleed genomen. Op vier aansluitende monstermomenten, dag 10, 18, 26 en 32, is er in alle acht eenden RNA van AI virus gedetecteerd met behulp van de RT- PCR. Het volgende monstermoment, dag 45, waren alle swabs negatief. Van de swabs die positief waren in de RT-PCR is geprobeerd het virus te isoleren. Op dag 18 was uit 1 van de 8 swabs, op dag 26 waren uit 3 van de 8 swabs (incl. controle eend) en op dag 32 was het uit 1 van de 8 swabs mogelijk om infectieus virus te isoleren. Kortom, deze studie toont aan dat AIV 32 dagen kan persisteren op het verenkleed.

een roofvogel, het zich niet kan 'permitteren' om tijdelijk niet te kunnen vliegen. Die hebben dan ook een andere, meer geleidelijke, ruistrategie.

De vraag blijft hoe groot het risico is die veren van HPAIV-besmette wilde vogels vormen voor AIVtransmissie naar pluimvee. "Het op natuurlijke wijze vrij komen van grotere hoeveelheden veren (rui) is een vrij complex gebeuren, met verschillen per soort, per leeftijdsgroep en per veerpartij. Sommige soorten hebben als strategie om in korte tijd hun slagpennen te ruien, waardoor ze zelfs tijdelijk niet kunnen vliegen. Die strategie is gebruikelijk voor meerdere soorten Eendachtigen. Deze strategie is alleen mogelijk voor soorten die in die periode niet erg mobiel hoeven te zijn om aan voedsel te komen. Zwemmend en lopend, op voedselrijke plekken met weinig verstoring, is dit voor sommige soorten 'te doen'. Maar je kunt je voorstellen dat bijv. eer geleidelijke, ruistrategie. Veel soorten vogels gebruiken de ruiperiode direct na het broedseizoen ('de zomer') om een flink deel van hun rui te volbrengen. Vaak zijn dit de veerpartijen die een belangrijke functie vervullen bij het vliegen ('slagpennen'). Sommige soorten vertonen zelfs duidelijke rui-trek, naar specifieke plekken waar ze in grote groepen de rui doormaken. Voorbeelden zijn Grote Canadese Gans (Branta canadensis) (eind mei/juni) en Bergeend (Tadorna tadorna) (juni/juli)" [pers. comm. Roy Slaterus]. Dit betekent dat de natuurlijke ruiperiode buiten de vogelgriep risicoperiode valt. In de vogelgriep risicoperiode kunnen echter wel veren vrijkomen van karkassen van dode, HPAIV-besmette wilde (water)vogels. De mate waarin dit gebeurt is echter een onbekende. Een aanzienlijk deel van de karkassen van dode wilde (water)vogels worden in het water gevonden tijdens de vogelgriep risicoperiode, en met een wisselende periodelengte uit het water gehaald door verschillende instanties. Sommige van deze karkassen spoelen aan land aan, of dode vogels worden gevonden in weilanden. Aaseters (b.v. meeuwen, roofvogels) zullen tijdens het eten van karkassen van dode, HPAIVbesmette wilde (water)vogels ervoor kunnen zorgen dat er veren los komen van het karkas. Deze veren kunnen dan met de wind vervoerd worden en ook in de omgeving van pluimveestallen en zelfs mogelijk door de luchtinlaat van pluimveestallen in de stal terecht komen en daar mogelijk worden opgegeten door aanwezig pluimvee. De kans waarmee dit gebeurt is onbekend, basale gegevens ontbreken om hier ook een zinnig inschatting van de maken. Daarbij valt te denken aan gebrek aan gegevens over: hoe veel wilde vogels gaan er dood aan HPAIV; welke deel daarvan wordt gevonden en hoe lang duurt het voordat ze worden opgeruimd; hoe vaak wordt er gegeten van karkassen door aaseters; komen bij het eten van karkassen door aaseters daar dan veren bij vrij; hoe veel veren komen er dan vrij; over welke afstand worden veren door wind verspreid; welke fractie van losgelaten veren komt bij stal terecht; hoe vaak komt het voor dat veren via luchtinlaat in stal komen, hoe vaak eten kippen dan veren op, en welke fractie van de binnengekomen veren, etc.. 
Maar het is duidelijk dat dit theoretisch kan gebeuren. Evident dat het gevaar wat groter zal zijn als de dode wilde vogels dichter bij pluimveebedrijven worden gevonden dan op grotere afstand. Maar voor opruimdiensten is het denk ik niet bekend op wat voor afstand pluimveebedrijven zitten t.o.v. de vindplaats van de dode wilde vogels; dan zou er beter van een voorzorg principe kunnen worden uitgegaan door ervoor te zorgen dat er actief naar dode wilde vogels in de vogelgriep risicoperiode wordt gezocht en dat karkassen na vondst zo spoedig mogelijk worden opgeruimd. Het is evident dat grotere groepen dode wilde vogels (en daar speelt gewicht dan ook een additionele rol: vogels met een groter gewicht, dus grotere vogels als zwanen en ganzen brengen meer 'gewicht' in de schaal als het gaat over het gevaar dan kleinere zangvogels) een groter gevaar zijn dan kleinere groepen dode wilde vogels omdat er dan meer aasmateriaal is, en dus meer mogelijkheid is voor aaseters om aan de karkassen te gaan eten, waarbij veren zouden kunnen vrijkomen. Het is daarom belangrijk dat karkassen van wilde (water)vogels zo spoedig mogelijk na het sterven van de vogels worden verwijderd uit de omgeving en vernietigd. Het tegenhouden van wilde vogelveren bij de luchtinlaat van pluimveestallen kan met gaas (daarmee kunnen ook b.v. wilde vogels zoals spreeuwen en mussen worden tegengehouden), maar dit gaas hoeft niet zo fijnmazig te zijn als windbreekgaas.

\subsubsection{Overleving van AIV op verschillende materialen}

De verzamelde gegevens over de persistentie van AIV op verschillende ondergronden zijn weergegeven in tabel 7. Op de meeste ondergronden persisteert het virus minder dan 6 dagen bij kamertemperatuur. Bij $4^{\circ} \mathrm{C}$ persisteert HPAIV H5N1 13 dagen op metaal en glas. In sloot/beeksediment persisteert het virus langer ( $>27$ dagen bij $30^{\circ} \mathrm{C}$ ). Echter, Horm et al. [2012] kon geen infectieus AIV isoleren uit grond- en moddermonsters, ondanks dat de RT-PCR, AIV RNA aantoonde t/m 14 dagen na monstername. Dit impliceert dat het virus slechts een beperkte tijdslengte infectieus blijft in grondmonsters. 
Tabel 7 Persistentie van AIV op verschillende ondergronden.

\begin{tabular}{|c|c|c|c|c|c|c|c|c|}
\hline Pathotype & Stifisype & Oppremblakte & 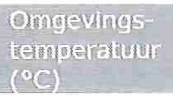 & $\begin{array}{l}\text { Relatileye } \\
\text { lucht- } \\
\text { Yashingheid }\end{array}$ & $\begin{array}{l}\text { Inogenlatile } \\
\text { grosis }\end{array}$ & Mathode & $\begin{array}{l}\text { Persistentile } \\
\text { van Al virus } \\
\text { (dergen) }\end{array}$ & Retefentile \\
\hline \multirow[t]{11}{*}{ LPAI } & \multirow[t]{11}{*}{ H13N7 } & Staal & KT & & $\begin{array}{l}6,3 \times 10^{4} \\
\text { TCID } 50\end{array}$ & Celtitratie & $3(<6)$ & \multirow[t]{11}{*}{$\begin{array}{l}\text { [Tiwari et } \\
\text { al., 2006] }\end{array}$} \\
\hline & & Latex & $\mathrm{KT}$ & & & & $6(<9)$ & \\
\hline & & Tegels & $\mathrm{KT}$ & & & & $3(<6)$ & \\
\hline & & Hout & $\mathrm{KT}$ & & & & $3(<6)$ & \\
\hline & & $\begin{array}{l}\text { Rubberen } \\
\text { laarzen }\end{array}$ & $\mathrm{KT}$ & & & & $3(<6)$ & \\
\hline & & Banden & $\mathrm{KT}$ & & & & $3(<6)$ & \\
\hline & & Eiertree & $\mathrm{KT}$ & & & & $3(<6)$ & \\
\hline & & Eischaal & $\mathrm{KT}$ & & & & $3(<6)$ & \\
\hline & & Stof (katoen) & $\mathrm{KT}$ & & & & $3(<6)$ & \\
\hline & & $\begin{array}{l}\text { Stof } \\
\text { (polyester) }\end{array}$ & $\mathrm{KT}$ & & & & $3(<6)$ & \\
\hline & & Plastic & $\mathrm{KT}$ & & & & $3(<6)$ & \\
\hline \multirow[t]{12}{*}{ HPAI } & \multirow[t]{12}{*}{ H5N1 } & \multirow[t]{4}{*}{ Metaal } & $\mathrm{KT}$ & $\pm 30 \%$ & $\begin{array}{l}5 \times 10^{6} \mathrm{t} / \mathrm{m} \\
5 \times 10^{7} \\
\text { TCID } 50\end{array}$ & Celtitratie & $<1$ & \multirow[t]{12}{*}{$\begin{array}{l}\text { [Wood et } \\
\text { al., 2010] }\end{array}$} \\
\hline & & & $\mathrm{KT}$ & $\pm 90 \%$ & & & $<1$ & \\
\hline & & & 4 & $15-46 \%$ & & & 13 & \\
\hline & & & 4 & $79-97 \%$ & & & 4 & \\
\hline & & \multirow[t]{4}{*}{ Glas } & $\mathrm{KT}$ & $\pm 30 \%$ & & & $<1$ & \\
\hline & & & $\mathrm{KT}$ & $\pm 90 \%$ & & & $<1$ & \\
\hline & & & 4 & $15-46 \%$ & & & 13 & \\
\hline & & & 4 & $79-97 \%$ & & & 9 & \\
\hline & & \multirow[t]{4}{*}{$\begin{array}{l}\text { Modder/ } \\
\text { Grond }\end{array}$} & KT & $\pm 30 \%$ & & & 1 & \\
\hline & & & $\mathrm{KT}$ & $\pm 90 \%$ & & & 1 & \\
\hline & & & 4 & $15-46 \%$ & & & 13. & \\
\hline & & & 4 & $79-97 \%$ & & & 9 & \\
\hline \multirow[t]{4}{*}{ LPAI } & \multirow[t]{4}{*}{ H4N6 } & \multirow[t]{4}{*}{$\begin{array}{l}\text { Sloot/Beek- } \\
\text { Sediment }\end{array}$} & 30 & & $\begin{array}{l}\text { kiemdrager } \\
10^{3} \\
\text { TCID50/ml }\end{array}$ & Celtitratie & 64 & \multirow[t]{12}{*}{$\begin{array}{l}\text { [Nazir et } \\
\text { al., 2011] }\end{array}$} \\
\hline & & & 20 & & & & 109 & \\
\hline & & & 10 & & & & 259 & \\
\hline & & & 0 & & & & 395 & \\
\hline \multirow[t]{4}{*}{ LPAI } & \multirow[t]{4}{*}{ H5N1 } & \multirow[t]{4}{*}{$\begin{array}{l}\text { Sloot/Beek- } \\
\text { Sediment }\end{array}$} & 30 & & & & 43 & \\
\hline & & & 20 & & & & 76 & \\
\hline & & & 10 & & & & 282 & \\
\hline & & & 0 & & & & 705 & \\
\hline \multirow[t]{4}{*}{ LPAI } & \multirow[t]{4}{*}{ H6N8 } & \multirow[t]{4}{*}{$\begin{array}{l}\text { Sloot/beek- } \\
\text { Sediment }\end{array}$} & 30 & & & & 27 & \\
\hline & & & 20 & & & & 102 & \\
\hline & & & 10 & & & & 322 & \\
\hline & & & 0 & & & & 2363 & \\
\hline
\end{tabular}

KT: Kamertemperatuur 


\subsection{Conclusie}

- De persistentie van zowel HPAIV als LPAIV neemt af bij hogere omgevingstemperaturen in alle onderzochte materialen, zoals water, mest, veren, veerolie, verschillende oppervlaktes en sediment.

- De persistentie van AIV in water wordt beïnvloed door het type water (zoet, brak en zout) en de aan/afwezigheid van micro-organismen. In alle watertypes persisteert LPAIV langer dan HPAIV. LPAIV persisteert het langst in zoet water: LPAIV persisteren in zoet water met micro-organismen gemiddeld 60 dagen bij $0^{\circ} \mathrm{C}, 50$ dagen bij $4^{\circ} \mathrm{C}$ en 30 dagen bij $12^{\circ} \mathrm{C}$. HPAIV persisteren gemiddeld 45 dagen bij $4^{\circ} \mathrm{C}$ en 30 dagen bij $12^{\circ} \mathrm{C}$ in zoet water met micro-organismen.

- In pluimvee mest persisteert AIV minimaal drie weken bij $4^{\circ} \mathrm{C}$.

- In veren is het AIV persistenter dan in mest: het virus persisteert minimaal 34 dagen bij $4^{\circ} \mathrm{C}$. Het is belangrijk dat karkassen van dode, met HPAIV-besmette wilde (water)vogels zo spoedig mogelijk na sterfte uit de natuurlijke omgeving worden opgeruimd omdat zij de bron zouden kunnen zijn van losse veren; deze zouden vrij kunnen komen als aaseters aan karkassen eten en mogelijk met de wind naar de omgeving en mogelijk luchtinlaat van pluimveestallen kunnen worden vervoerd. Basale gegevens over de mate waarin dit zou kunnen gebeuren ontbreken, waardoor er geen onderbouwde risicoanalyse kan worden uitgevoerd, het blijft bij theoretische mogelijkheid.

- Op de meeste ondergronden persisteert het virus minder dan 6 dagen bij kamertemperatuur, maar op geaffineerd metaal en glas persisteert HPAIV H5N1 13 dagen bij $4^{\circ} \mathrm{C}$.

- In sloot/beeksediment is het virus nog persistenter dan op andere materialen, d.w.z. minimaal 76 dagen bij $20^{\circ} \mathrm{C}$, en nog langer bij lagere temperaturen.

- Een hoge relatieve luchtvochtigheid verkort de persistentie van AIV op diverse materialen bij lage temperaturen $\left(4^{\circ} \mathrm{C}\right)$, maar er is geen afname van persistentie aangetoond bij $20^{\circ} \mathrm{C}$.

\subsection{Discussie}

De persistentie van AIV die zijn bepaald in experimenten kunnen niet één op één vertaald worden naar de AIV persistentie in natuurlijke situaties. Ten eerste is in experimenten de invloed van één parameter, soms twee parameters, op de persistentie van AIV onderzocht, bijvoorbeeld de temperatuur of de invloed van micro-organismen. Echter, in natuurlijke situaties zijn er meerdere parameters die gelijktijdig invloed uitoefenen op de persistentie van AIV, bijvoorbeeld temperatuur, relatieve luchtvochtigheid én blootstelling aan UV-licht. Ten tweede hebben AIV in een natuurlijke omgeving te maken met variërende omgevingstemperaturen en relatieve luchtvochtigheden. Temperatuurverschillen spelen een grote rol in de persistentie van AIV in de omgeving: een vries-dooi stap van $-10^{\circ} \mathrm{C}$ naar $4^{\circ} \mathrm{C}$ van water zorgt voor een 2-3 log afname van TCID 50 van AIV [Nazir et al., 2010]. Deze significante afname in persistentie van AIV in water is ook bevestigd in gedistilleerd water [Stallknecht et al., 2010; Lebarbenchon et al., 2011]. Ten derde zijn in de natuur complexe biotopen aanwezig. In deze literatuurstudie is gekozen voor natuurlijke watermonsters in plaats van gedistilleerd water, om dit verschil al op te vangen, maar in de natuur zullen meerdere biotopen een rol spelen waar in de experimenten geen rekening mee gehouden kan worden. Tot slot beschermen de secreta van de vogels AIV tegen inactivatie [Swayne et al., 2020]. In een groot deel van de experimenten zijn de materialen gespiked met opgekweekte virussen die zonder secreta zijn toegevoegd aan het te onderzoeken materiaal. Kortom, de persistentie van AIV zal in natuurlijke situaties dus mogelijk langer zijn dan in de experimenten wordt aangetoond. 


\section{Referenties}

Dalziel, A.E. et al. Persistence of Low Pathogenic Influenza A Virus in Water: A Systematic Review and Quantitative Meta-Analysis. PLoS One 2016; 11(10): e0161929.

Delogu, M. et al., Italian human and animal integrated influenza surveillance: Human and animal integrated influenza surveillance: a novel sampling approach for an additional transmission way in the aquatic bird reservoir. Ital. J. Public Health 2012; 9: 29-36.

Domanska-Blicharz, K., et al., H5N1 high pathogenicity avian influenza virus survival in different types of water. Avian Dis. 2010; 54(1 Suppl):734-737.

Guan, J. et al., Survival of avian influenza and Newcastle disease viruses in compost and at ambient temperatures based on virus isolation and real-time reverse transcriptase PCR. Avian Dis. 2009; 53(1): 26-33.

Horm S.V. et al. Environment: a potential source of animal and human infection with influenza A (H5N1) virus. Influenza Other Respir Viruses 2012; 6(6): 442-448.

Irwin, C.K. et al., Using the systematic review methodology to evaluate factors that influence the persistence of influenza virus in environmental matrices. Appl. Environ. Microbiol. 2011; 77(3): 10491060.

Karunakaran, A.C., et al., Survivability of highly pathogenic avian influenza virus (H5N1) in naturally preened duck feathers at different temperatures. Transbound. Emerg. Dis. 2019; 66(3): 1306-1313.

Keeler, S.P., Lebarbenchon, C., Stallknecht, D.E. Strain-related variation in the persistence of influenza A virus in three types of water: distilled water, filtered surface water, and intact surface water. Virol. J. 2013; 10: 13-23.

Koch, G. FLURESIST: Studies on Avian Influenza Virus Survival in Poultry Commodities, Poultry Manure and the Environment, 2011.

Kurmi, B., et al. Survivability of Highly Pathogenic Avian Influenza H5N1 Virus in Poultry Faeces at Different Temperatures. Indian J. Virol. 2013; 24(2): 272-277.

Lebarbenchon, C. et al. Viral Replication, Persistence in Water and Genetic Characterization of Two Influenza A Viruses Isolated from Surface Lake Water. PLoS ONE 2011; 6(10): e26566.

Lu, H. et al. Survival of Avian Influenza Virus H7N2 in SPF Chickens and Their Environments. Avian Dis. 2003; 47: 1015-1021.

Moher, D. et al. Preferred reporting items for systematic reviews and meta-analyses: the PRISMA statement. PLoS Med. 2009; 6(7): e1000097.

Nazir, J. et al., Long-term study on tenacity of avian influenza viruses in water (distilled water, normal saline, and surface water) at different temperatures. Avian Dis. 2010; 54(1 Suppl): 720-724.

Nazir, J. et al., Persistence of Avian Influenza Viruses in Lake Sediment, Duck Feces, and Duck Meat. Appl. Environm. Microbiol. 2011; 77(14): 4981-4985.

Quinn, P.J., Carter, M.E., Donnelly, W.J., Leonard, F.C. Chapter 48: Nature, structure and taxonomy of viruses. In: Veterinary Microbiology and Microbial Disease, 2002.

Swayne, D.E., Suarez, D.L., Sims, L.D. Influenza, in Diseases of Poultry, 2020: 210-256.

Shahid, M.A., et al., Avian influenza virus (H5N1); effects of physico-chemical factors on its survival. Virol. J., 2009; 6:38.

Stallknecht D.E. et al., Avian influenza virus in aquatic habitats: what do we need to learn? Avian Dis. 2010; 54(1 Suppl): 461-465.

Tiwari, A. et al. Survival of two avian respiratory viruses on porous and nonporous surfaces. Avian Dis. 2006; 50(2): 284-287.

Wood, J.P., et al., Environmental persistence of a highly pathogenic avian influenza (H5N1) virus. Environ Sci Technol, 2010. 44(19): p. 7515-20.

Yamamoto, Y. et al., Persistence of avian influenza virus ( $\mathrm{H} 5 \mathrm{~N} 1)$ in feathers detached from bodies of infected domestic ducks. Appl. Environ. Microbiol. 2010; 76(16): 5496-5499.

Yamamoto, Y., Nakamura, K., Mase, M. Survival of Highly Pathogenic Avian Influenza H5N1 Virus in Tissues Derived from Experimentally Infected Chickens. Appl. Environ. Microbiol. 2017; 83(16): e00604-17. 
Zarkov, I.S., Urumova, V.S. Effects of humidity and temperature on avian influenza virus H6N2 persistence in faecal samples from experimentally infected ducks (Anas plathyrhynchos). Rev. Med. Vet. $2013 ; 164$ (7): 343-347.

Zhang, H., et al., Perpetuation of H5N1 and H9N2 avian influenza viruses in natural water bodies. J. Gen. Virol. 2014; 95(7): 1430-1435. 


\title{
6 Kan Wilde eendenmest met aangehecht AIV als stof vervliegen en zich daardoor via de lucht over relatief grote afstanden verspreiden?
}

\author{
6.1 Inleiding
}

Analyse van de HPAI subtype H7N7 epidemie in Nederland toonde aan dat verspreiding van het virus van bedrijf naar bedrijf via de lucht kan hebben plaatsgevonden [Ssematimba et al., 2013; Ypma et al., 2013]. Op besmette bedrijven produceert het geïnfecteerde pluimvee een aanzienlijke hoeveelheid virus dat tot het moment van ruiming via het ventilatiesysteem continue vanuit de stal naar buiten wordt gebracht. Recentelijk zijn in de Verenigde Staten van Amerika (VS) luchtmonsters genomen bij HPAI H5N2 uitbraken. RNA van het virus is gedetecteerd tot 1000 meter van een besmet bedrijf, en tot $70 \mathrm{~m}$ kon het virus zelfs nog geïsoleerd worden [Torremorell et al., 2016]. Ook tijdens de HPAI H5N8 epidemie in Frankrijk werd RNA van het virus op alle vijf bemonsterde bedrijven in luchtmonsters van de stal, in de buurt van de ventilatoren en op 5 meter afstand van de stal gedetecteerd. Op drie van de vijf bedrijven werd tevens op 50-110 meter afstand van de stal RNA van het virus gedetecteerd in luchtmonsters [Scoizec et al., 2018]. N.B. dat het RNA van een virus wordt aangetoond met een PCR-techniek (dat wil zeggen dat aanwezigheid van het virus is aangetoond, maar je weet dan nog niet of het virus levend of dood is), wil dan nog niet zeggen dat dit virus dan levensvatbaar is en een infectie kan veroorzaken.

Zowel in Nederland, de VS als in Frankrijk ging het om grootschalige virusproductie door grote aantallen besmet pluimvee in stallen tijdens een epidemie, waardoor verspreiding van bedrijf naar bedrijf kon optreden. Dat is van een volstrekt andere orde van grootte dan de hypothetische mogelijkheid dat AIV vanuit enkele uitwerpselen van besmette wilde vogels in de omgeving van een pluimveestal - na verstoffing van de uitwerpselen - in de lucht komt en via de luchtinlaat in de stal terecht zou kunnen komen (wilde vogel naar bedrijf verspreiding).

Het doel van dit hoofdstuk is om door middel van onderzoek onder praktijkomstandigheden uit te zoeken of Wilde eendenmest in de vogelgriep-risicoperiode zou kunnen opdrogen en vervliegen tot stof, waardoor er de mogelijkheid zou kunnen bestaan dat Wilde eendenmest als stof zou kunnen worden getransporteerd over relatief grote afstanden via de lucht (wilde vogel naar bedrijf verspreiding).

\subsubsection{Mogelijkheid tot verstoffen van Wilde eendenmest}

Om mest een transitie te laten doormaken naar droge stof, waardoor het in potentie kan gaan vervliegen en door de wind kan worden getransporteerd, moet het vochtgehalte zeer sterk afnemen [Jones \& Harrison, 2004]. In de literatuur zijn er slechts schaarse meldingen over het vochtgehalte van verse mest van wilde eenden. Kear [1963] stelde bij een veldonderzoek in het Verenigd Koninkrijk vast dat verse mest van Smienten (Anas penelope) een vochtgehalte had van ca. 85\%. Purcell [1999] stelde in een veldonderzoek in Canada vast dat verse mest van wilde eenden (Anas plathyrhynchos) een vochtgehalte had van ca. 77\%; Nnaji [2014] maakte gebruik van verse mestmonsters van wilde eenden (Anas plathyrhynchos) met een vochtgehalte van $75 \%$ in een experiment om het gebruik van eendenmest als voedsel voor vissen in aquacultuur te onderzoeken. Over het vochtgehalte van verse mest van gehouden pluimvee is meer bekend. Het gemiddelde vochtgehalte van verse mest van leghennen is ca. $75 \%-85 \%$ [Anderson \& Hill, 
1968; Fernandes et al., 1994; ASG, 2004; Mercia, 2001; Li et al., 2020]. Het gemiddelde vochtgehalte van verse mest van vleeskuikens lijkt met gemiddeld 60-70\% lager dan dat van eenden [Kerstens, 1964 ]. Om als vogelmest te verstoffen en daarmee de mogelijkheid te krijgen om te kunnen vervliegen, moet het vochtgehalte van de vogelmest sterk afnemen. Ritz et al. [2005], Muhktar \& Auvermann [2009] en Singh [2019] geven aan dat het vochtgehalte van de mest moet dalen tot minimaal $10-15 \%$ voordat mest zo droog wordt dat het kan verstoffen.

Daarnaast moet er de nodige windsnelheid zijn om stof te kunnen verplaatsen. Turnbull et al. [1998] onderzochten de concentratie van aerosolen van miltvuurbacteriën (Bacillus anthracis) benedenwinds van plekken die gecontamineerd waren door met miltvuur besmette karkassen. Sporen van miltvuurbacteriën werden alleen waargenomen in luchtmonsters bij winsnelheden vanaf 3 tot 5 meter/seconde (10 - 15 $\mathrm{km} / \mathrm{uur}$ ), wat overeenkomt met windkracht 2 tot 3 op de schaal van Beaufort. Klimatologische omstandigheden zijn bepalend voor de juiste condities voor transport van stof: Holmen et al. [2001] lieten zien dat emissie van stof bij agrarische activiteiten sterk werd vergroot als de relatieve vochtigheid van de lucht beneden de $40 \% \mathrm{kwam}$, en de vochtigheid van de grond werd gereduceerd tot $<3 \%$, en het verschil in temperatuur gemeten op 1 en 7 meter boven de grond meer was dan $1,5^{\circ} \mathrm{C}$.

Clausnitzer \& Singer [2000] vonden dat de concentratie van inhaleerbaar stof ( $<4 \mu \mathrm{m}$ diameter) werd gereduceerd als machtsfunctie, wanneer het vochtgehalte van de grond toenam; en de concentratie inhaleerbaar stof toenam als machtsfunctie, wanneer de temperatuur toenam.

\subsection{Veldonderzoek}

\subsubsection{Methode}

Gedurende de risicoperiode van AI (oktober - maart 2020) zijn mestmonsters van Smienten (Anas penelope) en Wilde eenden (Anas plathyrhynchos) verzameld uit het veld om het vochtgehalte van de mest te bepalen. Mestmonsters van Smienten werden in week 2 t/m 13 van 2020 om de drie weken verzameld (op aanwijzing en met hulp van Roy Slaterus van Sovon, Nijmegen) bij de Nekkeveld polder nabij Nijkerk. In deze polder zijn grote aggregaties van Smienten aanwezig gedurende de vogelgrieprisicoperiode (Figuur 4). Daarnaast zijn om de drie weken mestmonsters (in week $2 \mathrm{t} / \mathrm{m} 10$ van 2020; er waren geen mestmonsters voor week $11 \mathrm{t} / \mathrm{m} 13$ voorradig) van Wilde eenden verzameld bij een stadsplantsoen in Harderwijk (Figuur 5).

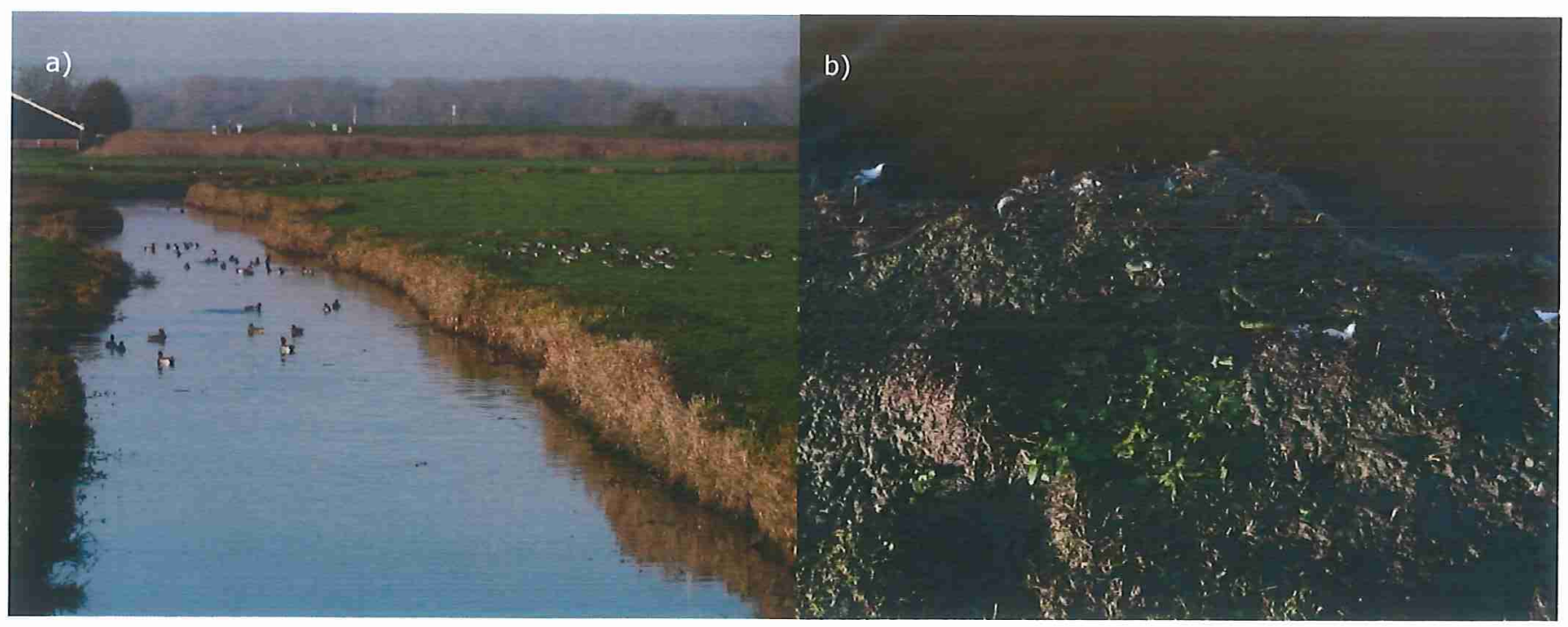


Figuur 4 a) Aggregatie van smienten (Anas penelope) en b) mest van smienten langs sloot in de Nekkeveld polder, Nijkerk (Januari 2020).

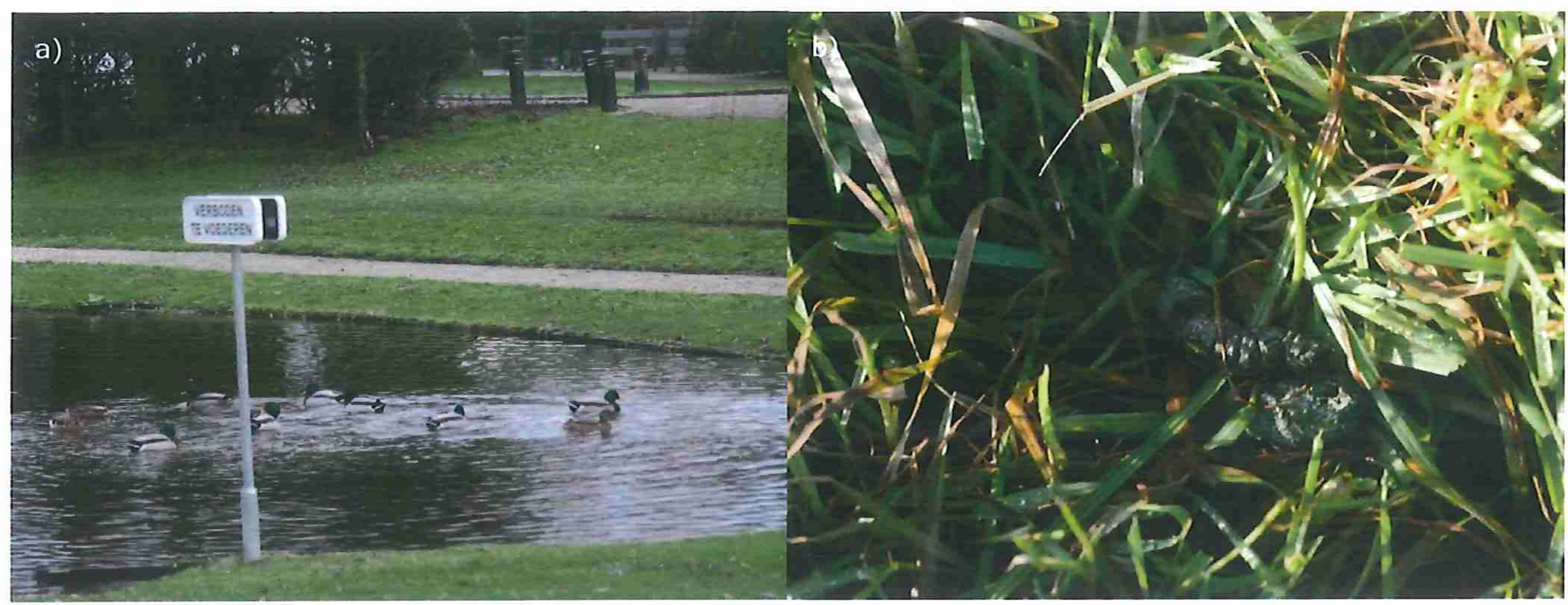

Figuur 5 a) Wilde eenden (Anas plathyrhynchos) en b) mest van Wilde eenden in het stadsplantsoen in Hardwijk (Januari 2020).

De mestmonsters werden verzameld langs de slootkanten van weiden waarin grote aggregaties van Smienten aanwezig waren. De individuele mestmonsters werden op een plastic verzamelbord gelegd, en binnen een uur na verzamelen per auto bij omgevingstemperatuur naar Lelystad gebracht, alwaar zij op een achteraf terrein op het complex van WBVR (onderzoeklocatie) in de buitenlucht werden gedeponeerd op twee verschillende ondergronden: a) op een betonnen ondergrond, gemaakt van standaard betonnen tegels, als proxy voor een betonnen verharding rondom de stal van een pluimveeberdrijf; b) op gras, als proxy voor het weide/grasgebied in de buurt van een pluimveebedrijf.

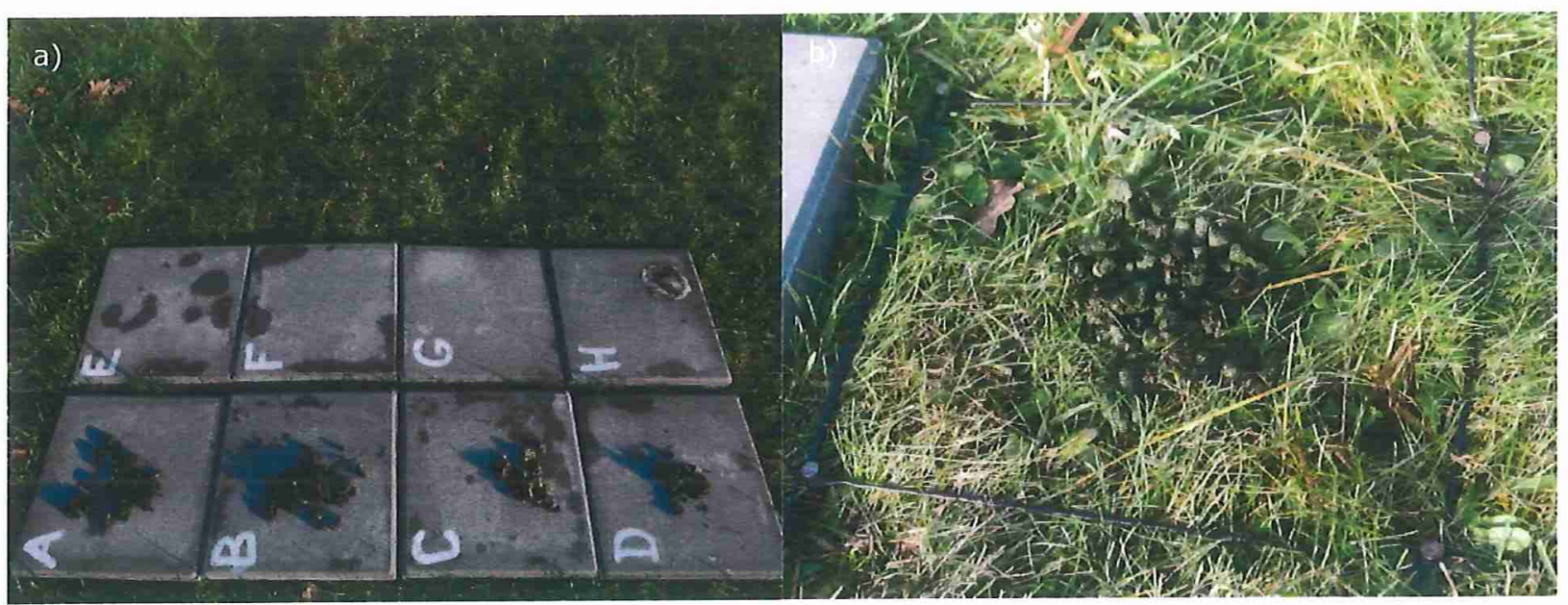

Figuur 6 Smient- en Wilde eend mestmonsters op a) betonnen ondergrond en $b$ ) grasondergrond op de onderzoekslocatie bij WBVR (Januari 2020). 
Wekelijks werd het vochtgehalte bepaald van één van de mestmonsters van de onderzoeklocatie. Daartoe werd het mestmonster in twee gelijke porties verdeeld (ca. 0,5-1,0 gram per stuk), dit werd gewogen in glazen weegpotten en vervolgens werd dit in een oven onder vacuüm $(<2.5 \mathrm{kPa}$ ) gedurende minimaal 3 uur gedroogd bij $60^{\circ} \pm 3^{\circ} \mathrm{C}$. Deze diagnostiek is op basis van analysevoorschrift LAB-001: Determination of residual moisture; documentcode: 00-14-1753 (Referentiedocumenten:

- Supplemental Assay Method for the determination of residual moisture in veterinary biological products, USDA, APHIS, CVB-L (SAM 502.01);

- Determination of moisture content in desiccated biological products (code of Federal regulations, Title 9 - Animals and Animal products, part 113 - Standard requirements, section 113.29 (9-CFR113.29)

- Testing of residual moisture (VICH GL26)).
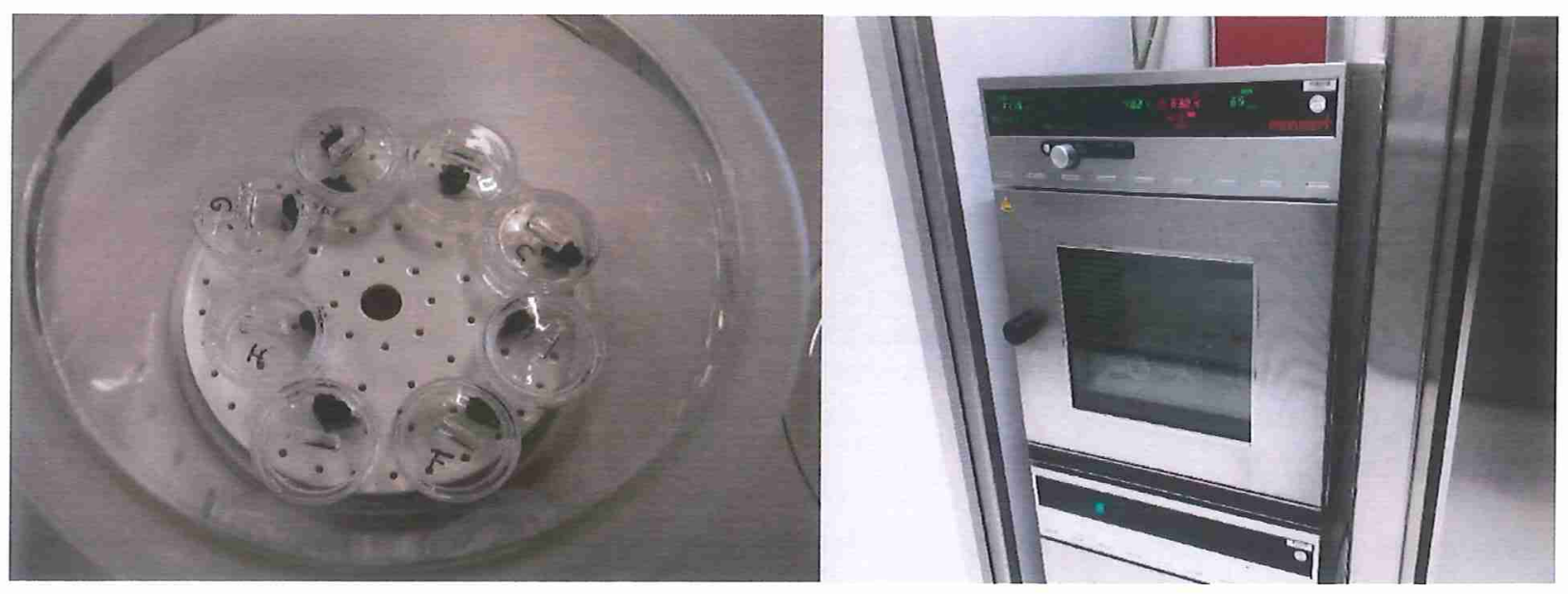

Figuur 7 Mestmonsters in weegpotten (links); drogen van mestmonsters onder vacuüm $(<2.5 \mathrm{kPa})$ bij $60^{\circ} \pm 3^{\circ} \mathrm{C}$ (rechts).

\subsection{Resultaten}

Gedurende het onderzoek, in de periode januari - maart en oktober - december 2020, werden de klimatologische omstandigheden gekenmerkt door regelmatige en langdurige regenbuien, waardoor de mestmonsters zich een groot deel van de tijd in een natte omgeving en op een natte ondergrond bevonden. Alleen in de laatste weken van het voorjaar (week 11-13) was er geen neerslag en was er meer zonneinstraling in vergelijking met de voorgaande weken (Figuur 8). Het vochtgehalte van de mestmonsters van de wilde eenden en de smienten schommelde tussen de ca. 70 en 90\%, waarbij er geen aantoonbaar verschil was tussen beide type ondergronden (Figuur 9 en 10). Alleen in week 12 en 13 van de meetperiode, de periode zonder neerslag, is een verschil in effect van de ondergrond aangetoond op het vochtgehalte van de mest: op beton trad een sterke indroging van de mest op (vochtpercentage mest $23 \%$ in week 12 , en $8 \%$ in week 13), terwijl op het gras nauwelijks indroging waarneembaar was (Figuur 9). 

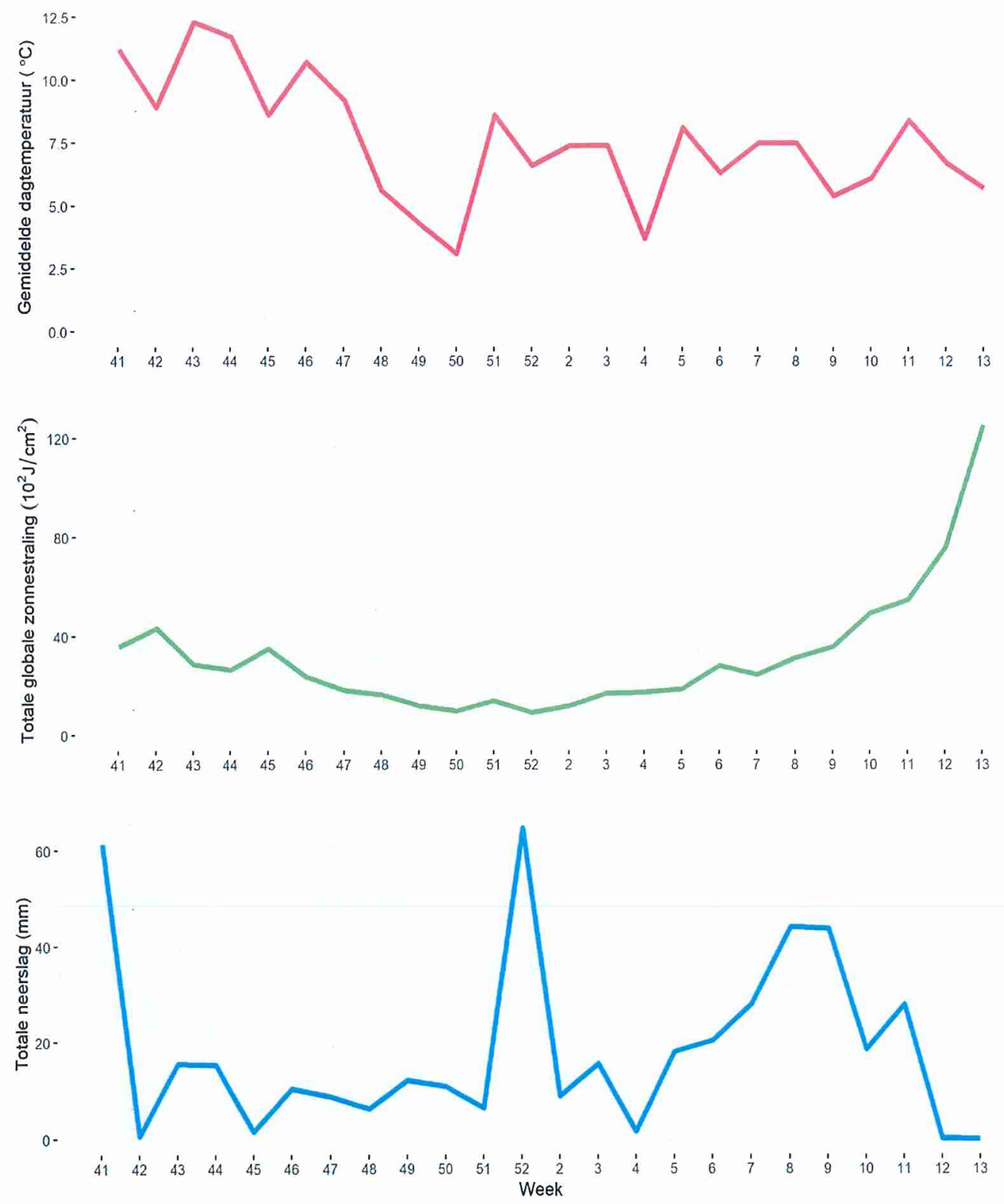

Figuur 8 Gemiddelde dagtemperatuur, totale globale zonne-instraling en totale neerslag in week $2 \mathrm{t} / \mathrm{m} 13$ en week $41 \mathrm{t} / \mathrm{m} 52$ van 2020 (bron: KNMI; meetstation Lelystad). 


\section{Smient}

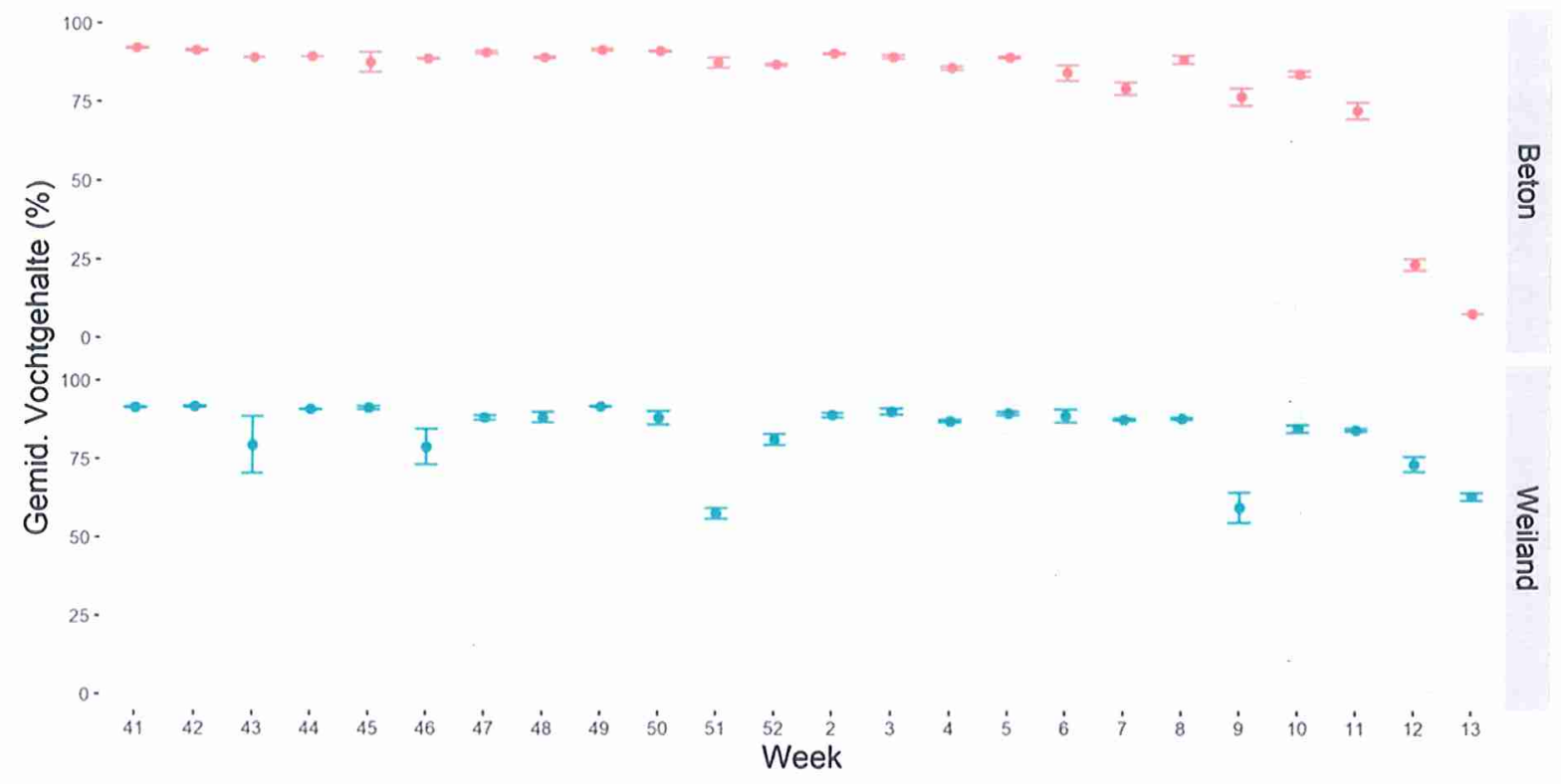

Figuur 9 Gemiddeld vochtgehalte ( \pm s.d.) van mestmonsters van Smienten (Anas penelope) in week 2 t/m 13 en week 41 t/m 52 van 2020 op twee verschillend ondergronden (beton en gras) in de buitenlucht.

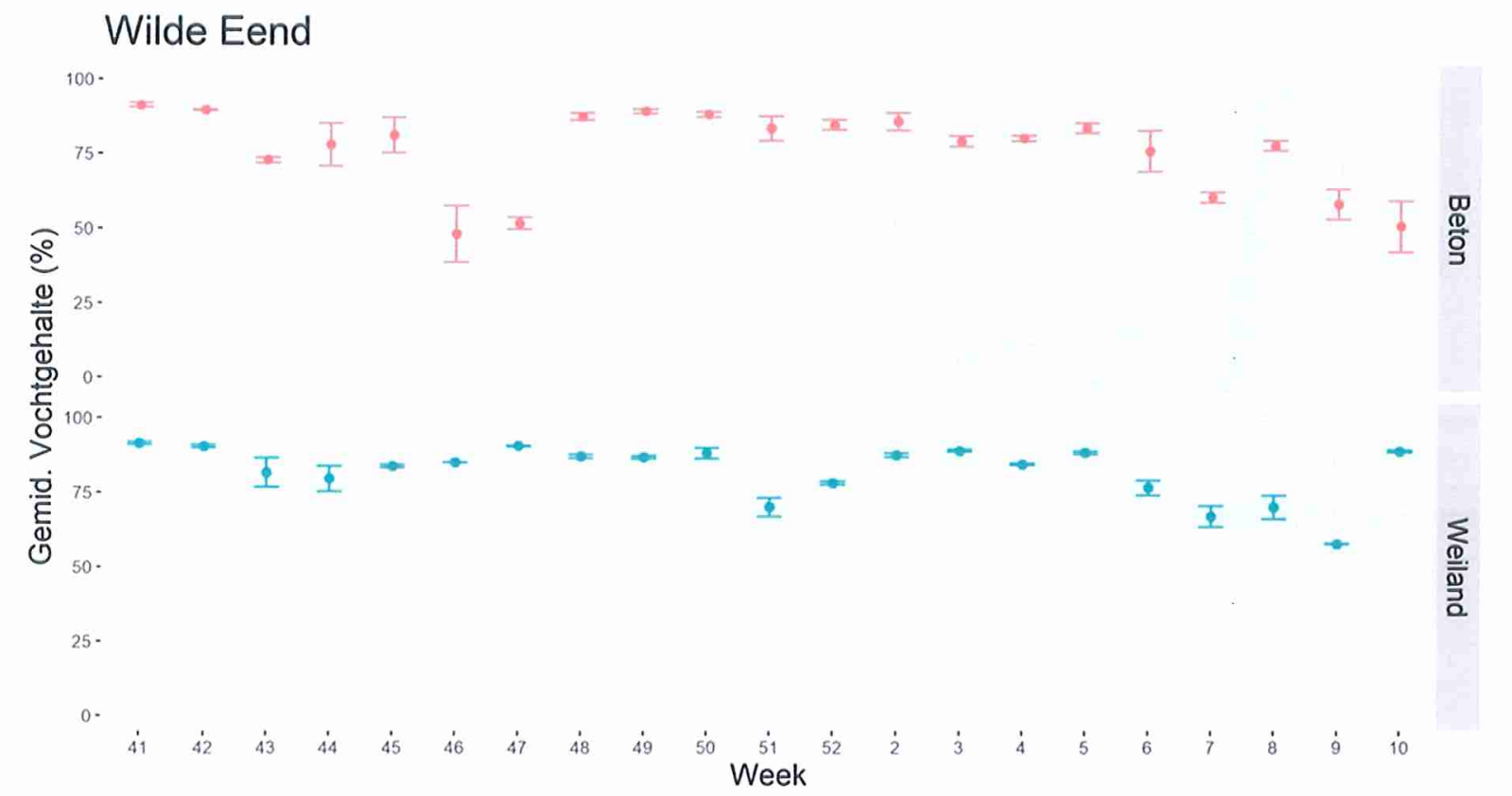

Figuur 10 Gemiddeld vochtgehalte ( \pm s.d.) van mestmonsters van Wilde eenden (Anas plathyrhynchos) in week $2 \mathrm{t} / \mathrm{m} 10$ en week $41 \mathrm{t} / \mathrm{m} 52$ van 2020 op twee verschillend ondergronden (beton en weiland) gedeponeerd in de buitenlucht. 
Zarkov en Urumova (2013) hebben een experiment uitgevoerd naar de persistentie van LPAIV onder invloed van relatieve vochtigheid en temperatuur, maar waarbij tevens de vochtigheid van de mest is meegenomen in de tijd (en dus invloed van uitdrogen van de mest). Wilde eenden (Anas plathyrhynchos) werden geïnfecteerd met LPAIV subtype $\mathrm{H} 6 \mathrm{~N} 2$. Bij een constante omgevingstemperatuur van $15^{\circ} \mathrm{C}$ en relatieve vochtigheid van de lucht van $60 \%$, verdween de initiële virus titer van $10^{4.0} \mathrm{EID}_{50} / 100 \mu \mathrm{L}$ in de Eendenmest naar 0 EID $50 / 100 \mu \mathrm{L}$ binnen twee dagen. De vochtigheid van de Eendenmest nam in dit traject af tot $20 \%$ van de oorspronkelijke vochtigheid, dus er trad een sterke verdroging op.

\subsection{Conclusie}

De kans op verstoffen van uitwerpselen van Smienten en Wilde eenden in de vogelgriep-risicoperiode in grasweiden of op beton wordt ingeschat als verwaarloosbaar klein. Dit heeft te maken met het feit dat de klimatologische omstandigheden in deze periode zeer nat zijn bij lage temperaturen en lage zonneinstraling. Onder dergelijke weersomstandigheden zal het vochtgehalte van uitwerpselen, die buiten in de natuur (op grasweiden of betonplaten rond de pluimveestal) in de omgeving van pluimveestallen liggen, niet noemenswaardig afnemen (70\%-90\% vochtigheid). Voor het verstoffen van de mest is een vochtgehalte van rond de $10 \%$ benodigd. De kans dat AIV gehecht aan vervliegbare meststofdeeltjes van wilde vogels uit de omgeving via luchttransport in een pluimveestal terecht zullen komen in de vogelgrieprisicoperiode, wordt daarmee ingeschat als verwaarloosbaar (interpretatie: is zo zeldzaam dat het niet de moeite waard is om in overweging te worden genomen). Er zijn daarnaast zeer sterke aanwijzingen dat als de wilde vogelmest zou verdrogen naar een vochtgehalte waarbij vervliegen wel mogelijk wordt, dat het eventuele aanwezige AIV in de eendenmest dan niet meer levensvatbaar is [Zarkov en Urumova, 2013].

\section{Referenties}

Anderson, R.S., Hill, K.J. The interrelationship between food and water intake and egg laying in light hybrid hens. Proc. Nutr. Soc. (5 Oct. 1967), 1968: 3A-4A. Geciteerd in: Leeson, S., Summers, J.D., Moran, E.T. Avian water metabolism - a review. World' s Poultry Science Journal 1976; 32(2): 185195. https://doi.org/10.1079/WPS19760003.

Animal Science Group, Wageningen Universiteit. Handboek Pluimveehouderij. 2004.

Clausnitzer, H., Singer, M.J. Environmental influences on respirable dust production from agricultural operations in California. Atmos. Environ. 2000; 34: 1739-1745.

Holmen, B.A., James, T.A., Ashbaugh, L.L., Flocchini, R.G. Lidar-assisted measurement of PM10 emissions from agricultural tilling in California's San Joaquin Valley. Part II: emission factors. Atmos. Environ. 2001; 35: 3265-3277.

Jones, A.M., Harrison, R.M. The effects of meteorological factors on atmospheric bioaerosol concentrations - a review. Science of the Total Environment 2004; 326: 151-180.

Kear, J. The agricultural importance of wild goose droppings. 1963; Available from: https://wildfowl.wwt.org.uk/index.php/wildfowl/article/view/203; geraadpleegd op 29 Juni 2020.

Kerstens, R. Investigation of the production of heat and water vapour and the influence of environment on the growth rate of broiler chicks. Funki Information, Funki Ltd., Aarhus, Denmark, 1964. Geciteerd in: Leeson, S., Summers, J.D., Moran, E.T. Avian water metabolism - a review. World' s Poultry Science Journal 1976; 32(2): 185-195. https://doi.org/10.1079/WPS19760003.

$\mathrm{Li}, \mathrm{X} ., \mathrm{B} . \mathrm{Li}$, and Q. Tong, The Effect of Drying Temperature on Nitrogen Loss and Pathogen Removal in Laying Hen Manure. Sustainability, 2020; 12: 403. 
Mercia, L.S., Vermont, USA, 2001. Geciteerd in: Henuk, Y.L., Dingle, J.G. Poultry manure: source of fertilizer, fuel and feed. World's Poultry Science Journal 2003; 59: 350-360. https://doi.org/10.1079/WPS20030022.

Muhktar, S., Auvermann, B.W. Improving the Air Quality of Animal Feeding Operations with Proper Facility and Manure Management. 2009; Available from:

https://agrilifeextension.tamu.edu/library/ranching/improving-the-air-quality-of-animal-feedingoperations-with-proper-facility-and-manure-management/.

Nnaji, J. Physico-Chemical Quality and Plankton Density of Water in Duck-Fish Production Systems. American Chemical Science Journal 2014; 4: 975-982.

Purcell, S.L., The significance of waterfowl feces as a source of nutrients to algae in a prairie wetland. MSc Thesis, University of Manitoba, Winnipeg, Canada, 1999.

Ritz, C.W., Fairchild, B.D., Lacy, M.P. Litter Quality and Broiler Performance. 2005; Available from: https://thepoultrysite.com/articles/litter-quality-and-broiler-performance.

Scoizec, A., et al. Airborne Detection of H5N8 Highly Pathogenic Avian Influenza Virus Genome in Poultry Farms, France. Front. Vet. Sci. 2018; 5: 15. doi: 10.3389/fvets.2018.00015.

Singh, R. Care of commercial poultry during rainy season. 2019; Available from: http://www.pashudhanpraharee.com/care-of-commercial-poultry-during-rainy-season/

Ssematimba, A. et al. Avian influenza transmission risks: analysis of biosecurity measures and contact structure in Dutch poultry farming. Prev. Vet. Med. 2013; 109(1-2): 106-115.

Torremorell M. et al., Investigation into the Airborne Dissemination of H5N2 Highly Pathogenic Avian Influenza Virus During the 2015 Spring Outbreaks in the Midwestern United States. Avian Dis. 2016; 60(3): 637-643.

Turnbull, P.C.B., Lindeque, P.M., Le Roux, J., Bennett, A.M., Parks, S.R. Airborne movement of anthrax spores from carcass sites in the Ethosha National Park, Namibia. J. Appl. Microbiol. 1998; 84: 667676.

Ypma, R.J. et al. Genetic data provide evidence for wind-mediated transmission of highly pathogenic avian influenza. J. Infect. Dis. 2013; 207(5): 730-735.

Zarkov, I.S., Urumova, V.S. Effects of humidity and temperature on avian influenza virus H6N2 persistence in faecal samples from experimentally infected ducks (Anas plathyrhynchos). Rev. Med. Vet. $2013 ; 164$ (7): 343-347. 


\section{Aerosol transmissie van influenza A virus}

\subsection{Inleiding}

Een aerosol is een suspensie van vaste of vloeibare partikels in lucht (of een gas), die klein genoeg zijn om in de lucht te zweven voor lange periodes vanwege hun lage neerslagsnelheid [Tellier, 2006]. Met een aerosol wordt dus niet virus dat aan meststofdeeltjes door de lucht kunnen worden verspreid bedoeld [Spekreijse et al., 2013]. Partikels met een diameter van $100 \mu \mathrm{m}$ blijven 10 seconden in de lucht hangen voordat ze neerslaan, partikels met een diameter van $20 \mu \mathrm{m}$ blijven vier minuten in de lucht hangen voordat ze neerslaan, partikels met een diameter van $10 \mu \mathrm{m}$ doen er 17 minuten over, en partikels met een diameter van $5 \mu \mathrm{m}$ doen er gemiddeld 62 minuten over. Partikels met een diameter $<5 \mu \mathrm{m}$ slaan in principe niet neer en blijven zweven [Knight, 1980], en worden aangeduid als aerosol. Meststofdeeltjes van vogels zijn veel groter zijn dan wat onder de definitie van aerosol valt.

Het pad waarlangs transmissie van een ziektekiem kan plaatsvinden via een aerosol bestaat uit 3 stappen [Knight, 1980]: a) er moet een aerosol gemaakt worden waarin het agens (in dit geval influenza A virus) aanwezig is, d.w.z. er moet een "ontsnapping" plaatsvinden vanaf een bron; b) het agens moet in de aerosol worden getransporteerd naar vatbare personen/dieren, waarbij het virus lang genoeg moet persisteren in voldoende concentratie tijdens het transport om de infectie over te kunnen brengen; en c) inhalatie van de aerosol door vatbare personen/dieren (het landen van het agens op het doel).

Onderzoek naar aerosol transmissie van Influenza A virus heeft merendeels plaats gevonden bij de mens. Voor een deel van dat onderzoek werd gebruik gemaakt van experimenten waarbij proefdieren worden gebruikt zoals b.v. cavia's.

Hoesten en niezen bij de mens produceert druppels vloeistof die variëren in grootte van minder dan 1 tot $2000 \mu \mathrm{m}$ [Weber \& Stilianakis, 2008]. Deeltjes groter dan $10 \mu \mathrm{m}$ bevatten meer dan $99.9 \%$ van het volume van de aerogene uitstoot, en daarmee ook dezelfde proportie van virushoeveelheid in een hoest of nies. De inhaleerbaarheid van deeltjes voor een vatbaar individu ligt ver beneden de $30 \%$ voor deeltjes $>50$ $\mu \mathrm{m}$. Dat betekent dat de meeste pathogenen zoals influenza virus via niezen of hoesten worden geproduceerd in grotere druppeltjes die niet beschikbaar zijn voor inhalatie: of omdat ze te groot zijn of omdat ze door hun gewicht zeer snel na uitstoten neerslaan. Voor de mens wordt aangegeven dat deeltjes $>10 \mu \mathrm{m}$ niet worden geïnhaleerd en dus niet worden afgezet in de longen. De grotere deeltjes kunnen wel bij het hoesten of niezen van een persoon direct terecht komen op de slijmvliezen van de neus of het oog van een andere persoon die zich op korte tot zeer korte afstand bevindt van de aanhoestende/aanniezende persoon. Een vatbare menselijke persoon heeft daarom het hoogste risico op blootstelling aan een respiratoire infectie wanneer hij of zij zich op korte afstand $(20-50 \mathrm{~cm})$ van een geïnfecteerd persoon bevindt [Chen et al., 2020].

Zeer recent, als gevolg van Covid-19 epidemie, is er veel aandacht geweest voor de transmissie van het Coronavirus via aerosolen [Morawska et al., 2021]. In vergelijking met water- en voedselgerelateerde infecties is er tot nu toe relatief weinig onderzoek gedaan naar respiratoire infecties via aerosolen. Hoewel het evident is dat de hoogste blootstelling voor een individu aan Covid-19 virus plaats vindt op korte afstand van een besmet iemand, er ook duidelijke aanwijzingen zijn dat Covid-19 infecties in gemeenschappen plaatvinden op grotere afstanden tussen individuen door inhalatie van aerosolen met daarin virusdeeltjes in afgesloten ruimten (met onvoldoende ventilatie) die worden gedeeld met geïnfecteerde individuen. Preventie van dergelijke infecties in gebouwen ligt met name in voldoende ventilatie, d.w.z. een aanzienlijke hoeveelheid buitenlucht, die wordt gecombineerd met gerecirculeerde binnenlucht die wordt gereinigd door filtratie en desinfectie. Ventilatie, en daarmee sterke verdunning van aanwezige virusdeeltjes in aerosolen, is dus een uiterst belangrijke preventieve maatregel.

Pluimvee raakt geïnfecteerd met AI virus als ze voldoende infectieus virus binnen krijgen. Dat kan via de respiratoire en orale route maar ook via b.v. het oogslijmvlies. Zoals eerder aangegeven beperken wij ons in deze studie tot de respiratoire route. In het verleden hebben sommige pluimveehouders aangegeven dat 'vogelgriep waarschijnlijk via de ventilatie binnen is gekomen' [Pluimveeweb, jan. 2021], daarbij een relatie leggend met transmissie van AIV via de lucht. AIV wordt door geïnfecteerde vogels uitgescheiden 
via de neus, mond, oogslijmvliezen, en cloaca [Swayne et al., 2020]. Door geïnfecteerde vogels geproduceerd AIV kan in een aerosol terecht komen via de uitgeademde lucht en door proesten [Falk \& Hunt, 1980]. Zo gauw AIV in een aerosol door een geïnfecteerde wilde vogel wordt geproduceerd, staat het bloot aan biologische en fysieke afbraak. Lucht is in principe niet een geschikte of gunstige omgeving voor virussen om in te overleven [Falk \& Hunt, 1980].

Het doel van dit hoofdstuk is om de literatuur aangaande aerosol transmissie van influenza A virus, inactivatie van het virus in een aerosol, schatten van benedenwindse concentratie van het virus in pluimmodellen en transmissie experimenten met AIV bij pluimvee te bundelen om daarmee beter inzicht te krijgen in de mogelijke wilde-vogel-naar-bedrijf-verspreiding via aerosolen.

\subsection{Inactivatie van influenza A virus in een aerosol}

De fysieke afbraak van agentia in de aerosolen is afhankelijk van de tijd die deeltjes in de aerosol zijn opgelost, dat wordt beïnvloedt door de deeltjesgrootte en neerslagprocessen. Hoe meer hygroscopisch een deeltje in de aerosol is, hoe groter een deeltje wordt in grootte in een vochtige omgeving en hoe sneller er neerslag van de deeltjes plaats vindt [Staerk, 1999]. Biologische afbraak van het agens (virus/bacterie etc.) in de aerosol na vrijkomen vanaf een bron omvat factoren die invloed hebben op de overleving (de mogelijkheid om te repliceren) en infectiviteit (de mogelijkheid om infectie te veroorzaken) van het virus, waaronder relatieve of absolute vochtigheid, temperatuur, licht (UV-straling), en ionisatie van de lucht [Lighthart \& Frisch, 1976].

Een belangrijke factor bij biologische afbraak van influenza $A$ virus in een aerosol is verandering in vochtigheid van de lucht. Influenza A virussen bevatten structurele lipiden, en virussen met een lipidestructuur overleven het beste in droge lucht ( $<50 \%$ relatieve vochtigheid). Lipide-vrije virussen zoals b.v. het mond-en-klauwzeer (MKZ) virus, zijn het meest stabiel in vochtige lucht [Weber \& Stilianakis, 2008; Tang, 2009]. Relatieve vochtigheid (RV) beschrijft de hoeveelheid waterdamp die in de lucht wordt vastgehouden bij een specifieke temperatuur, relatief tot de maximale hoeveelheid waterdamp die lucht bij die temperatuur mogelijk kan vasthouden. Bij hoge temperaturen kan lucht veel meer waterdamp vasthouden dan bij lage temperaturen. Zo bevat lucht bij een temperatuur van $20{ }^{\circ} \mathrm{C}$ met een RV van $50 \%$, aanmerkelijk meer vocht dan lucht bij $5{ }^{\circ} \mathrm{C}$ en een RV van $50 \%$. Het onderzoek naar het effect van RV en temperatuur op het overleven van Influenza A virus in aerosolen liet in de meeste gevallen zien dat het virus in de aerosol het beste overleeft bij lage RV (20-30\%) en geïnactiveerd wordt bij medium (40$60 \%$ ) en hoge RV (>60\%) [Hemmes et al., 1960; Hood, 1963; Harper, 1961]. Aerosol experimenten in een cavia-model lieten zien dat zowel koude $\left(5^{\circ} \mathrm{C}\right)$ als droge condities $(20-35 \% \mathrm{RV})$ transmissie van influenza A virus bevorderen [Lowen et al., 2007]. Bij een temperatuur van $20^{\circ} \mathrm{C}$ en bij lage RV (20-35\%), is transmissie van influenza A virus is zeer efficiënt; bij een RV van 50\%, kon er beperkte transmissie ( $25 \%$ van naïeve dieren werd geïnfecteerd) worden gemeten; bij $80 \%$ RV kon er geen transmissie meer worden gemeten tussen hokken met cavia's.

N.B. men moet zich realiseren dat dergelijke experimenten zijn gedaan met cavia's in hokjes die op zeer korte afstand staan van elkaar (15 cm afstand) waarbij er een geforceerde luchtstroom werd gecreëerd tussen de hokjes om influenza virus deeltjes over zeer korte afstand te laten bewegen. Shaman \& Kohn [2009] richtten zich op de absolute vochtigheid (AV) i.p.v. de relatieve vochtigheid (RV) van de lucht. AV, dus het actuele vochtgehalte van lucht onafhankelijk van de temperatuur, kan van een nog grotere biologische significantie zijn voor de overleving en transmissie van agentia dan RV [Shaman \& Kohn, 2009]. Met het herbestuderen van de experimenten uit het verleden m.b.t. RV kwamen zij tot de conclusie dat AV zowel de overleving als transmissie van influenza A virus sterker beïnvloeden van RV: $50 \%$ van de variabiliteit in transmissie en $90 \%$ van de variabiliteit in overleving van het virus worden verklaard door AV. Daarmee wordt duidelijk dat een hoge AV de transmissie en overleving van influenza A virus sterk zal verminderen. Voor de humane situatie bevelen zij daarom aan om op plekken waar transmissie van influenza A virus tot complicaties kunnen leiden, zoals de intensive-care unit in ziekenhuizen en bij verpleeghuizen, de lucht sterk te bevochtigen met externe luchtbevochtigers. Het meest recente onderzoek naar invloed van luchtvochtigheid op overleving en transmissie van influenza virus laat zien dat de combinatie van temperatuur en RV een even valide voorspeller is van de overleving en transmissie van influenza A virus als AV [Marr et al., 2018]. 
Temperatuur is een belangrijke factor m.b.t. de overleving van het virus, omdat de snelheid van inactivatie van virale eiwitten, nucleïnezuren en enzymen wordt verhoogd bij stijgende temperatuur [Tang, 2009]. In het algemeen kan gesteld worden dat hoge temperaturen de virus overleving nadelig beïnvloeden en lage temperaturen de overlevingstijd van Influenza A virus verhogen [Harper, 1961; Marr et al., 2018].

Ultraviolette-straling in het zonlicht is een belangrijke natuurlijke, virusremmende factor in de buitenomgeving [Șagripanti \&Lytle, 2007]. In een experiment met Venezuelan equine encephalomyelitis virus (VEEv) werd het effect van gesimuleerde zonnestraling op een aerosol met VEEv onderzocht bij verschillende RV [Berendt \& Dorsey, 1971]: 0,02\% het virus overleefde 1 uur in een ruimte bij 30\% RV, en $0,006 \%$ van het virus overleefde bij 1 uur bij $60 \%$ RV. In de winterperiode is in Europese landen de UV-inactivatie in het algemeen lager dan in de zomer, omdat er duidelijk minder zoninstraling plaats vindt. Echter de mate van inactivatie door UV-straling is in dezelfde orde van grootte als die welke verwacht mag worden door veranderingen in RV [Weber \& Stilianakis, 2008].

Een andere virusremmende factor is gerichte ionisatie van de lucht. Een ionisator creëert elektronen, die de oppervlakte moleculen van deeltjes (b.v. virussen) een negatieve lading geven, waardoor deze deeltjes worden aangetrokken door een positief geladen opvangplaat. De reductie in infectiviteit van het virus in aerosolen als gevolg van ionisatie van de lucht wordt toegeschreven aan eiwit- en lipide peroxidering door de ionisatie. Een onderzoek dat gebruik maakte van een ionisator liet in een experiment met cavia's zien (dieren individueel gehuisvest in hokjes die op $15 \mathrm{~cm}$ afstand van elkaar stonden) dat aerosol transmissie van influenza A virus (Panama 1999 stam) op zeer korte afstand kon worden voorkomen en het virus geïnactiveerd [Hagbom et al., 2015].

\subsection{Schatten van benedenwindse concentratie van agentia in een pluimmodel}

Lighthart \& Frisch [1976] en Lighthart \& Mohr [1987] hebben wiskundige modellen ontwikkeld om vanuit een puntbron benedenwindse concentraties van levensvatbare micro-organismen in aerosolen te schatten bij dynamische atmosferische condities. Het algoritme dat de levensvatbare concentratie van microorganismen schat in benedenwindse richting van een puntbron, bestaat uit de volgende elementen: a) weergegevens (windsnelheid, relatieve vochtigheid, zonestraling); b) berekening van het overleven van virus in een aerosol als functie van atmosferische condities in benedenwindse pluim; c) een schatting van de sterkte van de virusbron; d) berekening van overgebleven levensvatbare virus na deeltjes dispersie, deeltjes neerslag tijdens vervoer en afdoding van het virus. In beide modellen is het VEEv gebruikt als voorbeeld agens, omdat voor dit virus enkele basale gegevens beschikbaar waren uit eerdere experimenten.

Algemene conclusies uit de toepassing van het model zijn dat:

i) buitenlucht treedt op als een sterke verdunningsfactor van het virus op zijn reis naar een doel: op 30 meter afstand van de puntbron waar het virus wordt losgelaten is het virus met een factor van $\pm 10^{5}$ verdund, op een afstand van 50 meter is dit al een verdunningsfactor van \pm $10^{20}$

ii) hogere windsnelheden er voor zorgen dat er minder tijd is voor afsterving van het virus tijdens de reis naar het doel;

iii) als het virus wordt losgelaten bij een puntbron op hoogte (b.v. $200 \mathrm{~m}$ boven de grond), het virus een langere reis kan maken naar het doel in vergelijking met virus dat tussen 10 en 50 $\mathrm{cm}$ boven de grond wordt losgelaten. Wanneer het virus dicht bij het grondoppervlak wordt losgelaten zal het op zijn reis vaker neerslaan als gevolg van botsing met objecten als b.v. struiken, grashalmen etc.. 


\subsection{Transmissie experimenten met aviaire influenza virus in aerosolen}

Tsukamoto et al. [2007] voerden experimentele infecties met een HPAIV subtype H5N1 uit in een isolator met verschillende compartimenten (gescheiden door gaas, afstand tussen de compartimenten was $10 \mathrm{~cm}$ ). Om transmissie met een aerosol van het virus te meten werd een hok met intranasaal-geïnoculeerde kippen (dosis: $10^{7}$ EID50 per kip) naast een hok met vatbare kippen (geen direct contact mogelijk) gezet. In experiment 1 werd één kip geïnoculeerd met het virus en bij vier vatbare kippen gezet in één van de compartimenten (zeg compartiment 1), en in het andere compartiment (compartiment 2; geen direct contact mogelijk met kippen in compartiment 1) werden ook vier vatbare kippen gezet; de geïnoculeerde kip liet kliniek zien en ging na 2 dagen dood. Geen van de direct-contact dieren in het compartiment bij de geïnoculeerde kip (compartiment 1) en geen van de dieren in het andere compartiment (compartiment 2) gingen dood (helaas zijn er geen diagnostische testen uitgevoerd om infectie vast te stellen).

In experiment 2 werden twee kippen geïnoculeerd met het virus en werden er twee vatbare kippen bij gezet in het compartiment (compartiment 1), en in het naastgelegen compartiment (compartiment 2, geen direct contact mogelijk met kippen in compartiment 1) werden weer 4 vatbare kippen gezet. De twee geïnoculeerde kippen gingen na 2 dagen dood, en één van de twee direct-contact kippen in het compartiment (compartiment 1) ging dood, 3 dagen na start experiment. In het naastgelegen compartiment (compartiment 2) gingen geen van de vier vatbare dieren dood. In experiment 3 werden vier kippen geïnoculeerd met het virus en werden er vier vatbare kippen bij gezet in het compartiment (compartiment 1); in het naastgelegen compartiment (compartiment 2, geen direct contact met de kippen in compartiment 1 mogelijk) werden weer vier vatbare kippen gezet. De vier geïnoculeerde kippen in het eerste compartiment gingen na twee dagen dood en de vier direct-contact kippen in hetzelfde compartiment gingen na 3-4 dagen dood. Van de totaal vier vatbare kippen in het naastliggende compartiment (compartiment 2) gingen er drie dood op 4-8 dagen na start van het experiment. Conclusie van het onderzoek was dat er effectieve direct contact-transmissie optreedt als $50 \%$ van de kippen in een compartiment geïnfecteerd werd en dat aerosol-transmissie flink minder effectief is in vergelijking met direct contact-transmissie, ondanks het feit dat er maar $10 \mathrm{~cm}$ afstand zat tussen de twee verschillende compartimenten - gescheiden door gaas - met kippen.

Shi et al. [2010] voerden een experiment uit met een LPAIV subtype H9N2. Een deel van de experimenten was gericht op onderzoek naar mogelijke aerosol-transmissie waarbij een hok met 6 geïnoculeerde kippen (dosis $10^{7}$ EID $_{50}$ per kip) werd gehouden op een afstand van $40 \mathrm{~cm}$ van een ander hok met 6 vatbare kippen (hokken waren van gaas voorzien zodat luchtstroom het andere hok kon bereiken). Er trad virustransmissie op naar het naastliggende hok met vatbare kippen over een afstand van $40 \mathrm{~cm}: 4$ uit 6 van de keelswabs en 2 uit 6 van de cloacaswabs waren positief.

Yao et al. [2011] voerden een experiment uit met een LPAIV subtype H9N2. Ook hier was een deel van het experiment gericht op onderzoek naar mogelijke aerosol transmissie, waarbij een isolator A met 15 geïnoculeerde kippen (dosis $10^{7} \mathrm{ELD}_{50}$ per kip; inoculatie oraal, intranasaal en intratracheaal) was verbonden met een isolator B (verbinding met buis van 1.5 meter met geforceerde ventilatie van isolator A naar isolator B) waar 15 vatbare kippen in verbleven. Het experiment werd twee keer uitgevoerd. Zeven dagen na start van het experiment werden in het eerste en tweede experiment respectievelijk $80 \%$ en $87 \%$ van de vatbare kippen in isolator B besmet. In vergelijking met de eerder genoemde aerosolexperimenten is te zien dat als er een aanzienlijke hoeveelheid virus wordt uitgescheiden (2-3 keer meer geïnfecteerde dieren als uitscheidingsbron) dat het dan mogelijk is een aerosol-transmissie te laten plaatsvinden via geforceerde ventilatie op $1.5 \mathrm{~m}$ afstand.

Een Nederlands experiment bij pluimvee [Spekreijse et al., 2011] liet zien dat kippen die werden blootgesteld - op een afstand van 0,2, 0,4 en 1,1 meter afstand (zonder geforceerde ventilatie) van 
experimenteel HPAI subtype H5N1-geïnfecteerde kippen (dosis $10^{5}$ EID50 per kip) - besmet kunnen raken. Dit gebeurde in 4 van de in totaal 16 experimenten (25\%). Er werden 20 luchtmonsters genomen (twee monsters per dag, gedurende 10 dagen na start van het experiment). Er werden twee luchtmonsters positief bevonden met concentraties van $10^{1.3-1.6}$ EID $_{50}$. De conclusie van de onderzoekers was dat aerosol transmissie over korte afstand kan optreden, maar dat de kans op besmetting laag is, de meeste kippen ontwijken besmetting. Transmissie via aerosolen over grotere afstanden werd ingeschat als een zeer onwaarschijnlijke introductieroute.

\subsection{Conclusie}

Er zijn verschillende processen die de concentratie van Influenza A virus in aerosolen kunnen beïnvloeden:

o Naarmate de RV van de lucht toeneemt (b.v. bij mist), zullen deeltjes in een aerosol qua grootte toenemen en sneller neerslaan;

- Temperatuur en RV zijn goede voorspeller van overleving en transmissie van Influenza A virus in aerosolen: zowel koude $\left(5^{\circ} \mathrm{C}\right)$ als droge condities $(20-35 \% \mathrm{RV})$ bevorderen overleving en transmissie van het virus. Bij een temperatuur van $20^{\circ} \mathrm{C}$ en bij lage RV (20-35\%), is transmissie van het virus zeer efficiënt (cavia-model); bij een RV van $50 \%$, kon er beperkte transmissie worden gemeten; bij $80 \%$ RV kon er geen transmissie meer worden gemeten tussen hokken met cavia's;

- UV straling uit zonlicht verlaagt de overleving van influenza A virus;

- Ionisatie van de lucht verlaagt de overleving van influenza A virus.

Ontwikkelde wiskundige modellen om vanuit een puntbron benedenwindse concentraties van levensvatbare micro-organismen in aerosolen te schatten bij dynamische atmosferische condities laten zien dat er na het loskomen van het virus vanaf een puntbron er zeer sterke verdunning optreedt van het virus in de lucht. Hogere windsnelheden zorgen ervoor dat het virus sneller bij zijn doel aankomt en er minder tijd is voor inactivatie van het virus. Wanneer het virus op hoogte wordt losgelaten, zal het virus een langere reis kunnen maken naar het doel in vergelijking met virus dat tussen 10 en $50 \mathrm{~cm}$ boven de grond wordt losgelaten. Wanneer het virus dicht bij het grondoppervlak wordt losgelaten zal het op zijn reis vaker neerslaan als gevolg van botsing met objecten zoals grashalmen, struiken en bomen.

Transmissie-experimenten met AIV bij pluimvee laten zien dat aerosol transmissie over korte afstand (10 - $40 \mathrm{~cm}$ ) kan optreden, maar dat de kans op besmetting laag is. De kans op transmissie van AIV via aerosolen over grotere afstanden in de buitenlucht wordt ingeschat als verwaarloosbaar als gevolg van de inactivatie van virusdeeltjes in de buitenlucht en met name door de enorme verdunning van eventuele virusdeeltjes in een aerosol in de buitenlucht. Dit kan worden geïnterpreteerd als dat het zo zeldzaam is dat het niet de moeite waard is om in overweging te worden genomen.

\section{Referenties}

Beerens, N., Germeraad, E.A., Venema, S., Verheij, E., Pritz-Verschuren, S.B.E., Gonzales, J.L. Comparative pathogenicity and environmental transmission of recent highly pathogenic avian influenza H5 viruses. Emerg. Microbes \& Infections 2021; 10: 97-108.

Berendt, R.F., Dorsey, E.L. Effect of simulated radiation and sodium fluorescein on the recovery of Venezuelan equine encephalomyelitis virus from aerosols. Appl. Microbiol. 1971; 21 (3): 447-450.

Chen, W., Zhang, N., Wei, J., Yen, H-L., Li, Y. Short-range airborne route dominates exposure of respiratory infection during close contact. Building and Environment 2020; 176: 106859.

Clausnitzer, H., Singer, M.J. Environmental influences on respirable dust production from agricultural operations in California. Atmos. Environ. 2000; 34: 1739-1745. 
Falk, L.A., Hunt, R.D. Overview of airborne contagion in animals. Ann. New York Acad. Sci. 1980; 174178.

Hagbom, M., Nordgren, J., Nybom, R., Hedlund, K-O, Wigzell, H., Svensson, L. Ionizing air affects influenza virus infectivity and prevents airborne-transmission. Sci. Rep. 2015; 5: 11431.

Harper, G.J. Airborne micro-organisms: survival tests with four viruses. J. Hyg. 1961; 59: 479-486.

Health Canada. Routine practices and additional precautions for preventing the transmission of infection in health care: revision of isolation and precaution techniques. Canadian Communicable Disease Report. 1999;25(Suppl4).

Hemmes, J.H., Winkler, K.C., Kool. S.M. Virus survival as a seasonal factor in influenza and poliomyelitis. Nature 1960; 188: 430-431.

Hinshaw, V.S., Webster, R.G. The natural history of influenza A viruses. In: A.S. Beare (editor). Basic and applied influenza research, CRC Press Inc., Boca Raton, Florida, USA, 1982: 79-104.

Holmen, B.A., James, T.A., Ashbaugh, L.L., Flocchini, R.G. Lidar-assisted measurement of PM10 emissions from agricultural tilling in California's San Joaquin Valley. Part II: emission factors. Atmos. Environ. 2001; 35: 3265-3277.

Hood, A.M. Infectivity of influenza virus aerosols. J. Hyg. 1963; 61: 331-335.

Jones, A.M., Harrison, R.M. The effects of meteorological factors on atmospheric bioaerosol concentrations - a review. Science of the Total Environment 2004; 326: 151-180.

Knight, V. Viruses as agents of airborne contagion. Ann. N Y Acad. Sci 1980; 353: 147-156.

Lemieux, C., Brankston, G., Gitterman, L., Hirji, Z., Gardam, M. Questioning aerosol transmission of influenza. Emerg. Infect. Dis. 2007; 13 (1): 173-174.

Lighthart, B., Frisch, A.S. Estimation of viable airborne microbes downwind from a point source. Appl. Environ. Microbiol. 1976; 31(5): 700-704.

Lighthart, B., Mohr, A.J. Estimating downwind concentrations of viable airborne microorganisms in dynamic atmospheric conditions. Appl. Environ. Microbiol. 1987; 53(7): 1580-1583.

Lowen, A.C., Mubareka, S., Steel, J., Palese, P. Influenza virus transmission is dependent on relative humidity and temperature. PLoS Pathog. 2007; 3: 1470-1476.

Marr, L.C., Tang, J.W., Van Mullekom, J., Lakdawala, S.S. Mechanistic insights into the effect of humidity on airborne influenza virus survival, transmission and incidence. J. R. soc. Interface 2019; 16: 20180298. http://dx.doi.org/10.1098/rsif.2018.0298.

Morawska, L. et al.. A paradigm shift to combat indoor respiratory infection. Science 2021; 372 (6543): 689-691.

Pluimveeweb, jan. 2021 (nr. 1). Vogelgriep waarschijnlijk via ventilatie binnegekomen: 20-23.

Sagripanti, J.L., Lytle, C.D. Inactivation of influenza virus by solar radiation. Photochem. Photbiol. 2007; 83: $1278-1282$.

Schaffer, F.L., Soergel, M.E., Straube, D.C. Survival of airborne influenza virus: effects of propagating host, relative humidity and composition of spray fluids. Arch. Virol. 1976; 51: 263-273.

Shaman, J., Kohn, M. Absolute humidity modulates influenza survival, transmission, and seasonality. PNAS 2009; 106(9): 3243-3248.

Shi, H., Ashraf, S., Gao, S., Lu, J., Liu, X. Evaluation of transmission route and replication efficiency of H9N2 avian influenza virus. Avian Dis. 2010; 54(1): 22-27.

Spekreijse, D., Bouma, A., Koch, G., Stegeman, A. Airborne transmission of a highly pathogenic avian influenza virus strain $\mathrm{H} 5 \mathrm{~N} 1$ between groups of chickens quantified in an experimental setting. Vet. Microbiol. 2011; 152: 88-95.

Spekreijse, D., Bouma, A., Koch, G., Stegeman, A. Quantification of dust-borne transmission of highly pathogenic avian influenza virus between chickens. Influenza and other Respiratory viruses 2013; 7(2): 132-138.

Staerk, K.D.C. The role of infectious aerosols in disease transmission in pigs. Vet. J. 1999; 158: 164-181.

Swayne, D.E., Suarez, D.L., Sims, L.D. Influenza. In: Diseases of Poultry, 14th Edition. Ed. D.E.Swayne, John Wiley and Sons, 2020: 210-256.

Tang, J.W. The effect of environmental parameters on the survival of airborne infectious agents. J. R. Soc. Interface 2009; 6: S737-S746. 
Tellier, R. Review of aerosol transmission of Influenza A virus. Emerg. Infect. Dis. 2006; 12 (11): 16571662.

Tsukamoto, K., Imada, T., Tanimura, N, Okamatsu, M., Mase, M., Mizuhara, T., Swayne, D., Yamaguchi, S. Impact of different husbandry conditions on contact and airborne transmission of H5N1 highly pathogenic avian influenza virus to chickens. Avian Dis. 2007; 51(1): 129-132.

Turnbull, P.C.B., Lindeque, P.M., Le Roux, J., Bennett, A.M., Parks, S.R. Airborne movement of anthrax spores from carcass sites in the Ethosha National Park, Namibia. J. Appl. Microbiol. 1998; 84: 667-676.

Weber, T.P., Stilianakis, N.I. Inactivation of influenza A viruses in the environment and modes of transmission: a critical review. Journal of Infection 2008; 57: 361-373.

Weber, T.P., Stilianakis, N.I. A note on the inactivation of influenza A viruses through solar radiation, relative humidity and temperature. Photochem. Photobiol. 2008; 84(6): 1601-1602.

Webster, R.G., Yakhno, M., Hinshaw, V.S., Bean, W.J., Murti, K.G. Intestinal influenza: replication and characterization of influenza viruses in ducks. Virology 1978; 84: 268-278.

Yao, M., Zhang, X., Gao, J., Chai, T., Miao, Z., Ma, W., Qin, M., Li, X., Liu, J., Zhang, H. The occurrence and transmission characteristics of airborne H9N2 avian influenza virus. Berl. Muench. Tieraerztl. Wschr. $2011 ; 124(3 / 4): 136-141$. 


\section{Wat is de infectieuze dosis van AIV in pluimvee?}

\subsection{Inleiding}

Pluimvee raakt geïnfecteerd met AIV als ze voldoende infectieus virus binnen krijgen via inademing of ingestie. Na opname vermeerdert het virus zich eerst op de plaats van binnenkomst, dus in de luchtwegen of het darmkanaal. Na de eerste virusvermeerdering verspreiden HPAIVs zich via het bloed- en lymfesysteem over het lichaam van de gastheer en vermeerderen zich in diverse celtypen in interne organen, hersenen en de huid. Klinische verschijnselen en sterfte door een infectie met HPAI virussen worden veroorzaakt door meervoudige orgaan falen. LPAI virusvermeerdering blijft meestal beperkt tot in de luchtwegen en het darmkanaal, waarbij klinische verschijnselen en eventuele sterfte worden veroorzaakt door schade aan de luchtwegen of door secundaire bacteriële infecties [Swayne et al., 2020]. De virulentie, het vermogen van virussen om ziekte bij een gastheer te veroorzaken, is afhankelijk van het virus en de gastheer en wordt beïnvloed door verschillende factoren, zoals de dosis van het virus en de diersoort, leeftijd en immuunstatus van de gastheer [Quinn et al., 2002].

De virulentie van AI virussen in specifieke diersoorten kan, naast in vitro onderzoeken, worden onderzocht in dierexperimenten. In deze experimenten wordt een gekwantificeerde hoeveelheid virus via een vooraf vastgestelde route toegediend aan een gastheer. Vervolgens worden klinische verschijnselen, mortaliteit en morbiditeit gescoord. Het ontstaan van klinische verschijnselen valt meestal samen met de start van virusuitscheiding [Quinn et al., 2002] via secreta uit neus, mond, conjunctiva of cloaca. Een infectie kan dus worden bevestigd door het meten van virusuitscheiding in swabs van de mondholte, de oppervlakkige luchtwegen en/of de cloaca. Middels het aantonen van afweerstoffen in bloed kan worden bevestigd of een gastheer een infectie met het specifieke virus heeft doorgemaakt. Dankzij het scoren van klinische verschijnselen en het meten van virusuitscheiding in swabs of afweerstoffen in bloed kunnen diverse karakteristieken van het te onderzoeken virus in die diersoort worden bepaald, bijvoorbeeld de duur en mate van virusuitscheiding [Germeraad et al., 2019], de imuunrespons van de gastheer [Cornelissen et al., 2012; Post et al., 2012] en de minimale infectieuze dosis (hoeveelheid virus dat een dier minimaal binnen moet krijgen voor een infectie) [Pantin-Jackwood et al., 2017].

Het doel van dit hoofdstuk is het bepalen van de minimale infectieuze dosis van AIV in pluimvee. Middels een literatuuronderzoek is een dataset gecreëerd. Deze data is geanalyseerd en vervolgens is met een deel van de data een meta-analyse uitgevoerd. In deze meta-analyse wordt de $50 \%$ effectieve dosis, de inoculatie dosis waarbij $50 \%$ van de geïnoculeerde dieren geïnfecteerd raakt, voor HPAIV en LPAIV in verschillende pluimveesoorten berekend. 


\subsection{Methode}

\subsubsection{Verzamelen van literatuur}

Er is een zoekopdracht uitgevoerd in de online database Pubmed. De zoekterm is breed opgezet om geen artikelen te missen en bij het opstellen van de zoektermen is ook de Mesh database van Pubmed gebruikt. De zoektermen waren als volgt:

- ("Inoculation dose" OR "challenge dose" OR "infectious dose") AND "avian influenza" AND "poultry"

("low dose" OR "high dose") AND "avian influenza" AND "poultry"

(((Avian Influenza) AND (Poultry)) AND (Transmission)) AND (High dose)

Met behulp van de 'Pubmed data collection tool' zijn automatisch dubbele referenties verwijderd. Naast de primaire zoekopdracht in Pubmed, is het aantal verzamelde studies uitgebreid door de referenties van studies, die waren geselecteerd na de eerste screening, te screenen op relevante referenties die nog niet aanwezig waren in de dataset. Het verzamelen van literatuur is uitgevoerd door één auteur.

\subsubsection{Screenen van literatuur}

$\mathrm{Na}$ het verzamelen van de literatuur zijn titels en samenvattingen van alle verzamelde papers gescreend op relevantie. Als gevolg van de lage specificiteit van de zoektermen bij het verzamelen van de literatuur was het doel van de eerste screening om snel niet-relevante papers te verwijderen. Voor de eerste screening werden de volgende inclusie criteria gehanteerd:

- De studie is een dier experiment

- De studie is geschreven in het Engels of Nederlands

- De studie is gepubliceerd na 2000

- $\quad$ In de studie zijn meerdere dosissen AIV in pluimvee geïnoculeerd.

Studies die niet voldeden aan de vier inclusie criteria werden niet geselecteerd voor de tweede screening. Wanneer uit de titel en het abstract niet duidelijk was of aan alle inclusie criteria werd voldaan, werden de studies geselecteerd voor de tweede screening. Het doel van de tweede screening was het selecteren van studies met voldoende relevantie en kwaliteit om antwoord te geven op de onderzoeksvraag. Tijdens de tweede screening werd het hele paper bestudeerd. Tijdens de tweede screening werden de volgende inclusie criteria gehanteerd:

- $\quad$ Er is voldaan aan de inclusie criteria van de eerste screening

- De inoculatie dosis kan in verschillende eenheden worden uitgedrukt. Eén daar van is 'Egg Infectious Dose' (EID 50 ). De EID50 wordt bepaald aan de hand van het aantal eieren een virus infecteert tijdens de virusisolatie. De inoculatiedosis moet zijn bepaald in EID 50 .

De screening is uitgevoerd door één auteur, maar bij twijfel is een tweede auteur geraadpleegd.

\subsubsection{Data extractie}

Wanneer een studie aan alle criteria voldeed is de data geëxtraheerd en toegevoegd aan de database. De volgende data is toegevoegd in de dataset: (1) AIVs subtype, (2) AIV pathotype (LPAI of HPAI), (3) oorsprong virus (diersoort), (4) diersoort, (5) specifieke informatie diersoort, (6) leeftijd dier, (7) route inoculatie, (8) inoculatie dosis, (9) aantal geïnfecteerde dieren en (10) totaal aantal dieren die zijn geïnoculeerd. De data extractie is uitgevoerd door één auteur. 


\subsubsection{Data anallyse}

De data is geanalyseerd in $\mathrm{R}$ (versie 3.5.0). Eerst is per diersoort de inoculatie dosis uitgezet tegen het percentage geïnfecteerde dieren, het aantal geïnfecteerde dieren t.o.v. het aantal geïnoculeerde dieren. Hierbij is onderscheid gemaakt tussen LPAIV en HPAIV. Wanneer diverse respiratoire inoculatie routes in de studie waren gecombineerd, zoals 'intranasaal en intratracheaal', 'intranasaal en intrachoanaal' en 'intranasaal, oraal en ocular' zijn deze tijdens de analyse samengevoegd tot "respiratoire inoculatie combi".

Vervolgens is een meta-analyse uitgevoerd waarin de $50 \%$ effectieve dosis, de inoculatie dosis waarbij $50 \%$ van de geïnoculeerde dieren geïnfecteerd raakt, is berekend. Voor de meta-analyse is alleen data van de studies gebruikt waar per diersoort en virus minimaal drie dosissen waren geïnoculeerd en waarbij de laagste dosis niet al direct zorgt voor $100 \%$ geïnfecteerde dieren. Van de geïncludeerde data zijn subsets gecreëerd en elke subset is getest in drie modellen: logit, cloglog en probit model [Faraway, 2004]. Voor elke subset is het best passende model gekozen om de $50 \%$ effectieve dosis te berekenen in EID 50 , de inoculatie dosis waarbij $50 \%$ van de geïnoculeerde dieren geïnfecteerd raakt.

\subsection{Resultaten}

\subsubsection{Verzamelen en screenen van literatuur}

Tabel 8 geeft een overzicht van het verzamelen van de literatuur. Met de opgestelde zoektermen zijn in Pubmed 88 identieke studies verzameld. Tijdens de eerste literatuur screening op titel en samenvatting bleken slechts 30 studies relevant. Tijdens de tweede screening is dit aantal teruggebracht naar 14. Dankzij het doornemen van de referentie lijsten van de studies die tijdens de tweede screening waren geïncludeerd, zijn zes studies extra toegevoegd aan de selectie. In totaal is de data van 20 studies opgenomen in de dataset, waarvan de data van 16 studies zijn gebruikt voor de meta-analyse. Voor een overzicht van de geselecteerde studies, zie bijlage 3 .

Tabel 8 Verzamelen en screenen van literatuur

\begin{tabular}{ll}
\hline Step & Aanial situdies \\
\hline Literatuur verzameling & 110 \\
\hline Deduplicatie & 88 \\
\hline Eerste literatuur screening & 30 \\
\hline Tweede literatuur screening & 14 \\
\hline $\begin{array}{l}\text { Toegevoegd d.m.v. referentielijst } \\
\text { van geselecteerde artikelen }\end{array}$ & 6 \\
\hline In dataset (in meta-analyse) & $\mathbf{2 0 ( 1 6 )}$ \\
\hline
\end{tabular}




\subsubsection{Data analyse}

Figuren 11a en 11b geven per diersoort het percentage geïnfecteerde dieren, het aantal geïnfecteerde dieren t.o.v. het aantal dieren dat is geïnoculeerde dieren, bij de verschillende inoculatie dosissen weer voor respectievelijk HPAIV en LPAIV. De minimale infectieuze dosis van HPAIV is onderzocht in vijf pluimveesoorten: kip, eend, gans, duif en kalkoen. De infectieuze dosis van LPAIV is, naast de vijf diersoorten die zijn onderzocht voor HPAIV, ook onderzocht in kwartels. Van kippen is de meeste data beschikbaar. De laagst onderzochte inoculatie dosis is $0,5 \log _{10}$ EID $_{50}$ (aerosol inoculatie route) en de hoogst onderzochte inoculatie dosis is $8,4 \log _{10} E I_{50}$ (orale inoculatie route).

Uit de figuren blijkt dat het inoculeren van HPAI virussen met een dosis van $\geq 4 \log _{10}$ EID $_{50}$ en het inoculeren van LPAIV met een dosis van $\geq 6 \log _{10}$ EID $_{50}$ in $100 \%$ van de dieren een infectie indiceert. De minimale inoculatie dosis van HPAIV die een infectie indiceert is $2 \log _{10}$ EID $_{50}$ in kippen, ganzen en kalkoenen. Voor LPAIV is de minimale inoculatie dosis die een succesvolle infectie indiceert $1,3 \log _{10}$ EID $_{50}$ voor een aerosol toediening en $2 \log _{10}$ EID $_{50}$ voor andere respiratoire toedieningsroutes. Daarnaast illustreren de figuren dat van sommige virussen een hogere inoculatie dosis moet worden toegediend dan voor andere virussen om hetzelfde percentage dieren te infecteren. Dit is bijvoorbeeld waarneembaar in ganzen: het HPAI H5N2 virus was bij een inoculatie dosis $10^{2} \log _{10}$ EID 50 niet in staat om dieren te infecteren, echter het gebruikte HPAI H5N8 virus infecteerde met dezelfde dosis $100 \%$ van de ganzen. Het verschil in minimale inoculatie dosis is ook waarneembaar bij virussen van hetzelfde subtype bijvoorbeeld bij de H5N2 virussen in kalkoenen. Over het algemeen geldt dat hoe hoger de inoculatie dosis, hoe groter het percentage geïnfecteerde dieren.

De resultaten van de meta-analyse, waarin de $50 \%$ effectieve dosis, de inoculatie dosis waarbij $50 \%$ van de geïnoculeerde dieren geïnfecteerd raakt, is berekend voor verschillende HPAIV en LPAIV, zijn weergegeven in tabel 11. HPAIV hebben in kippen bij een intranasale of intrachoanale toediening gemiddeld een lagere $50 \%$ effectieve dosis dan LPAIV, dus kippen hebben gemiddeld minder HPAIV dan LPAIV nodig om geïnfecteerd te raken met AI. Kippen hebben van alle pluimvee soorten de laagste $50 \%$ effectieve dosis voor HPAIV: in de modellen is berekend dat in twee studies vijftig procent van de kippen al geïnfecteerd raakt met HPAIV bij dosissen van $1.71 \log _{10}$ EID 50 (0.71-2.86) en $2.17 \log _{10}$ EID $_{50}$ (1.13-3.26). De pekingeenden en de gans hebben een lagere 50\% effectieve dosis dan de kalkoenen en de duif voor HPAIV. De data in de kippen lijkt een trend te tonen dat HPAIV die geïsoleerd zijn uit pluimvee (kip en kalkoen) een lagere $50 \%$ effectieve dosis hebben dan virussen die zijn geïsoleerd uit wilde vogels of de mens. 
a)

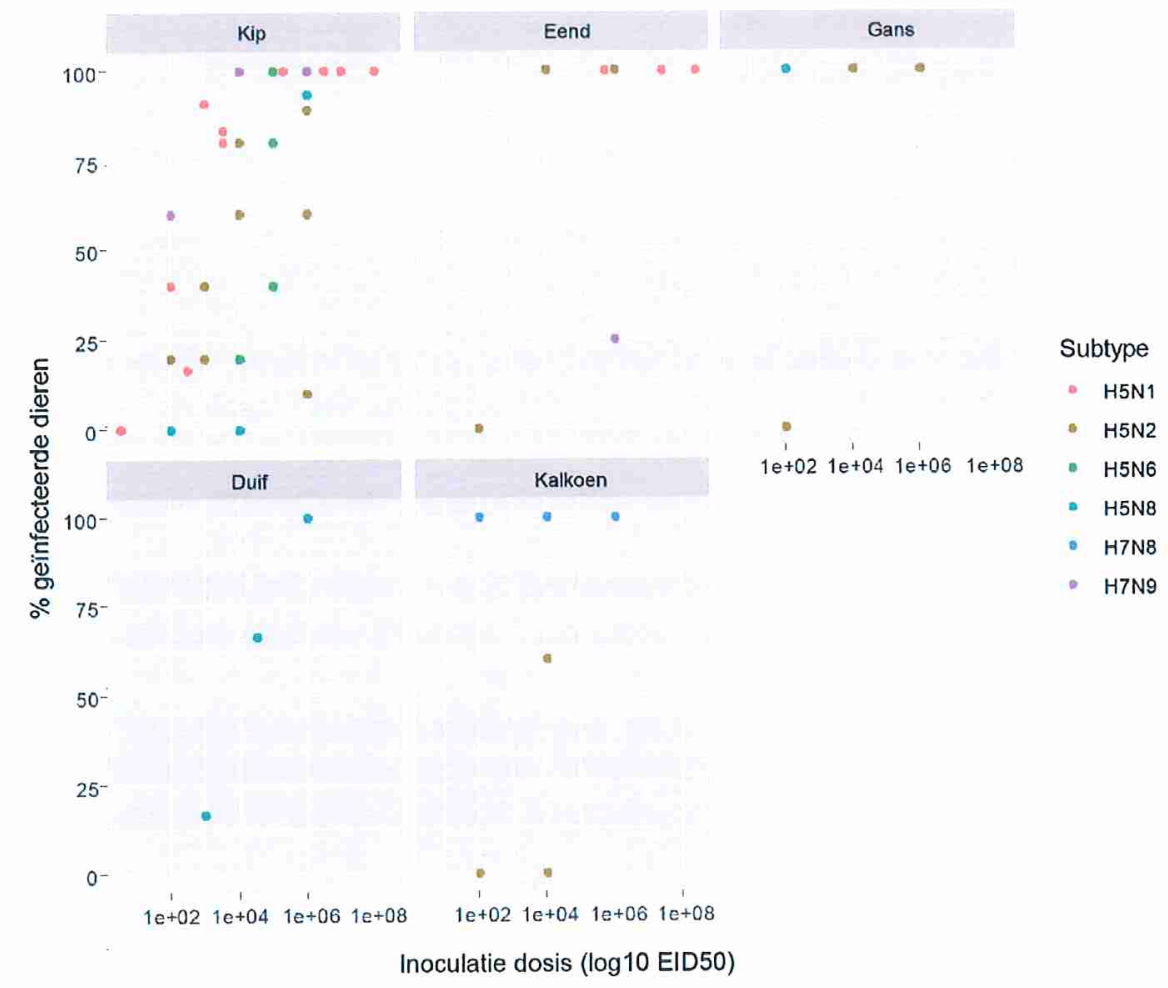

b)

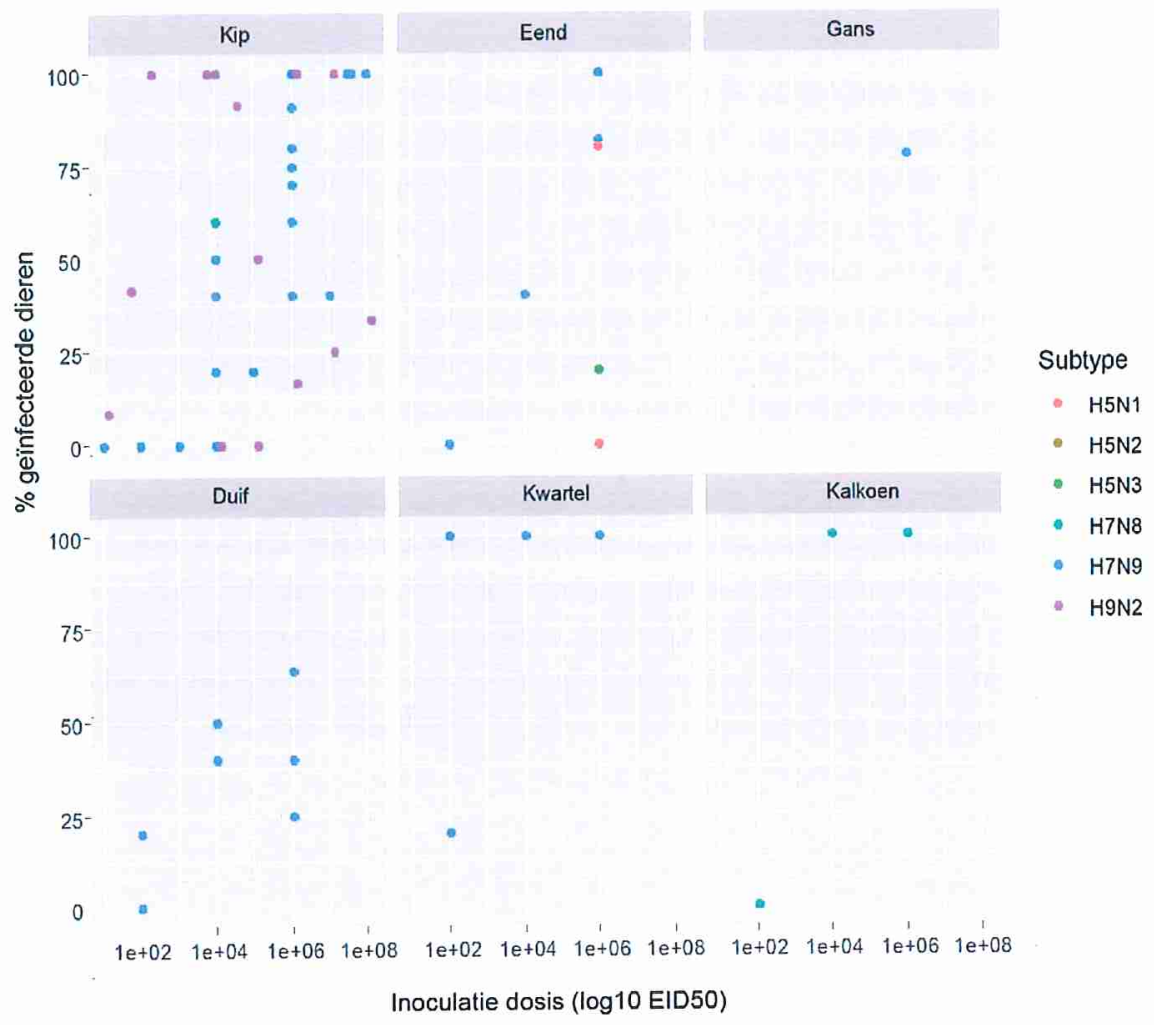

Figuur 11 Het percentage geïnfecteerde dieren met verschillende subtype a) HPAIV en b) LPAIV met verschillende inoculatie dosis $\left(\log _{10} \mathrm{EID}_{50}\right)$. 
Bij LPAIV hebben kalkoenen en kwartels een lagere 50\% effectieve dosis dan kippen en eenden, ondanks dat de oorsprong van het virus dat is geïnoculeerd bij de kwartel van de mens is.

\subsection{Conclusie}

- De minimale inoculatie dosis die nodig is voor het indiceren van een infectie is voor HPAIV $2 \log _{10}$ EID $_{50}$ in kippen, ganzen en kalkoenen en voor LPAIV $2 \log _{10}$ EID $_{50}$ in kippen via respiratoire toedieningsroutes.

- Over het algemeen geldt: hoe hoger de inoculatie dosis, hoe groter het percentage geïnfecteerde dieren. Echter, de minimale of $50 \%$ effectieve inoculatie dosis verschilt per virus (ook van virussen binnen hetzelfde subtype).

- HPAIV hebben gemiddeld een lagere 50\% effectieve dosis dan LPAIV. Dit betekent dat HPAIV in staat zijn om met een lagere dosis virus dan LPAIV nodig heeft, de helft van een koppel succesvol te kunnen infecteren.

- Kippen hebben t.o.v. andere pluimveesoorten de laagste 50\% effectieve dosis voor HPAIV.

- De data in de kippen lijkt een trend te tonen dat HPAIV die geïsoleerd zijn uit pluimvee een lagere 50\% effectieve dosis hebben dan virussen die zijn geïsoleerd uit wilde vogels of de mens.

\subsection{Discussie}

Uit de analyse kan worden geconcludeerd dat HPAIV een lagere infectieuze dosis hebben dan LPAIV. Echter, het blijkt dat verschillende virussen, ook binnen dezelfde subtypes, verschillende minimale inoculatie dosissen en $50 \%$ effectieve dosissen indiceren. Er kan aan de hand van de analyse dus geen antwoord worden gegeven op de vraag of een bepaald subtype virus in het algemeen een lagere minimale inoculatie dosis nodig heeft dan een ander subtype. Wanneer virussen genetisch zeer nauw verwant zijn is het mogelijk dat de minimale inoculatie dosis en $50 \%$ effectieve dosis van deze virussen gelijk zijn. Echter, in deze analyse is dit niet onderzocht, omdat er onvoldoende virussen van hetzelfde subtype in de database aanwezig waren om deze onderzoeksvraag te kunnen beantwoorden.

De verzamelde data voor pluimveesoorten anders dan kippen was summier. Daardoor is het niet mogelijk om pluimveesoort overschrijdende conclusies te trekken anders dan dat kippen ten opzichte van andere pluimveesoorten een lagere 50\% effectieve dosis hebben voor HPAIV. Tot slot, was er slechts één studie die virus heeft toegediend via aerosolen waardoor ook dit aspect niet voldoende onderzocht kon worden. Kortom, een soortgelijke analyse zal in de toekomst, wanneer meer bruikbare publicaties zijn verschenen, nog een keer uitgevoerd moeten worden om meer data te genereren om ook bovenstaande vragen te kunnen beantwoorden. 


\section{Referenties}

Quinn, P.J., Markey, B.K., Carter, M.E., Donnelly, W.J., Leonard, F.C. Pathogenesis of viral diseases, in Veterinary Microbiology and Microbial Disease. 2002, Blackwell Publishing: Padstow, Cornwall, Great Britain. p. 301-304.

Cornelissen, J.B. et al. Differential innate responses of chickens and ducks to low-pathogenic avian influenza. Avian Pathol. 2012; 41(6): 519-29.

Post, J. et al. Systemic virus distribution and host responses in brain and intestine of chickens infected with low pathogenic or high pathogenic avian influenza virus. Virology Journal 2012; 9: 61-71.

Pantin-Jackwood, M.J. et al. The pathogenesis of H7N8 low and highly pathogenic avian influenza viruses from the United States 2016 outbreak in chickens, turkeys and mallards. PloS ONE 2017; 12(5): e0177265.

Faraway, J. Chapter 2 Binomial Data, in Linear models with R. Generalized Linear, Mixed Effects and Nonparametric Regression Models. 2004, Hall/CRC: Boca Raton: 28-60. 


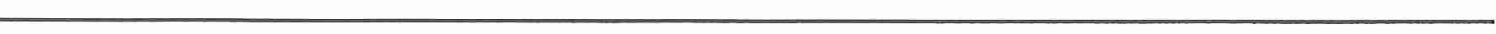




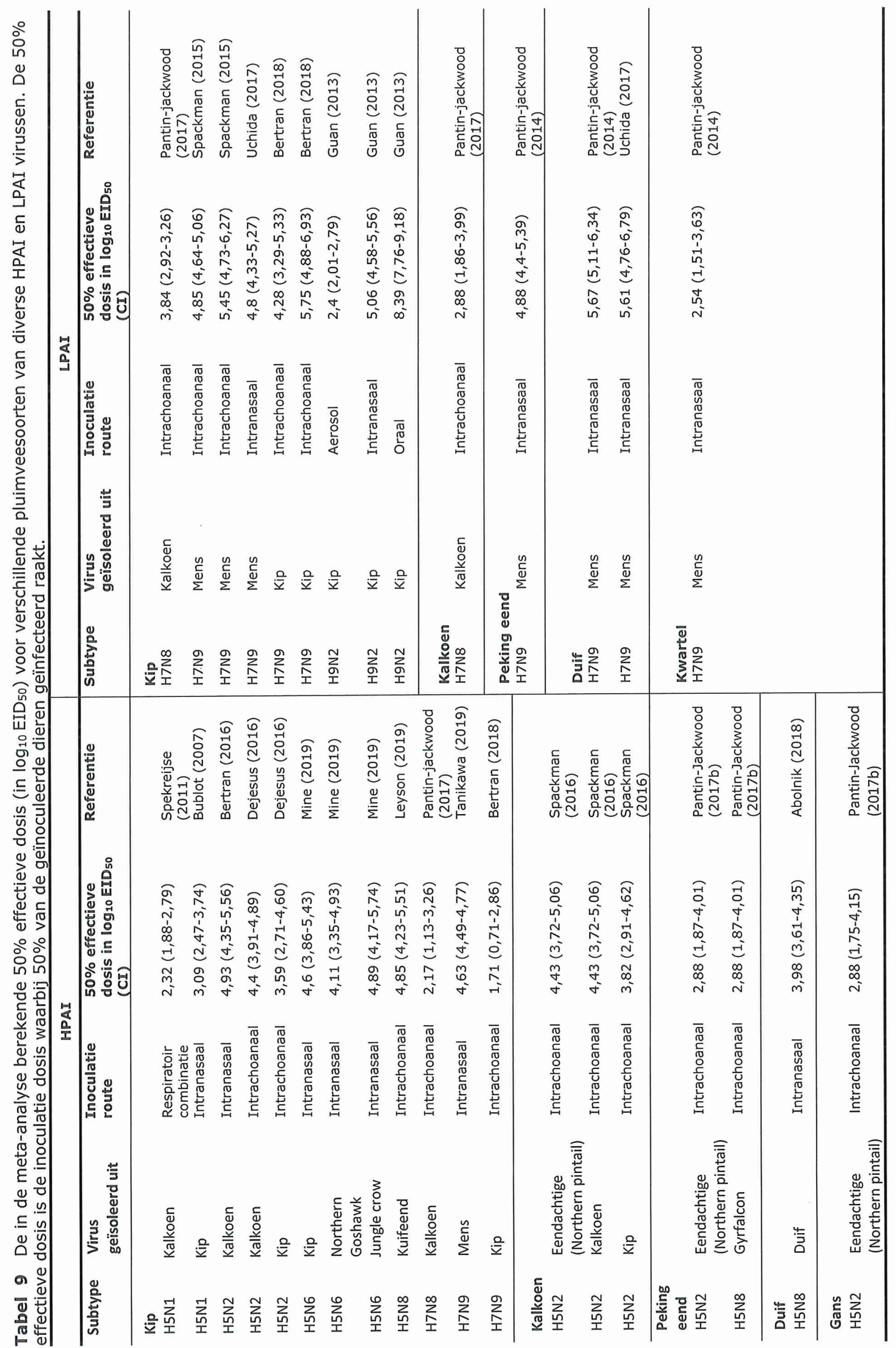




\section{Pluimveehouder redenering "virus via luchtinlaat binnen gekomen" in perspectief geplaatst}

Tijdens de uitbraken met HPAIV subtype H5N8 in 2016, 2017-2018 en 2020 hebben enkele pluimveehouders aangegeven dat verhoogde sterfte bij pluimvee begonnen zou zijn bij - of dicht in de buurt van - de luchtinlaat van de pluimveestal [Velkers et al., 2017; 2018; artikelen in vakbladen]. Voor sommige pluimveehouders is het logisch te denken dat aviaire influenza virus (AI) virus daarom via de luchtinlaat binnen zou zijn gekomen omdat men onwillekeurig een directe relatie legt tussen het optreden van de sterfte en de plaats en tijd waar de sterfte wordt gezien. Dat men die correlatie maakt komt waarschijnlijk omdat men de achtergrond niet kent van het tijdsverloop van een infectie met HPAIV in een koppel dieren en het optreden van sterfte na infectie.

Tussen de observatie van verhoogde sterfte van pluimvee bij - of dicht in de buurt van- de luchtinlaat en de plaats en tijd waar het virus voor het eerst echt zijn intrede heeft gedaan in de stal bestaat echter geen direct, oorzakelijk verband. Van de meeste HPAI-introducties in de afgelopen jaren is het moment van virusintroductie geschat met één van de door WBVR ontwikkelde EpiTools modules [Hobbelen et al., 2020]. Daaruit komt naar voren dat de daadwerkelijke virus-introductie in een stal naar schatting gemiddeld ruim meer dan een week vóór het moment ligt dat er duidelijk verhoogde sterfte wordt gezien in de stal. Dat betekent ook dat gebeurtenissen - één tot enkele dagen voorafgaande aan de verhoogde sterfte zoals sterke wind of dichte mist die op de stal heeft gestaan aan de kant van luchtinlaat - die pluimveehouders soms noemen als veronderstelde oorzaak, geen oorzakelijke relatie kunnen hebben met de introductie van het virus in de stal.

Het is daarom onwaarschijnlijk dat een aantal individuele dieren die bij - of dicht in de buurt van - een luchtinlaat zouden zijn besmet, de besmetting doorgeven aan andere dieren en dat minimaal een week later afzonderlijke besmette dieren weer bij elkaar bij - of dicht in de buurt van - een luchtinlaat zouden zijn en daar sterven. Dat is op basis van kansrekening niet logisch gezien het grote tijdsverschil tussen besmetting en het waarnemen van de verhoogde sterfte.

Een, in ons opzicht, aannemelijkere verklaring voor het waarnemen van de start van de verhoogde sterfte bij individuele dieren die zich bevinden bij - of dicht in de buurt van - een luchtinlaat is dat HPAIV-geïnfecteerde dieren merendeels ernstige luchtwegproblemen hebben met ademnood. Het is aannemelijk dat dieren met ademnood op zoek gaan naar verse/frisse lucht, die in grotere mate aanwezig zal zijn bij - of dicht in de buurt van - een luchtinlaat, en zich daarom naar deze locaties binnen de stal verplaatsen.

\section{Referenties}

Hobbelen, P.H.F., Elbers, A.R.W., Werkman, M., Koch, G., Velkers, F.C., Stegeman, J.A., Hagenaars, T.J., Estimating the introduction time of highly pathogenic avian influenza into poultry flocks. Sci. Rep. 2020; 10: 12388. https://doi.org/10.1038/s4159 8-020-68623 -w.

Velkers, F.C., Manders, T.T.M., Beerens, N., Elbers, A.R.W., Bouwstra, R.J., Stegeman, J.A. Vogelgriep in Nederland. Analyse H5N8 uitbraken in 2016. Rapport Fac. Diergeneeskunde, Univ. Utrecht. 63 pp.

Velkers, F.C., Manders, T.T.M., Beerens, N., Elbers, A.R.W., Bouwstra, R.J., Stegeman, J.A. Analyse vogelgriepuitbraken met HPAI H5N6 in Nederland in 2017-2018. Rapport Fac. Diergeneeskunde, Univ. Utrecht. $28 \mathrm{pp}$. 
Artikelen in vakbladen:

https://www.forfarmersinnovatiefonds.nl/innovaties/innovaties/windbreekgaas_voor_de_inlaatopening en_van_een_leghennenstal.aspx

https://www.pluimveeactueel.nl/nieuwsartikel/2017/innovatieprijs-voor-windbreekgaas-tegenvogelgriep/b24g18c29o1898/

https://www.boerderij.nl/Pluimveehouderij/Achtergrond/2018/5/Pluimveestallen-hermetisch-dichttegen-vogelgriep-278830E/

https://www.boerderij.nl/Pluimveehouderij/Achtergrond/2019/4/Windbreekgaas-verlaagtbesmettingsdruk-AI-413931E/

https://www.pluimveeweb.nl/artikel/385100-vogelgriep-waarschijnlijk-via-ventilatie-binnengekomen/ 


\title{
10 Semi-kwantitatieve risicoanalyse transmissie van (HP)AIV door de lucht van wilde watervogel naar pluimveestal
}

\author{
10.1 Inleiding
}

In dit rapport zijn de benodigde bouwstenen voor een eventueel uit te voeren kwantitatieve risicoanalyse bijeen gebracht, gericht op de kwantificering van het risico op insleep van (HP)AIV, met een focus op mogelijke transmissie via de lucht:

i) (HP)AIV gehecht aan vervliegbare meststofdeeltjes van wilde watervogels via luchttransport door de luchtinlaat van een pluimveestal naar vatbaar pluimvee;

ii) (HP)AIV in een aerosol - met als bron proesten of uitademing van geïnfecteerde wilde watervogels - via luchttransport door de luchtinlaat van een pluimveestal naar vatbaar pluimvee.

Om inzicht te krijgen of het zinvol is om een uitgebreide kwantitatieve risicoanalyse uit te voeren, wordt meestal eerst een kwalitatieve of semi-kwantitatieve risicoanalyse uitgevoerd. Als namelijk op basis van de kwalitatieve/semi-kwantitatieve risicoanalyse blijkt dat het ingeschatte risico verwaarloosbaar is, dan heeft een uitgebreide kwantitatieve risicoanalyse geen toegevoegde waarde meer. Voor de semikwantitatieve risicoanalyse hebben we daarom voor de twee bovengenoemde transmissieroutes een flowchart gemaakt met daarin de verschillende stappen voor beide routes.

\subsection{Flowchart - (HP)AIV gehecht aan vervliegbare meststof- deeltjes van wilde watervogels via luchttransport naar pluimveestal}

In de navolgende flowchart worden de verschillende stappen weergegeven van het transmissie-proces met betrekking tot (HP)AIV gehecht aan vervliegbare meststofdeeltjes van wilde watervogels via luchttransport door de luchtinlaat van een pluimveestal naar vatbaar pluimvee. De uiteindelijke dosis van HPAIV dat gehecht aan vervliegbare meststofdeeltjes van wilde watervogels via luchttransport naar de pluimveestal wordt getransporteerd en pluimvee aanwezig in de pluimveestal zou kunnen infecteren is het wiskundige product van de afzonderlijke kansen en geschatte concentraties van HPAIV van de verschillende stappen: $5 * 10^{-4}$ (stap A) x $500 * 6 * 10^{8}$ (stap B en C) x $10^{-6}$ (stap D) $\times 10^{-6}$ (stap E) $\times 0.75 \times 10^{-5}$ tot $10^{-20}$ (afhankelijk van afstand tot de kippen in de stal; stap G). De orde van grootte van de geschatte HPAIV dosis komt dan uit op ca. $10^{-9}$ tot $10^{-24}$ EID $_{50}$ (ter illustratie: $10^{-9}$ betekent 1 per miljard), terwijl de minimale inoculatie dosis voor infectie met HPAIV bij pluimvee $10^{2}$ EID $_{50}$ is. De geschatte HPAIV dosis is zo verwaarloosbaar klein dat het niet de moeite waard is om in overweging te worden genomen. Dit betekent ook dat het uitvoeren van een uitgebreide kwantitatieve risicoanalyse geen zin heeft. 
A. HPAIV Prevalentie wilde vogels: 5 per 10.000 wilde watervogels
B. Wilde eenden en ganzen poepen gemiddeld $50 \mathrm{keer} /$ dag op het land; gemiddeld gewicht wilde eendenmest: 2,2 gram; gemiddeld gewicht ganzenmest: 8,3 gram. Dat betekent gemiddeld ca. $100 \mathrm{gram} /$ dag Wilde eendenmest en ca. $500 \mathrm{gram} /$ dag ganzenmest
D. Verdrogen wilde vogelmest in vogelgriep-risicoperiode zodat het kan vervliegen. Kans is verwaarloosbaar klein ( 1 per $10^{6}$ )
E. Levensvatbaarheid AIV na verdrogen mest. Kans op overleving AIV in verdroogde mest die kan vervliegen is verwaarloosbaar klein ( 1 per $10^{6}$ )
C. LPAIV uitscheiding in Wilde eendenmest: ca. 6 dagen met $10^{7}-10^{8}$ EID 50 per gram mest; onbekend voor HPAIV

F. Inactivatie van AIV tijdens mogelijk transport door de lucht; tijdens okt. - mrt periode met hoge relatieve vochtigheid (o.a. ook mist) zal inactivatie aanzienlijk zijn (25-50\% inactivitatie)

G. Verdunning AIV - na loslaten bij een puntbron in de lucht op weg naar kippen in de stal: verdunningsfactor $10^{5}$ op 30 meter afstand, verdunningsfactor $10^{20}$ op 50 meter afstand

\subsection{Flowchart - (HP)AIV in een aerosol via luchttransport naar pluimveestal}

In de navolgende flowchart worden de verschillende stappen weergegeven van het transmissie-proces met betrekking tot AIV in een aerosol - met als bron proesten of uitademing van geïnfecteerde wilde watervogels - via luchttransport door de luchtinlaat van een pluimveestal naar vatbaar pluimvee. 
A. HPAIV Prevalentie wilde vogels: 5 per 10.000 wilde vogels
B. HPAIV uitscheiding via uitademing en proesten; luchtmonsters van de experimentele ruimte tijdens een HPAIVinfectie experiment in kippen (initiële infectie dosis $10^{5}$ EID50) bevatte lage HPAIV-concentraties (slechts $10 \%$ van de lucht monsters positief met concentratie 101.3-1.6 EID50)
D. Verdunning AIV -na loslaten bij een puntbron - in een aerosol bij transport door de lucht op weg naar kippen in de stal: verdunningsfactor $10^{5}$ op 30 meter afstand, verdunningsfactor $10^{20}$ op 50 meter afstand
C. Inactivatie van AIV in aerosol tijdens mogelijk transport door de lucht: tijdens okt. - mrt periode met hoge relatieve vochtigheid (o.a. ook mist) zal inactivatie aanzienlijk zijn (25 - 50\%)

De uiteindelijke dosis van (HP)AIV (uitgeademd of geproest door besmette wilde vogels) die in een aerosol via luchttransport de stal zou kunnen bereiken, is het wiskundige product van de afzonderlijke kansen en geschatte concentraties van HPAIV van de verschillende stappen: $5 * 10^{-4}(\operatorname{stap} \mathrm{A}) \times 10^{-1} *$ $10^{2}$ (stap B) $\times 0.75 \times 10^{-5}$ tot $10^{-20}$ (afhankelijk van afstand tot de kippen in de stal; stap C en D). De orde van grootte van de geschatte HPAIV dosis komt dan uit op ca. $10^{-8}$ tot $10^{-23}$ EID 50 (ter illustratie: $10^{-8}$ betekent 1 per 100 miljoen), terwijl de minimale inoculatie dosis voor infectie met HPAIV bij pluimvee $10^{2}$ EID 50 is. De geschatte HPAIV dosis is zo verwaarloosbaar klein dat het niet de moeite waard is om in overweging te worden genomen. Dit betekent ook dat het uitvoeren van een uitgebreide kwantitatieve risicoanalyse geen zin heeft.

\subsection{Conclusie}

- De orde van grootte van de geschatte dosis van (HP)AIV gehecht aan vervliegbare meststofdeeltjes van wilde watervogels die via luchttransport door de luchtinlaat van een pluimveestal bij vatbaar pluimvee zou kunnen komen is ca. $10^{-10}$ tot $10^{-25}$ EID 50 , terwijl de minimale inoculatie dosis voor infectie met HPAIV bij pluimvee $10^{2}$ EID50 is. De geschatte (HP)AIV dosis voor deze introductieroute is zo verwaarloosbaar klein dat het niet de moeite waard is om in overweging te worden genomen. Dit betekent ook dat het uitvoeren van een uitgebreide kwantitatieve risicoanalyse geen zin heeft.

- De orde van grootte van de geschatte dosis van (HP)AIV die in een aerosol (door uitgeademde lucht of proesten van een besmette wilde vogels) via luchttransport door de luchtinlaat van een pluimveestal bij vatbaar pluimvee zou kunnen komen is ca. $10^{-8}$ tot $10^{-23}$ EID 50 , terwijl de minimale inoculatie dosis voor infectie met HPAIV bij pluimvee $10^{2}$ EID 50 is. De geschatte (HP)AIV dosis voor deze introductieroute is zo verwaarloosbaar klein dat het niet de moeite waard is om in overweging te worden genomen. Dit betekent ook dat het uitvoeren van een uitgebreide kwantitatieve risicoanalyse geen zin heeft. 


\section{Algemene conclusies}

- De semi-kwantitatieve risicoanalyse laat zien dat het risico op aerogeen transport van vogelgriepvirus vanuit

b) vervliegbare wilde watervogelmest in de omgeving van de pluimveestal (zoals grasweiden, verharding rondom de stal);

b) een aerosol geproduceerd door uitademen of proesten van HPAIV-besmette wilde watervogels

die via de luchtinlaat in de pluimveestal zou kunnen komen, als verwaarloosbaar klein moet worden beschouwd. Voor deze mogelijke AIV-introductieroutes zijn er daarom geen wetenschappelijke argumenten om daarvoor een afscherming van de luchtinlaten in de vorm van filters (b.v. een hepafilter of mogelijk windbreekgaas) aan te bevelen.

- Veren van HPAIV-besmette wilde vogels bevatten HPAIV. HPAIV in veren is persistent: het virus persisteert minimaal 34 dagen bij $4^{\circ} \mathrm{C}$ en veel langer bij lagere temperaturen. Veren van HPAIV-besmette wilde vogels zouden vrij kunnen komen als aaseters aan karkassen eten en mogelijk met de wind naar de omgeving en mogelijk door de luchtinlaat van pluimveestallen kunnen worden vervoerd. Basale gegevens over de mate waarin dit zou kunnen gebeuren ontbreken echter. Daarom kan er geen onderbouwde risicoanalyse worden uitgevoerd, het blijft bij een theoretische mogelijkheid (net als overigens een hoop andere mogelijke introductieroutes).

Uit voorzorg zou men kunnen aangeven dat het belangrijk is dat karkassen van dode, met HPAIV-besmette wilde (water)vogels zo spoedig mogelijk na sterfte uit de natuurlijke omgeving worden opgeruimd omdat zij de bron zouden kunnen zijn van losse veren. 


\section{Dankwoord}

Wij danken Roy Slaterus, werkzaam bij Stichting Vogelonderzoek Nederland Sovon (Nijmegen), voor hulp bij het lokaliseren van de Smienten in de Nekkeveldpolder bij Nijkerk om de smientenmest te kunnen verzamelen. 


\section{Bijlage 1 Samenvatting van het systematische review protocol hoofdstuk 4}

\begin{tabular}{ll}
\hline Onderzoeksvraag & Hoe lang persisteert AIV in de omgeving? \\
\hline Zoek data & $>1975-26$ februari 2020 \\
\hline Language & Engels en Nederlands \\
\hline Publicatie type & $\begin{array}{l}\text { Peer reviewed studies: experimenten met als onderwerp AIV persistentie } \\
\text { in de omgeving of op producten van pluimvee/vogels } \\
\text { Ongepubliceerde experimenten met als onderwerp AIV persistentie in de } \\
\text { omgeving of op producten van pluimvee/vogels }\end{array}$ \\
\hline Populatie & $\begin{array}{l}\text { Omgeving: water, aarde, oppervlaktes van materialen die op een } \\
\text { commercieel bedrijf mogelijk in aanraking kunnen komen met virus. }\end{array}$ \\
& $\begin{array}{l}\text { Producten van pluimvee: mest, veren, stuitklierolie, eieren. } \\
\text { Het AIV is afkomstig van pluimvee onafhankelijk van leeftijd. } \\
\text { "Pluimvee" is gedefinieerd als: alle vogels die worden gehouden in } \\
\text { gevangenschap voor vlees of eiconsumptie, produceren van andere } \\
\text { producten, voor het fokken van nakomelingen of voor hobbydieren, inclusief } \\
\text { kippen, eenden, kwartels, ganzen, kalkoenen, fazanten, hoenders, patrijzen, } \\
\text { zwanen, struisvogels en duiven. }\end{array}$ \\
\hline $\begin{array}{l}\text { HPAIV en LPAIV van alle subtypes } \\
\text { De AIV persistentie is bepaald met behulp van virus/ei isolatie, dus geen } \\
\text { (rt-)PCR, en mag zijn doorgerekend met een lineair regressiemodel } \\
\text { De AIV persistentie moet zijn uitgedrukt in aantal dagen of het aantal } \\
\text { dagen moet af te leiden zijn uit de resultaten } \\
\text { Wanneer de AIV persistentie is bepaald in water, moet de persistentie zijn } \\
\text { bepaald in natuurlijk oppervlakte water }\end{array}$ \\
\hline AI virussen
\end{tabular}




\section{Bijlage 2 Geselecteerde studies hoofdstuk 5}

Mihai, M.E. et al., Survival of H5N1 influenza virus in water and its inactivation by chemical methods. Roum. Arch. Microbiol. Immunol. 2011; 70(2): 78-84.

Webster, R.G. et al. Intestinal influenza: replication and characterization of influenza viruses in ducks. Virology 1978; 84(2): 268-278.

Zhang, $\mathrm{H}$. et al. Perpetuation of H5N1 and H9N2 avian influenza viruses in natural water bodies. J Gen Virol. 2014; 95(7): 1430-1435.

Nielsen, A.A., et al., Persistence of low-pathogenic H5N7 and H7N1 avian influenza subtypes in filtered natural waters. Vet. Microbiol. 2013; 166(3-4): 419-28.

Zarkov, I.S. Survival of avian influenza viruses in filtered and natural surface, waters of different physical and chemical parameters. Rev. Med. Vet. 2006; 157(10): 471-476.

Dovas, C.I. et al. Detection and quantification of infectious avian influenza A (H5N1) virus in environmental water by using real-time reverse transcription-PCR. Appl. Environ. Microbiol. 2010; 76(7): 2165-2174.

Nazir, J. et al. Long-term study on tenacity of avian influenza viruses in water (distilled water, normal saline, and surface water) at different temperatures. Avian Dis. 2010; 54(1 Suppl): 720-4.

Nazir, J. et al. Persistence of Avian Influenza Viruses in Lake Sediment, Duck Feces, and Duck Meat. Appl. Environ. Microbiol. 2011; 77(14): 4981-4985.

Keeler, S.P., Lebarbenchon, C., Stallknecht, D.E. Strain-related variation in the persistence of influenza A virus in three types of water: distilled water, filtered surface water, and intact surface water. Virology J. 2013; 10: 13-23.

Horm, S.V. et al. Environment: a potential source of animal and human infection with influenza A (H5N1) virus. Influenza Other Respir. Viruses 2012; 6(6): 442-8.

Domanska-Blicharz, K. et al. H5N1 high pathogenicity avian influenza virus survival in different types of water. Avian Dis. 2010; 54(1 Suppl): 734-7.

Koch, G., FLURESIST: Studies on Avian Influenza Virus Survival in Poultry Commodities, Poultry Manure and the Environment. 2011.

Lu, H. et al. Survival of Avian Influenza Virus H7N2 in SPF Chickens and Their Environments. Avian Dis. $2003 ; 47$ : 1015-1021.

Guan, J. et al. Survival of avian influenza and Newcastle disease viruses in compost and at ambient temperatures based on virus isolation and real-time reverse transcriptase PCR. Avian Dis. 2009; 53(1): 26-33.

Kurmi, B. et al, Survivability of Highly Pathogenic Avian Influenza H5N1 Virus in Poultry Faeces at Different Temperatures. Indian J. Virol. 2013; 24(2): 272-277.

Yamamoto, Y. et al. Persistence of avian influenza virus (H5N1) in feathers detached from bodies of infected domestic ducks. Appl. Environ. Microbiol. 2010; 76(16): 5496-5499.

Yamamoto, Y., Nakamura, K., Mase, M. Survival of Highly Pathogenic Avian Influenza H5N1 Virus in Tissues Derived from Experimentally Infected Chickens. Appl. Environ. Microbiol. 2017; 83(16): e00604-17.

Busquets, N. et al. Persistence of highly pathogenic avian influenza virus (H7N1) in infected chickens: feather as a suitable sample for diagnosis. J. Gen. Virol. 2010; 91(9): 2307-13.

Karunakaran, A.C. et al. Survivability of highly pathogenic avian influenza virus (H5N1) in naturally preened duck feathers at different temperatures. Transbound. Emerg. Dis. 2019; 66(3): 13061313.

Tiwari, A. et al. Survival of two avian respiratory viruses on porous and nonporous surfaces. Avian Dis. 2006; 50(2): 284-7.

Delogu, M. et al. Italian human and animal integrated influenza surveillance: Human and animal integrated influenza surveillance: a novel sampling approach for an additional transmission way in the aquatic bird reservoir. Italian Journal of Public Heath 2012; 9: 29-36.

Wood, J.P. et al. Environmental persistence of a highly pathogenic avian influenza (H5N1) virus. Environ. Sci. Technol. 2010; 44(19): 7515-20. 


\section{Bijlage 3 Geselecteerde studies hoofdstuk 8}

Abolnik, C., Stutchbury, S., Hartman, M.J. Experimental infection of racing pigeons (Columba livia domestica) with highly pathogenic Clade 2.3.4.4 sub-group B H5N8 avian influenza virus. Vet. Microbiol. 2018; 227: 127-132.

Bertran, K., et al. Age is not a determinant factor in susceptibility of broilers to H5N2 clade 2.3.4.4 high pathogenicity avian influenza virus. Vet. Res. 2016; 47(1): 116.

Bertran, K. et al. Pathobiology of Tennessee 2017 H7N9 low and high pathogenicity avian influenza viruses in commercial broiler breeders and specific pathogen free layer chickens. Vet. Res. 2018; 49(1): 82-82.

Bublot, M. et al. Efficacy of a fowlpox-vectored avian influenza H5 vaccine against Asian H5N1 highly pathogenic avian influenza virus challenge. Avian Dis. 2007; 51(1 Suppl): 498-500.

DeJesus, E., et al. Changes in adaptation of H5N2 highly pathogenic avian influenza H5 clade 2.3.4.4 viruses in chickens and mallards. Virology 2016; 499: 52-64.

Guan, J. et al. Aerosol transmission of an avian influenza H9N2 virus with a tropism for the respiratory tract of chickens. Avian Dis. 2013; 57(3): 645-649.

Kariithi, H.M. et al, Genetic characterization and pathogenesis of the first H9N2 low pathogenic avian influenza viruses isolated from chickens in Kenyan live bird markets. Infect. Genet. Evol. 2020; 78: 104074.*

Leyson, C. et al. Pathogenicity and genomic changes of a 2016 European H5N8 highly pathogenic avian influenza virus (clade 2.3 .4 .4 ) in experimentally infected mallards and chickens. Virology 2019; 537: 172-185.

Liu, K., et al. Genetic and biological characterization of two reassortant H5N2 avian influenza A viruses isolated from waterfowl in China in 2016. Vet. Microbiol. 2018; 224: 8-16.*

Mine, J., et al. Genetics and pathogenicity of H5N6 highly pathogenic avian influenza viruses isolated from wild birds and a chicken in Japan during winter 2017-2018. Virology 2019; 533: 1-11.

Nuradji, $H_{\text {., }}$ et al. A comparative evaluation of feathers, oropharyngeal swabs, and cloacal swabs for the detection of H5N1 highly pathogenic avian influenza virus infection in experimentally infected chickens and ducks. J. Vet. Diagn. Invest. 2015; 27(6): 704-15.*

Pantin-Jackwood, M.J., et al. Role of poultry in the spread of novel H7N9 influenza virus in China. J. Virol. 2014; 88(10): 5381-5390.

Pantin-Jackwood, M.J., et al. The pathogenesis of H7N8 low and highly pathogenic avian influenza viruses from the United States 2016 outbreak in chickens, turkeys and mallards. PLoS ONE 2017; 12(5): e0177265.

Pantin-Jackwood, M.J. et al. Infectivity, transmission and pathogenicity of H5 highly pathogenic avian influenza clade 2.3.4.4 (H5N8 and H5N2) United States index viruses in Pekin ducks and Chinese geese. Vet. Res. 2017; 48(1): 33.

Ridenour, C. et al, Serial passage in ducks of a low-pathogenic avian influenza virus isolated from a chicken reveals a high mutation rate in the hemagglutinin that is likely due to selection in the host. Arch. Virol. $2015 ; 160(10)$ : 2455-2470.*

Spackman, E. et al., Impact of route of exposure and challenge dose on the pathogenesis of H7N9 low pathogenicity avian influenza virus in chickens. Virology 2015; 477: 72-81.

Spackman, E. et al. H5N2 Highly Pathogenic Avian Influenza Viruses from the US 2014-2015 outbreak have an unusually long pre-clinical period in turkeys. BMC Vet. Res. 2016; 12(1): 260.

Spekreijse, D. et al. The effect of inoculation dose of a highly pathogenic avian influenza virus strain H5N1 on the infectiousness of chickens. Vet. Microbiol. $2011 ; 147(1-2): 59-66$.

Tanikawa, T. et al. Pathogenicity of two novel human-origin H7N9 highly pathogenic avian influenza viruses in chickens and ducks. Arch. Virol. 2019; 164(2): 535-545.

Uchida, Y. et al. Susceptibility of chickens, quail, and pigeons to an H7N9 human influenza virus and subsequent egg-passaged strains. Arch. Virol. 2017; 162(1): 103-116.

* data van deze studie is niet gebruikt in de meta-analyse 

Wageningen Bioveterinary Research Postbus 65

$8200 \mathrm{AB}$ Lelystad

T 0320238238

info.bvr@wur.nl

www.wur.nl/bioveterinary-research

Wageningen Bioveterinary Research
De missie van Wageningen University \& Research is 'To explore the potential of nature to improve the quality of life'. Binnen Wageningen University \& Research bundelen Wageningen University en gespecialiseerde onderzoeksinstituten van Stichting Wageningen Research hun krachten om bij te dragen aan de oplossing van belangrijke vragen in het domein van gezonde voeding en leefomgeving. Met ongeveer 30 vestigingen, 5.000 medewerkers en 12.000 studenten behoort Wageningen University \& Research wereldwijd tot de aansprekende kennisinstellingen binnen haar domein. De integrale benadering van de vraagstukken en de samenwerking tussen verschillende disciplines vormen het hart van de unieke Wageningen aanpak. 